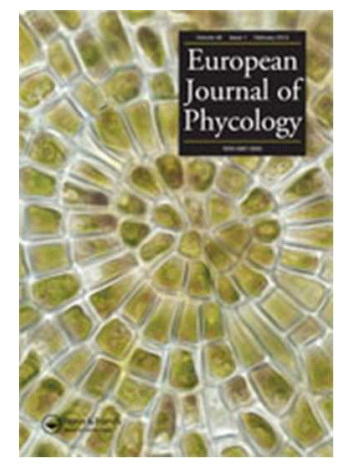

\title{
The genera Melanothamnus Bornet \& Falkenberg and Vertebrata S.F. Gray constitute well-defined clades of the red algal tribe Polysiphonieae (Rhodomelaceae, Ceramiales)
}

\begin{tabular}{|c|c|}
\hline Journal: & European Journal of Phycology \\
\hline Manuscript ID & TEJP-2016-0091.R1 \\
\hline Manuscript Type: & Original Article \\
\hline Date Submitted by the Author: & $n / a$ \\
\hline Complete List of Authors: & $\begin{array}{l}\text { Díaz-Tapia, Pilar; University of A Coruña, Departamento de Bioloxía } \\
\text { Animal, Vexetal e Ecoloxía; University of Melbourne, School of BioSciences; } \\
\text { Bournemouth University, Faculty of Science and Technology } \\
\text { McIvor, Lynne; Queen's University Belfast, School of Biological Sciences } \\
\text { Freshwater, David; University of North Carolina at Wilmington, Center for } \\
\text { Marine Science } \\
\text { Verbruggen, Heroen; University of Melbourne, School of BioSciences } \\
\text { Wynne, Michael; University of Michigan Ann Arbor, Department of Ecology } \\
\text { and Evolutionary Biology and Herbarium } \\
\text { Maggs, Christine; Queen's University Belfast, School of Biological } \\
\text { Sciences; Bournemouth University, Faculty of Science and Technology }\end{array}$ \\
\hline Keywords: & $\begin{array}{l}\text { Biogeography, Evolution, Molecular systematics, morphology, phylogeny, } \\
\text { Polysiphonia, Red algae, Time calibration }\end{array}$ \\
\hline
\end{tabular}


1

1 The genera Melanothamnus Bornet \& Falkenberg and Vertebrata S.F. Gray constitute well-

2 defined clades of the red algal tribe Polysiphonieae (Rhodomelaceae, Ceramiales) 3

4 PILAR DÍAZ-TAPIA ${ }^{1,2,3}$, LYNNE MCIVOR $^{4}$, D. WILSON FRESHWATER ${ }^{5}$, HEROEN

5 VERBRUGGEN ${ }^{3}$, MICHAEL J. WYNNE ${ }^{6}$ AND CHRISTINE A. MAGGS ${ }^{2,4}$

6

$7 \quad$ BioCost Research Group, Universidad de A Coruña, 15071, A Coruña, Spain

$8 \quad{ }^{2}$ Faculty of Science and Technology, Bournemouth University, Talbot Campus, Poole, Dorset

9 BH12 5BB, UK

$10 \quad{ }^{3}$ School of BioSciences, University of Melbourne, Victoria 3010, Australia

$11{ }^{4}$ School of Biological Sciences, Queen's University Belfast, Medical Biology Centre, BT9 7BL,

12 Northern Ireland

$13{ }^{5}$ Center for Marine Science, University of North Carolina at Wilmington, 5600 Marvin Moss Lane,

14 Wilmington, NC 28409, USA

$15{ }^{6}$ Department of Ecology and Evolutionary Biology and Herbarium, University of Michigan Ann

16 Arbor, MI 48109, USA

17

18 Running title: The genera Melanothamnus and Vertebrata (Rhodophyta)

*Correspondence to: Pilar Díaz-Tapia (e-mail: pdiaz@udc.es) 
Polysiphonia is the largest genus of red algae, and several schemes subdividing it into smaller taxa

2

\section{ABSTRACT}

have been proposed since its original description. Most of these proposals were not generally accepted, and currently the tribe Polysiphonieae consists of the large genus Polysiphonia (190 species), the segregate genus Neosiphonia (43 species), and 13 smaller genera ( $<10$ species each). In this paper, phylogenetic relationships of the tribe Polysiphonieae are analysed, with particular emphasis on the genera Carradoriella, Fernandosiphonia, Melanothamnus, Neosiphonia, Polysiphonia sensu stricto, Streblocladia and Vertebrata. We evaluated the consistency of 14 selected morphological characters in the identified clades. Based on molecular phylogenetic $(r b c \mathrm{~L}$ and $18 \mathrm{~S}$ genes) and morphological evidence, two speciose genera are recognized: Vertebrata (including the type species of the genera Ctenosiphonia, Enelittosiphonia, Boergeseniella and Brongniartella) and Melanothamnus (including the type species of the genera Fernandosiphonia and Neosiphonia). Both genera are distinguished from other members of the Polysiphonieae by synapomorphic characters, the emergence of which could have provided evolutionarily selective advantages for these two lineages. In Vertebrata trichoblast cells are multinucleate, possibly associated with the development of extraordinarily long, photoprotective, trichoblasts.

Melanothamnus has 3-celled carpogonial branches and plastids lying exclusively on radial walls of the pericentral cells, which similarly may improve resistance to damage caused by excessive light. Other relevant characters that are constant in each genus are also shared with other clades. The evolutionary origin of the genera Melanothamnus and Vertebrata is estimated as 75.7-95.78 and 90.7-138.66 Ma, respectively. Despite arising in the Cretaceous, before the closure of the Tethys 46 Seaway, Melanothamnus is a predominantly Indo-Pacific genus and its near-absence from the 47 northeastern Atlantic is enigmatic. The nomenclatural implications of this work are that 46 species 48 are here transferred to Melanothamnus, six species are transferred to Vertebrata and 13 names are 49 resurrected for Vertebrata. 
1

2

3

4

$5 \quad 3$

6

$7 \quad 50$

8

9

10

11

12

13

14

15

16

17

18

19

20

21

22

23

24

25

26

27

28

29

30

31

32

33

34

35

36

37

38

39

40

41

42

43

44

45

46

47

48

49

50

51

52

53

54

55

56

57

58

59

60

54

55

56

57

51

52 Key words: biogeography, evolution, molecular systematics, morphology, phylogeny,

53 Polysiphonia, red algae, time calibration 


\section{INTRODUCTION}

The Rhodomelaceae Areschoug is the largest family of red algae, currently including more than

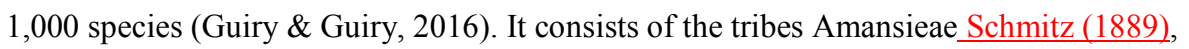
Bostrychieae Falkenberg (1901), Chondrieae Schmitz \& Falkenberg (1897), Herposiphonieae

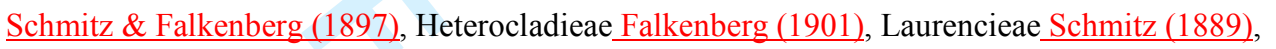
Lophothalieae Schmitz \& Falkenberg (1897), Neotenophyceae Kraft \& I.A.Abbott (2002), Pleurostichidieae_(Hommersand, 1963), Polysiphonieae Schmitz (1889), Polyzonieae Schmitz \& Falkenberg (1897), Pterosiphonieae Falkenberg (1901), Rhodomeleae Schmitz \& Falkenberg (1897), Sonderelleae L.E.Phillips (2001) and Streblocladieae nom. nud. (Hommersand, 1963; Kraft \& Abbott, 2002; Womersley, 2003), of which the most speciose is the Polysiphonieae with over 300 species in 15 currently recognized genera (Guiry \& Guiry, 2016).

Within the Polysiphonieae the genus Polysiphonia Greville (1824), nom. cons., has representatives throughout the world, in the majority of photic marine benthic habitats including brackish ones (e.g. Womersley, 1979; Hollenberg, 1942, 1944, 1968a, 1968b; Maggs \& Hommersand, 1993; Lam et al., 2013). Polysiphonia is poorly circumscribed, and has remained in a state of taxonomic flux since its original description. Numerous schemes for subdividing this large and morphologically diverse genus into smaller and more manageable groups have been proposed (e.g. Segi, 1951; Hollenberg, 1968a, 1968b), based mostly on the number of periaxial cells, either four (subgenus Oligosiphonia) or more than four (subgenus Polysiphonia). These schemes have generally been rejected and several generic names [e.g. Orcasia Kylin (1941), based on Polysiphonia senticulosa Harvey] are currently regarded as synonyms of Polysiphonia.

However, despite having been subsumed within Polysiphonia in most classification schemes, Vertebrata S.F.Gray (1821) is currently recognized as a monospecific genus containing only the type species, V. lanosa (Linnaeus) T.A.Christensen.

The segregate genus Neosiphonia M.-S.Kim \& I.K.Lee (Kim \& Lee, 1999) has been widely accepted and is now the second largest in the Polysiphonieae (Guiry \& Guiry, 2016). Neosiphonia 

5

(type species: N. flavimarina M. S.Kim \& I.K.Lee from Korea) is characterized by the following features: (1) thalli erect with a main axis bearing branches; (2) branches or trichoblasts formed on every segment; (3) rhizoids cut off from pericentral cells; (4) carpogonial branches 3-celled; (5) spermatangial branches formed on a branch of modified trichoblasts; (6) tetrasporangia in-a spiral arrangement (Kim \& Lee, 1999). These features contrast markedly with the key characters of Polysiphonia sensu stricto, exemplified by the type species $P$. stricta(Dillwyn) Greville: prostrate axes with rhizoids in open connection with pericentral cells; carpogonial branches 4-celled; spermatangial branches borne directly on axes; tetrasporangia in straight rows (Kim et al., 2000). In addition to describing the new species $N$. flavimarina, Kim \& Lee (1999) also transferred eleven species of Polysiphonia to Neosiphonia, all based on material from Korea, and there are 43 currently recognized species (Guiry \& Guiry, 2016), not all of which exhibit the six key characters of Neosiphonia listed above.

Kim \& Lee (1999) considered Neosiphonia (also referred to as the "Polysiphonia japonica complex" sensu Yoon (1986)) to be related to Fernandosiphonia Levring, which was erected for F. unilateralis Levring from the Juan Fernández Islands off Chile on the basis of its unilateral development of ultimate branches (Levring, 1941) and which currently consists of three species. They reported that Neosiphonia differed from Fernandosiphonia principally in its branching pattern, the origin of spermatangial branches, and the 3-celled carpogonial branches. Kim \& Lee (1999) did not comment, however, on the possible relationship between Fernandosiphonia and Streblocladia F. Schmitz (in Schmitz \& Falkenberg, 1897). Hommersand (1963) and Norris (1994) compared Fernandosiphonia (trichoblasts formed spirally) with Streblocladia (trichoblasts borne only adaxially). Choi et al. (2001) drew attention to the relationship in their $18 \mathrm{~S}$ tree between $N$. japonica (Harvey) M. S.Kim \& I.K.Lee-and Polysiphonia virgata (C.Agardh) Sprengel, the type species of Carradoriella P.C.Silva (Kylin, 1956, as Carradoria; Silva et al., 1996), and suggested that Neosiphonia might either be subsumed into Carradoriella or be resolved as a sister to it. Recent searches of DNA sequence databases unexpectedly showed a possible relationship between 
6

Neosiphonia species and Melanothamnus somalensis Bornet \& Falkenberg, the type species of the genus Melanothamnus Bornet \& Falkenberg(in Falkenberg, 1901), which was regarded as incertae sedis by Bornet \& Falkenberg in_(Falkenberg ${ }_{2}(1901)$.

Given the taxonomic and nomenclatural complexity within the Polysiphonieae, our aims were to re-evaluate the morphological features of Neosiphonia and Vertebrata in relation to those of Fernandosiphonia, Streblocladia, Carradoriella, Melanothamnus and Polysiphonia sensu stricto within a phylogenetic analysis of the Polysiphonieae using sequences of the plastid-encoded $r b c \mathrm{~L}$ gene and the ribosomal DNA $18 \mathrm{~S}$ gene (SSU). We surveyed within the Polysiphonieae the distribution of a striking characteristic of the "Polysiphonia japonica complex", the position of plastids on radial walls of the periaxial cells and their absence from the outer walls such that nuclei are clearly visible after staining (Maggs \& Hommersand, 1993; McIvor et al., 2001). Likewise, we analysed the multinucleate $v s$. uninucleate character of trichoblast cells, which seems to be taxonomically significant (Maggs \& Hommersand, 1993).

\section{MATERIALS AND METHODS}

Field collections, morphological studies and literature review

Samples of Polysiphonieae (Table S1) were collected from European Atlantic coasts, New Zealand, Australia, Taiwan, Japan, Chile, USA, South Africa and Oman and processed fresh, desiccated in silica gel or preserved in ethanol. Botanical Museum, Göteborg, Sweden (GB) by correspondence with the curator. It consisted in-of four permanent slides, a herbarium sheet and formalinliquid--preserved material. Furthermore, we studied recent collections from Juan Fernández Islands, the type locality. We also studied the type 
7

136 material in US and TCD of several species currently assigned to Neosiphonia (Table S2;

137 herbarium abbreviations as in Thiers, 2016) for which the key morphological characteristics (Table

138 1) could not be clearly ascertained from published literature, in order to determine their correct 139 generic assignment. For this purpose, we exclusively considered the descriptions provided for 140 material from type localities or near them. To ensure the accuracy of our interpretation of the 141 genera, our concept of them is based on material of their type species obtained from their type 142 localities. For Streblocladia, we used material of, and sequences from, the type species $S$. 143 glomerulata (Montagne) Papenfuss from New Zealand. Carradoriella (i.e. Polysiphonia virgata) 144 was obtained from the type locality in South Africa, and the type species of Vertebrata and 145 Melanothamnus came from Ireland and Oman respectively.

146 Fresh material and herbarium samples were prepared as squashes, either unstained or stained 147 with aqueous aniline blue, post-fixed in $1 \% \mathrm{HCl}$, and mounted in $80 \%$ Karo corn syrup (Bestfoods 148 Inc, NJ, USA). Permanent slide mounts were prepared as vouchers and deposited in: BM, MICH, 149 SANT, WNC and MEL.

150 A systematic review was carried out to identify relevant phycological literature from 151 around the world from which to assess for each species of Polysiphonieae the 14 vegetative and 152 reproductive features relevant to Neosiphonia and Vertebrata.

153 Nomenclatural authorities for the species mentioned in the manuscript are provided in 154 155

156 DNA extraction, PCR amplification and sequencing

158 This was carried out in four different laboratories using different protocols as described below. At Queen's University Belfast, DNA was extracted from fresh, silica gel-dried or ethanol160 preserved material using the Qiagen DNeasy Plant Mini Kit (Qiagen GmbH, Hilden, Germany), 161 according to the manufacturer's instructions, or by a CTAB method, modified after Doyle \& Doyle 
162

(1987). For PCR amplification, a PTC-200 DNA Engine (MJ Research Inc.) was used. Except for material of Fernandosiphonia unilateralis, all PCR amplifications were carried out using rbcLFC as the forward primer, and rbcLRD as the reverse primer (Nam et al., 2000; McIvor et al., 2001). All reactions contained $200 \mu \mathrm{M}$ each of dATP, dCTP, dGTP and dTTP, $0.3 \mu \mathrm{M}$ of each primer, $2.5 \mathrm{mM} \mathrm{MgCl}_{2}$, and 1.6 units of Biotaq ${ }^{\mathrm{TM}}$ DNA Taqpolymerase (Bioline, UK). The PCR amplification followed Nam et al. (2000) and McIvor et al. (2001). About 1250 base pairs (bp) of the $r b c \mathrm{~L}$ gene were amplified using rbeLFC and rbeLRPand t-The PCR fragments for sequencing were purified using the High Pure PCR Product Purification Kit (Roche Diagnostics Ltd., Lewes, UK), according to the manufacturer's instructions. The PCR products were directly sequenced commercially by MWG-Biotech, Ebersberg, Germany.

Type material of Fernandosiphonia unilateralis had been preserved in Fformalin by Levring (1941) prior to long-term storage in ethanol (A. Athanasiados, personal communication). At the Leiden herbarium, various protocols for retrieving DNA from formalin-preserved specimens were attempted (Kirby \& Reid, 2001); the most successful was to soak and wash the material repeatedly in clean sterile water, prior to DNA extraction using using a Chelex-100 (Biorad, Hercules, California) protocol (Goff \& Moon, 1993; Zuccarello et al., 1999). Applying a strategy for amplifying degraded "ancient" DNA (Provan et al., 2008), primers were designed from an alignment of Neosiphonia harveyi (Bailey) M.-S.Kim, H.-G.Choi, Guiry \& G.W.Saunders and related species in order to amplify 100-bp fragments. We used the primers F183 (5',

\section{TGCAGGTGAATCTTCTACAGCT 3') and R383 (5' ACGTTACCAATAATTGAAGCTGTT} 3').

At the University of Melbourne, DNA was extracted from silica gel-dried material following Saunders \& McDevit (2012). PCR amplification was carried out for $r b c \mathrm{~L}$ using the primers F7/RrbcStart or F57/rbcLrevNEW (Freshwater \& Rueness, 1994; Saunders \& Moore, 2013) and for $18 \mathrm{~S}$ using the primers F47 (5' AGCCATGCAAGTGCCTGTAT 3') and R1867 (5'CGCAGGTTCACCTACGGAAA 3'). Reactions were performed in a total volume of $25 \mu 1$, 
9 consisting of $5 \mu 15 \times \mathrm{MyTaq}^{\mathrm{TM}}$ reaction buffer, $0.7 \mu 110 \mu \mathrm{M}$ of forward and reverse primers,

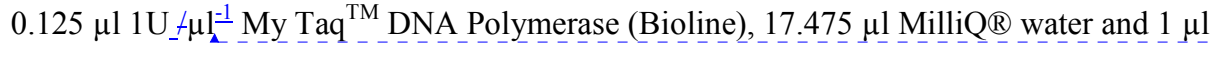
template DNA. The PCR profile consisted of initial denaturation $\left(93^{\circ} \mathrm{C}\right.$ for $\left.3 \mathrm{~min}\right) ; 35$ cycles of denaturation $\left(94^{\circ} \mathrm{C}\right.$ for $\left.30 \mathrm{~s}\right)$, primer annealing $\left(45^{\circ} \mathrm{C}\right.$ for $\left.30 \mathrm{~s}\right)$, and extension $\left(74^{\circ} \mathrm{C}\right.$ for $\left.90 \mathrm{~s}\right)$; and final extension $\left(74^{\circ} \mathrm{C}\right.$ for $\left.5 \mathrm{~min}\right)$. The PCR products were purified and sequenced commercially by Macrogen.

At A Coruña, Melanothamnus from Oman was extracted using the CTAB protocol (Doyle \& Doyle, 1987) and $r b c \mathrm{~L}$ was amplified using the primers F7-R753 and F57-rbcLrevNEW (Freshwater \& Rueness, 1994; Saunders \& Moore, 2013). The PCR products were purified and sequenced commercially by the sequencing service of the University of A Coruña.

DNA extraction, amplification and sequencing at UNCW were as described by Stuercke \& Freshwater (2008).

Sequence alignment and phylogenetic analysis

A total of $65 \mathrm{rbcL}$ and $4818 \mathrm{~S}$ sequences were downloaded from GenBank and 25 new $r b c \mathrm{~L}$ and ten new $18 \mathrm{~S}$ sequences were generated in this study. The sequences and their corresponding GenBank accession numbers are listed in Table S1.

Sequences were aligned using Muscle in Geneious 6.1.8 (Kearse et al., 2012). Identical sequences and those that diverged by less than $1.1 \%$ were removed from the $r b c \mathrm{~L}$ analysis, except for Neosiphonia flavimarina and $N$. harveyi ( $0.4 \%$ divergence), the two selected representatives of the "N. japonica complex" (Kim \& Lee, 1999), which also includes $N$. decumbens, $N$. harlandii and P. akkeshiensis Segi (McIvor et al., 2001; Kim \& Yang, 2006; Savoie \& Saunders, 2015; Bárbara et al., 2013). Identical sequences were also removed from the $18 \mathrm{~S}$ analysis. The sequences included in the final alignment were selected after considering their quality in terms of both length and the presence of ambiguous bases. Phylogenetic trees for $r b c \mathrm{~L}$ and $18 \mathrm{~S}$ were estimated with 
10

214 Maximum Likelihood (ML) using RAxML 8.1.6 (Stamatakis, 2014). GTR-Gamma was selected as

215 the best nucleotide model; branch support was estimated with 100 bootstrap replicates. Three species of Symphyocladia Falkenberg (in Schmitz \& Falkenberg, 1897) were selected as the outgroup in the $r b c$ L phylogeny and one species each of Symphyocladia, Xiphosiphonia Savoie \& Saunders (2016) Pterosiphonia Falkenberg (in Schmitz \& Falkenberg, 1897)and Herposiphonia Nägeli (1846) were selected as outgroups for the $18 \mathrm{~S}$ analysis. This outgroup selection was based on our phylogenomic analyses of the major lineages of the Rhodomelaceae which resolve a clade formed by the Herposiphonieae and Pterosiphonieae as sister to the Polysiphonieae (Díaz-Tapia et al., 2015).

We used MrBayes v.3.2.2 for Bayesian phylogenetic inference (Ronquist et al., 2011). The $r b c \mathrm{~L}$ alignment was analysed using a single (unpartitioned) $\mathrm{GTR}+\Gamma+\mathrm{I}$ as well as completely unlinked GTR $+\Gamma+\mathrm{I}$ for each codon position. We used a single $\mathrm{GTR}+\Gamma+\mathrm{I}$ model for $18 \mathrm{~S}$. All analyses were run for $5 \mathrm{M}$ millions of generations, sampling every 1,000 th generation and using two independent runs each consisting of four incrementally heated Metropolis-coupled (MCMC) chains. Convergence and stationarity of runs were evaluated with Tracer v.1.6.0 (Rambaut et al., 2013), resulting in the use of a burnin of 500k generations for all analyses. Post-burnin trees were summarized with the sumpt command in MrBayes, using the all-compatible-groups consensus type.

Trees were calibrated in geological time using relaxed molecular clock analyses. The calibration was derived from node ages inferred by Yang et al. (2016), which estimated the earliest split in Ceramiales (between Spyridia Harvey (1833) and the remaining Ceramiales) to be $292 \mathrm{Ma}$ old ( $\operatorname{stdev} \approx 24.6 \mathrm{Ma}$ ). After adding the $r b c \mathrm{~L}$ sequences of Ceramiales from the Yang et al. (2016) study to our alignment and setting Spyridia as the outgroup, node ages were inferred with two Bayesian methods. The first analysis used an autocorrelated model of molecular evolutionary rate change (Thorne \& Kishino, 2002) as implemented in PhyloBayes v.3.3f (Lartillot et al., 2009). The MCMC chain was run for 50k cycles, stationarity was assessed with Tracer, and the node ages 
6

11

240 summarized with the readdiv command, discarding the first $25 \mathrm{k}$ cycles as burnin. The second

241 analysis used uncorrelated rates of evolution sampled from a lognormal distribution (Drummond et 242 al., 2006) as implemented in BEAST v.1.8.2. The MCMC chain was run for 10_M-million 243 generations, used a Yule tree prior, and an unpartitioned GTR $+\Gamma+\mathrm{I}$ model of sequence evolution.

244 Stationarity was assessed with Tracer. A maximum clade credibility tree and median node heights 245 were inferred with TreeAnnotator, discarding the first $1 \mathrm{M}-\underline{1}$ million generations as burnin and 246 using a posterior probability limit of zero.

\section{RESULTS}

\section{DNA sequences and alignments}

DNA extraction and PCR amplification of type material of Fernandosiphonia unilateralis that had been initially formalinFormalin/seawater fixed and then stored in ethanol for several decades yielded a 95 bp partial $r b c \mathrm{~L}$ sequence with seven ambiguous nucleotides. The sequence was unique by comparison with other taxa sequenced either at QUB or in Leiden, confirming that there had been no contamination.

25 new $r b c \mathrm{~L}$ sequences and ten $18 \mathrm{~S}$ sequences were obtained from members of the Polysiphoniae (Table S1), including an $r b c \mathrm{~L}$ sequence from Melanothamus somalensis, and four $r b c \mathrm{~L}$ and two $18 \mathrm{~S}$ sequences from new collections of $F$. unilateralis from the type locality. Alignments for the $r b c \mathrm{~L}$ were unambiguous, with no insertions or deletions.

\section{Phylogenetic analyses}

The ML $r b c$ L tree (Fig. 1) has three strongly supported major clades within the Polysiphonieae:

Polysiphonia sensu stricto 1 (including P. stricta, the type of the genus), Polysiphonia sensu stricto 2 (with morphological features corresponding to those defining Polysiphonia sensu stricto: 
12

266 Kim et al., 2000) and a third clade grouping all the other taxa. The third clade comprised a large 267 number of lineages, many with low or intermediate support. The two most speciose lineages, here 268 named Vertebrata and Melanothamnus, however, are both robustly supported (Fig. 1). The 269 Vertebrata clade includes $V$. lanosa, the current name for the type species of Vertebrata, $V$. 270 fastigiata S.F.Gray (1821), as well as the type species of several other genera: Brongniartella Bory 271 (1822), Boergeseniella Kylin (1956), Enelittosiphonia Segi (1949) and Ctenosiphonia Falkenberg 272 (in Schmitz \& Falkenberg, 1897). The Melanothamnus clade includes Fernandosiphonia 273 unilateralis, Neosiphonia flavimarina, and M. somalensis, the type species of their corresponding 274 genera. In addition to these two large clades, six other lineages containing 3-4 species are highly 275 supported (BP/PP > 94/0.95); among these are the Carradoriella clade including Polysiphonia virgata, the type species of Caradoriella, and the Streblocladia clade, which includes the type species S. glomerulata. Our phylogenetic tree also resolved five individual species as sisters to the other clades with low support.

The Melanothamnus clade receives support of 100/1.00 (Fig. 1). In addition to $F$. unilateralis, $N$. flavimarina and $M$. somalensis, this clade includes 27 other species currently assigned to Neosiphonia and Polysiphonia. The 95 bp sequence obtained from the type material of F. unilateralis analysed separately showed that this sequence was positioned unequivocally within the Melanothamnus clade, but sequence ambiguities due to the quality of the DNA made it impossible to determine its precise position.

The phylogenetic relationships among species within the Melanothamnus clade are generally poorly resolved, with a few exceptions. Although the lineage formed by "Polysiphonia" schneideri, "P." amplacapilli, "P.."pentamera and "P." morroides is very weakly positioned as sister to the Melanothamnus clade in the $r b c \mathrm{~L}$ tree, in $18 \mathrm{~S}$ analyses this position is robustly supported (see below).

The RAxML 18S tree (Fig. 2) has a similar topology to the $r b c$ L phylogeny, with three strongly supported major clades: Polysiphonia sensu stricto 1 and 2 and a third clade with all the 
13

292 other taxa. Polysiphonia sensu stricto clades 1 and 2 are placed robustly together (99/1.00). Within

293 the third clade, the Vertebrata clade receives full support, while support is lower for

Morphological observations

An overview of the distribution of selected morphological characters within clades of the Polysiphonieae is shown in Table 1.

Habit: There is considerable variation within and among clades (Table 1), with the exception of 313 Members of the Polysiphonieae are typically smaller than $10 \mathrm{~cm}$. As an exception, M. afaqhusainii 314 can exceed $1 \mathrm{~m}$ in length.

Rhizoids: The connection between the rhizoids and the pericentral cells from which they originate 317 is a uniform character within each clade, so far as it can be observed (Table 1). Rhizoids are in 
318 open connection with pericentral cells in Polysiphonia sensu stricto (Fig. 19), while they are cut

319 off from pericentral cells in the other clades (Figs 20-24). Observations on rhizoids cannot be

320 made in mature specimens of some species, such as Vertebrata lanosa which is an obligate hemi-

321 parasite that lacks rhizoids, and Fernandosiphonia unilateralis, Streblocladia glomerulata and

322 Melanothamnus somalensis, which all have compact basal discs without individual rhizoids.

324 Pericentral cells and cortication: The number of pericentral cells and the presence of cortication 325 are variable in most of the clades (Table 1). All species in the Vertebrata clade have six or more 326 pericentral cells, while members of the Polysiphonia sensu stricto clades have four pericentral 327 cells, with the exception of Bryocladia cuspidata (6-8 pericentrals). Cortication is uniformly 328 absent in the Polysiphonia sensu stricto and "P." schneideri clades. Cortication is variable within 329 the other clades, absent or slight in small species of Fernandosiphonia but very heavy in 330 Melanothamnus, and absent or slight in most species of Vertebrata with the exception of 331 Boergeseniella, in which cortication is elaborate.

333 Plastid arrangement: The arrangement of plastids in the cells is a synapomorphy for the 334 Melanothamnus clade. The species in this clade have the plastids lying exclusively on radial walls 335 of pericentral cells so the outer walls appear transparent (Table 1, Figs 8, 13, 34-39). This 336 particular arrangement of the plastids can be easily observed under the microscope as the cells 337 show a dark flank when observed in detail (Figs 14, 35, 37), as well as a transparent halo when the 338 pericentral cells are observed in a suitable position (Fig. 38). All the other taxa of the 339 Polysiphonieae have plastids against all the cell walls including the outer wall (Table 1, Figs 25340 33). The revision of the type materials listed in Table S2, currently assigned to Neosiphonia, 341 allowed us to verify the plastid character in the species Polysiphonia concinna, P. eastwoodiae, $P$. 342 gorgoniae, P. harlandii and P. johnstonii. Conversely, the species Lophosiphonia mexicana, $P$. 
15

343 beaudettei, P. confusa, P. poko, P. profunda and P. rubrorhiza have the plastids scattered within 344 the cells, including against the outer wall cells.

Branch/trichoblast arrangement: Whether trichoblasts and/or branches are formed on every segment or are separated by naked segments is variable in three clades, Melanothamnus, Carradoriella and Vertebrata. Most species of the Melanothamnus clade have branches or trichoblasts on every segment, which is a key feature of Neosiphonia. However, there are exceptions in this clade such as Neosiphonia collabens, Polysiphonia nuda and P. pseudovillum from Panama, in which there are interspersed naked segments. Conversely, the formation of trichoblasts/branches with naked segments between them is a uniform character in the Streblocladia, "Polysiphonia" schneideri and Polysiphonia sensu stricto clades (Table 1). Within all clades except Melanothamnus, branches may form in a position axillary to trichoblasts, but although constant at the species level, this character is variable within clades. In the Melanothamnus clade this character is absent, and branches are never axillary.

\section{Trichoblast nuclei: The proximal cells of trichoblasts are multinucleate in the Vertebrata clade} (Table 1, Figs 41-43), with up to 8 or more nuclei in the basal cell and decreasing in number towards the apices, which can be uninucleate. The nuclei are uniformly distributed inside the cells, each appearing to have a domain within the cell. Conversely, all the cells of trichoblasts are uninucleate in other clades of the Polysiphonieae (Figs 40, 44-46). The only known exception is Leptosiphonia schousboei, which sometimes has two nuclei in the trichoblast cells.

\section{Branching pattern: Despite the great significance previously placed on dorsiventral vs. radial} branching in the Rhodomelaceae, this character varies within all our clades. A primary dorsiventral branching pattern characterizes some species of the clades Melanothamnus (F. unilateralis and $N$. collabens; Figs 10,11), Streblocladia (S. glomerulata) and Vertebrata (Ctenosiphonia hypnoides) 
369 (Table 1). However, this characteristic is not significant in delineating these three genera, as our 370 phylogenetic tree reveals that each of these four species is closely related to others that have 371 spirally or pseudodichotomously arranged branches. For example, the branching pattern of 372 members of the Streblocladia clade varies from dorsiventral in S. glomerulata, the type species, to

Spermatangial branches: Whether spermatangial branches replace trichoblasts completely or replace only one branch of a dichotomously branched trichoblast is a constant character in all clades (Table 1). In the two Polysiphonia sensu stricto and Streblocladia clades, spermatangial branches almost uniformly replace trichoblasts (Fig. 47). In the other clades, they are formed on the first dichotomy of modified trichoblasts (Figs 15, 49-52), with the exception of Vertebrata (Fig. 48) as $V$. lanosa has no trichoblasts in male thalli - they can only be observed occasionally in females. The presence or absence of apical sterile cells on spermatangial branches is variable within clades, except for Carradoriella in which they are present (Figs 47-52, Table 1).

Carpogonial branches: The Melanothamnus clade is characterized by having 3-celled carpogonial branches (Table 1). In our study, we observed this character in N. harveyi, N. collabens, P. blandi and P. forfex (Figs 57, 58). By contrast, the other Polysiphonieae uniformly have 4-celled carpogonial branches like the majority of the Rhodomelaceae (Table 1, Figs 53-56).

\section{Cystocarps: The outline morphology of cystocarps varies from globose to ovoid in all the clades} analysed here (Table 1, Figs 60-64). Urceolate cystocarps are exclusive to the Polysiphonia sensu stricto clades (Table 1, Fig. 59). Cells around the ostiole are conspicuously larger than (more than twice the size of) the cells of the pericarp immediately below in most species of the 
17

395 Melanothamnus clade (Fig 70). However, Neosiphonia harveyi is an exception, and the cells of 396 the ostiole in this species are only slightly larger than the other cells of the pericarp. This character 397 is also seen in Streblocladia glomerulata (Fig. 68). Conversely, the cells of the ostiole in the other 398 four clades are uniformily similar to the cells below (Figs 65-67, 69).

400 Tetrasporangia: The formation of tetrasporangia in straight or spiral rows is variable in all clades 401 (Table 1, Figs 71-76). It must be noted that very long straight series of tetrasporangia are typically 402 observed only in members of the Polysiphonia sensu stricto clade (Fig. 71). However, straight 403 series can also form in other clades, for example in Neosiphonia collabens and Polysiphonia nuda 404 within the Melanothamnus clade whereas tetrasporangia in Fernandosiphonia unilateralis form 405 short and markedly spiral series (Fig. 18). The third tetrasporangial cover cell is exclusive to the 406 Polysiphonia sensu stricto clade, but this character has not been examined in all the species.

\section{DISCUSSION}

\section{Phylogenetic analysis}

Amongst the Polysiphonieae studied here, the early-branching clade/clades Polysiphonia sensu stricto 1 and 2 were resolved as separate lineages in $r b c \mathrm{~L}$ analyses (Fig. 1) but together formed a robust clade in $18 \mathrm{~S}$ analyses (Fig. 2). The marked discordance between $r b c \mathrm{~L}$ and $18 \mathrm{~S}$ trees regarding the monophyly/paraphyly of the Polysiphonia sensu stricto lineages requires additional research for a more accurate assessment of relationships and character evolution. Because the Polysiphonia sensu stricto lineages occur near the base of the tree, it is possible that the outgroups (which are relatively distant taxa compared to the ingroup) could have attached to the ingroup in the wrong position in one of the analyses (Shavit et al., 2007). Future work should focus on 
420 including a wider range of taxa from across the Rhodomelaceae as well as using larger, multi-gene 421 datasets to infer the correct branching order of the two Polysiphonia sensu stricto lineages.

The Vertebrata and Melanothamnus clades were resolved as large, speciose clades with strong support using $r b c \mathrm{~L}$. The $18 \mathrm{~S}$ phylogeny also resolves the Vertebrata clade with robust support, while Melanothamnus is moderately well supported. Both clades are clearly distinguished from Polysiphonia sensu stricto by the rhizoid anatomy (cut off from pericentral cells). Both clades are identified by distinct morphological synapomorphies. The Vertebrata clade is characterized by the multinucleate cells of trichoblasts; the other key feature of Vertebrata, that all species have six or more pericentral cells, is shared with members of some other clades. The Melanothamnus clade is unequivocally distinguished from other Polysiphonieae by two synapomorphic characteristics: the plastid arrangement and the 3-celled carpogonial branches. Furthermore, branch origin is independent from trichoblasts in all the species of this clade, and the majority of species have enlarged ostiolar cells.

In addition to the above-mentioned clades, the $r b c$ L phylogeny resolved six small (3-4 species) but highly supported clades, as well as indicating five species that are uncertainly positioned. The generic assignment of these lineages requires further taxon and gene sampling in order to better understand their phylogenetic relationships and establish a natural classification_-it would be premature to speculate on the outcomes of these investigations at present. One of the major shortcomings in Polysiphonieae sequence databases is the uneven geographical sampling, as the majority of sequenced taxa come from Atlantic Europe and northwestern America. The generation of molecular data from additional regions could contribute to acquiring a more realistic perspective of the magnitude of unplaced lineages and to delineating their corresponding genera. Also, the resolution of the commonly employed molecular markers in the Polysiphonieae is not sufficient to resolve the phylogenetic relationships among numerous lineages, which could be improved using larger gene datasets (Díaz-Tapia et al., 2015). 
19

\section{Taxonomic position of Vertebrata}

447 Vertebrata lanosa is placed in a strongly supported clade that also includes Brongniartella 448 byssoides, Boergeseniella fruticulosa, Ctenosiphonia hypnoides and Enelittosiphonia stimpsonii, 449 the type species of their corresponding genera, and Lophosiphonia reptabunda (which is not the 450 type species). All members of this clade have a synapomorphic characteristic that was previously 451 overlooked in relation to systematics (but see Maggs \& Hommersand, 1993): multinucleate 452 trichoblast cells._We conclude from molecular and morphological evidence that members of this 453 clade represent a single genus. Vertebrata is the oldest name among those available for this clade, 454 as noted before (Choi et al., 2001), and the new combinations proposed in Table 2 are required. 455 Furthermore, the Vertebrata binomials previously established by Kuntze (1891) should be 456 reinstated for the other 13 species included in this clade (Table 3). 457 Interestingly, Brongniartella is not monophyletic despite its distinctive persistent and 458 pigmented trichoblasts that led to its classification in the tribes Lophothalieae (Falkenberg, 1901;

Womersley, 2003) or Brongniartelleae Parsons (Parsons, 1975; Maggs \& Hommersand, 1993). Although trichoblasts are typically considered unpigmented in the Polysiphonieae, they are commonly pigmented when young before they enlarge and become colourless (Delivopoulos, 2002). The two currently recognized species of Brongniartella, B. byssoides and B. australis, were separated within the Vertebrata clade, respectively placed with V. lanosa and Polysiphonia nigra.

Ctenosiphonia is a monotypic genus segregated from Polysiphonia due to its very peculiar morphological characteristics, including a dorsiventral thallus and two tetrasporangia per segment (Falkenberg, 1901; Díaz-Tapia \& Bárbara, 2013). This genus, together with Lophosiphonia Falkenberg (1987), is currently positioned within the "Lophosiphonia group" (Falkenberg, 1901). Boergeseniella and Enelittosiphonia were distinguished from other Polysiphonieae by their particular branching patterns (Kylin, 1956; Segi, 1949), but our molecular evidence (Fig. 1) does not support their recognition as independent genera. 
20

The diversity of currently recognized genera included in this clade reflects the high variability among Vertebrata species in trichoblast characteristics (pigmented/unpigmented; persistent/deciduous; spirally/dorsiventrally arranged) and branching patterns (spiral/dorsiventral; presence or absence of alternating branches of determinate and indeterminate growth), which classical authors considered important at levels of genus and tribe (Falkenberg, 1901; Kylin, 1956; Hommersand, 1963).

The main morphological character delineating the Vertebrata group is that trichoblast cells are multinucleate. In the Polysiphonieae and some other Ceramiales, the apical cell is uninucleate, whereas the cells cut off from it undergo nuclear divisions during elongation, becoming multinucleate, with the number of nuclei being proportional to the volume of the cell (Goff \& Coleman, 1986; McIvor et al., 2002). The trichoblasts of the Rhodomelaceae are usually uninucleate, whereas the polysiphonous parts of the thalli are multinucleate (Coomans \& Hommersand, 1990; Garbary \& Clarke, 2001; Delivopoulos, 2002). A plausible advantage of having multinucleate trichoblasts in Vertebrata is that their cells can reach larger sizes. In fact, trichoblasts in this genus are sometimes extremely well developed, exceeding $10 \mathrm{~mm}$ in length in species such as Vertebrata (Lophosiphonia) reptabunda and V. (Ctenosiphonia) hypnoides. In the red algae, cell streaming is slow compared with other algae (Pueschel, 1990), and multinuclearity of large cells may facilitate the regulation of cellular activities. Several potential functions have been attributed to the vegetative hairs of the red algae or trichoblasts of the Rhodomelaceae including dessication resistance, nutrient uptake, metabolite secretion, shading, trapping of spermatia, mucilage stabilization and monitoring of phosphorus status (Delivopoulos, 2002, and references therein). Physically, trichoblasts can form a dense network around the apices that could potentially restrict access to the cells by small grazers, such as amphipods and copepods.

\section{Taxonomic position of Neosiphonia, Fernandosiphonia and Melanothamnus}


497 The presence of the type species of the genus Melanothamnus (M. somalensis) in a strongly

498 supported clade with the type species of the genus Neosiphonia (N. flavimarina) and 499 Fernandosiphonia (F. unilateralis) indicates that Neosiphonia, Fernandosiphonia and 500 Melanothamnus are not distinct monophyletic genera. Neosiphonia is a later heterotypic synonym 501 of Fernandosiphonia. However, the name Melanothamnus is older than both Fernandosiphonia 502 and Neosiphonia, and the new combinations proposed in Tables 4 and 5 are required. These new 503 combinations include 31 species that were previously assigned to Neosiphonia; two species known 504 to be closely related to Neosiphonia but that had been retained in Polysiphonia because their 505 morphology conflicted with Kim \& Lee (1999); six species for which molecular data are presented 506 here for the first time; and three species that are transferred to Melanothamnus on the basis of their 507 morphology.

508 On the other hand, ten species that are currently placed in Neosiphonia should be replaced in 509 Polysiphonia for formal purposes pending clarification of their phylogenetic affinities and generic 510 assingment. Polysiphonia beaudettei, P. confusa, P. echinata, P. elongella, P. poko, P. rubrorhiza 511 and P. profunda were assigned to Neosiphonia based on morphological characteristics (Kim \& 512 Lee, 1999; Abbott et al., 2002; Kim \& Abbott, 2006; Mamoozadeh \& Freshwater, 2011; Norris, 513 2014). However, they lack the plastid character, and furthermore molecular data for P. echinata 514 and P. elongella show that they do not belong to the Melanothamnus clade (Fig. 1). Likewise, 515 Polysiphonia sertularioides was transferred to Neosiphonia based on the morphology of Korean 516 material attributed to this species (Nam \& Kang, 2012). However, its type locality is in the 517 Mediterranean, and Atlantic sequences for this species are not in the Fernandosiphonia clade (Fig. 518 1; Mamoozadeh \& Freshwater, 2012). Polysiphonia paniculata was transferred to Neosiphonia 519 (Norris, 2014), but again it is not in the Melanothamnus clade (Figs 1, 2). Finally, our study of the 520 type material of Lophosiphonia mexicana, also transferred to Neosiphonia (Norris, 2014; Table 521 S2), leads us to conclude indicates that this species is probably not a member of the 522 Polysiphonieae. As noted by Norris (2014), further studies are needed to clarify the generic 


\section{2}

523 placement of this unusual species, and meanwhile we propose to leave it in Lophosiphonia until

524 more information is available.

Specimens of Melanothamnus collected in Oman and housed in MICH were initially assigned to M. somalensis (Wynne \& Banaimoon, 1990), before the description of M. afaqhusainii M.Shameelfrom Pakistan (1999). Revision of the Omani materials leads us to conclude that both M. somalensis and M. afaqhusainii are represented in Oman, and their morphology agrees with the criteria proposed by Shameel $(1999,2000)$ for distinguishing them. Their $r b c \mathrm{~L}$ sequences diverged by $1.4 \%(18 \mathrm{bp})$.

The Melanothamnus clade is morphologically distinguished from other members of the tribe 532 Polysiphonieae by an unequivocal synapomorphic character: plastids lie exclusively on the radial walls of the pericentral cells and are absent from outer walls. The plastid character was previously noted by Hollenberg $(1961,1968 a)$, who described "hyaline cell walls" for several species (e.g. $P$. pseudovillum, P. bajacali), and by Maggs \& Hommersand (1993). However, its significance at higher taxonomic levels has not previously been highlighted. We observed this character in a total of 35 species, and we conclude that it is uniform in the Melanothamnus clade. Conversely, other Polysiphonieae and most of the Rhodomelaceae have plastids distributed within the cytoplasm, some lying against outer cell walls. In the family, the only other exception is some species of Herposiphonia in which the plastids form transverse bands (Hollenberg, 1968c; Womersley, 2003; Díaz-Tapia \& Bárbara, 2013).

Carpogonial branches are typically 4-celled throughout the family Rhodomelaceae. 3-celled carpogonial branches were described for the first time in Polysiphonia platycarpa (Iyengar \& Balakrishnan, 1950), and later this was one of the features proposed to delineate the genus Neosiphonia (Kim \& Lee, 1999). 3-celled carpogonial branches have been reported in 17 species (four of them in the "japonica-complex"), all of which are placed here in Melanothamnus. Alternative interpretations of the carpogonial branch configuration were found in the literature for F. unilateralis, as Leving (1941) described and illustrated a 4-celled structure, while Morrill (1976, 
549 plate 37, figs E and H) illustrated 3-celled carpogonial branches in the same species, also from the 550 type locality. This character can be easily misinterpreted if the carpogonial branches are not 551 observed at the right developmental stage. In our study of the type material, a single procarp was 552 observed in a permanent slide (Fig. 16), most probably the same one illustrated by Levring. It is 553 unclear how this procarp should be interpreted because it is too mature, and so it is difficult to 554 determine with certainty which cell corresponds to the sterile basal cell and which to the basal cell 555 of the carpogonial branch. From the evidence of the presence of both the plastid character and 3556 celled carpogonial branches, Kintarosiphonia fibrillosa Uwai \& Masuda (1999), based on 557 Pterosiphonia fibrillosa, and Polysiphonia platycarpa are also here transferred to Melanothamnus 558 (Table 1).

559 The other morphological characters proposed by Kim \& Lee (1999) to delineate the genus 560 Neosiphonia vary among closely related species, except for the rhizoid anatomy. Rhizoids are cut 561 off from the pericentral cells in all Polysiphonieae except for Polysiphonia sensu stricto in which 562 they are in open connection with the pericentral cells. After the establishment of Neosiphonia, 563 numerous species were transferred to the new genus based on morphology, but commonly 564 overlooking the number of cells in carpogonial branches. Excluding this trait, several species have 565 all five characteristics proposed by Kim \& Lee (1999) to delineate Neosiphonia but nevertheless 566 are not in the Melanothamnus clade (e.g. P. brodiei, P. echinata, P. elongella), while several 567 species are clearly in the clade (e.g. M. collabens, M. nuda, M. pseudovillum) but lack this 568 combination of traits.

569 The key morphological feature of Melanothamnus is the restriction of plastids to the radial 570 walls of the pericentral cells and their absence from the outer walls. Algae demonstrate a notable 571 decline in photosynthesis at higher light levels possibly due to damage to the photosynthetic 572 apparatus caused by excessive light delivery to photosystem II (Lüning, 1990; Hurd et al., 2014). 573 Many green and brown algal plastids have phototropic reactions to blue and UV light in order to 574 protect them from irradiation damage (Lüning, 1990). Plastid movement, however, has never been 
24

demonstrated for the vast majority of red algae (Pueschel, 1990), and it appears that red algae have evolved other types of protection against UV damage. Red algae including Polysiphonia species have high concentrations of various mycosporine-like amino acids that respond rapidly to environmental change and act as defences against the photooxidative effects of sunlight (Karsten et al., 1998; Navarro et al., 2014). The movement of the plastids onto the radial walls of the periaxial cells, in combination with MAAs, may have given the Melanothamnus ancestor a selective advantage over other Polysiphonieae, allowing it to exploit new ecological niches. The prevalence of Melanothamnus species in habitats with exposure to high light levels, such as in Hawaii or turfs on coral reefs (Price \& Scott, 1992;-; Kim \& Abbott, 2006), supports this speculation.

\section{Biogeography of Vertebrata and Melanothamnus}

The genus Vertebrata is distributed worldwide and representatives have been described from all regions where there has been a detailed study of the tribe Polysiphonieae. The majority of our sequences are from Europe, but our systematic review and unpublished data suggest that this genus is widespread. BEAST and PhyloBayes calibrations indicate radiation of the major lineages of the Vertebrata clade over a 20 MA period starting about 140 or $90 \mathrm{Ma}$ (estimates from different methods; see Figs S1, S2). Further conclusions as to its origins and centres of diversity would be premature, pending more comprehensive sampling.

In contrast, Melanothamnus is predominantly Indo-Pacific (Fig. 77). Although few molecular data are available from Indian coasts, some species occur in South Africa (M. incompta), Oman (M. somalensis and M. afaqhusainii), India (M. platycarpa) and Thailand (M. thailandica). Among the regions for which there is a comprehensive study of the Polysiphonieae, the diversity of Melanothamnus is particularly high in Korea, Japan and Hawaii (14, 11 and 14 species, respectively). This genus is also well represented on North American Atlantic coasts (4-5 species), but it is almost completely absent from Atlantic and Mediterranean Europe, where only 
601 two species have been reported, which are both most probably examples of old human-mediated 602 introductions. Melanothamnus harveyi is native to southeastern Asia and has been introduced by 603 multiple events onto northern Atlantic coasts (McIvor et al., 2001; Savoie \& Saunders, 2016). 604 Similarly, M. collabens is likely to be an old introduction into the Atlantic, where it extends from 605 the Bay of Biscay to Cape Verde, including the western Mediterranean (Díaz-Tapia \& Bárbara, 606 2013). The finding of M. collabens in California (as P. johnstonii, see Table 4) supports this 607 hypothesis, but although Polysiphonia johnstonii was first collected from the Gulf of California in 1921 (Setchell \& Gardner, 1924), California was probably not the original source of the introduction. Polysiphonia johnstonii was first collected from the Gulf of California in 1921 (Setchell \& Gardner, 1924). However an-An investigation of Polysiphonia species from the 611 Northern Gulf of California (Hollenberg \& Norris, 1977) suggested that since its initial collection 612 and description, P. johnstonii has extended its range along the Pacific coast of North America, 613 fulfilling one of the criteria for an invasive species (Chapman \& Carlton, 1991; Ribera \& 614 Boudouresque, 1995). How far this species has spread along the Pacific coast of America and 615 along North Atlantic coastlines remains to be determined, and further sampling is needed to 616 establish its origin.

617 The absence of naturally occurring Melanothamnus species in the Mediterranean and 618 northeastern Atlantic might suggest that Melanothamnus is of recent origin, having evolved in the 619 Pacific Ocean after the closure of the Tethys Seaway, between 60 and 20 million years ago, 620 particularly as the sister " $P$." schneideri clade is also primarily Pacific in distribution. In our $r b c \mathrm{~L}$ 621 phylogeny (Fig. 1), the "P." schneideri clade includes two Korean species and two species 622 distributed in the Pacific and North America with one of them introduced in Europe (Díaz-Tapia et 623 al., 2013). Furthermore, our surveys in Australia revealed five other Indo-Pacific species 624 belonging to this clade (unpublished data). However, BEAST and PhyloBayes calibrations indicate 625 radiation of the major lineages of the Melanothamnus clade over a 12 Ma period starting about 95 626 or $75 \mathrm{Ma}$ (the two methods providing different estimates), with divergence from the " $P$. ." 
627 schneideri clade 140 or $95 \mathrm{Ma}$ (Figs S1, S2). The distribution resembles a Tethyan one that 628 originated during the Cretaceous 125-75 Ma (Lüning, 1990; Hommersand, 2007) when the Tethys 629 Ocean formed a tropical girdle around the earth. Unlike typical Tethyan distributions, in addition 630 to its wide occurrence throughout the tropics, Melanothamnus occupies more temperate regions in 631 the North Pacific (e.g. Japan, Korea) and the South Pacific/Oceania (e.g. South Australia, New 632 Zealand). The question of whether Melanothamnus failed to colonize the northeastern Atlantic as it 633 opened up during the Cretaceous, or whether northeastern Atlantic lineages evolved but became 634 extinct, perhaps during Pleistocene glaciations, cannot be answered at present.

\section{ACKNOWLEDGEMENTS}

639 We are pleased to recognize here that Dr Max H. Hommersand (UNC Chapel Hill) independently 640 discovered the key morphological character of the position of plastids in the Melanothamnus clade.

641 We thank Joana Costa for providing us samples of Polysiphonia spp. from South Africa, and

642 Erasmo Macaya for supplying material from his recent collections of Fernandosiphonia

643 unilateralis from the type locality. Prof. Gary Saunders is thanked warmly for generously sharing 644 sequences for Melanothamnus afaqhusainii from Oman. We acknowledge the curators of the 645 herbaria TFC, US and TCD; Dr Joe Zuccarello provided host support for Lynne McIvor during her 646 Marie Curie fellowship at Leiden Herbarium. PDT acknowledges support by the postdoctoral 647 programmes Axudas de apoio á etapa inicial de formación posdoutoral do Plan I2C (Xunta de 648 Galicia). Funding for the aspects of the work carried out in the Melbourne lab was provided by the 649 Australian Biological Resources Study (RFL213-08) and the Australian Research Council 650 (FT110100585). 
27

\section{3 \\ REFERENCES}

654

Abbott, I. A. (1999). Marine Red Algae of the Hawaiian Islands. Bishop Museum Press, Honolulu.

Abbott, I.A. \& Hollenberg, G.J. (1976). Marine Algae of California. Stanford University Press, Stanford, California.

Abbott, I. A., Fisher, J. \& McDermid, K. J. (2002). New reported and revised marine algae from the vicinity of Nha Trang, Vietnam. In Taxonomy of Economic Seaweeds with Reference to some Pacific Species (Abbott, I. A. \& McDermid, K. J., editors), 291-321. California Sea Grant College, La Jolla.

Adams, N.M. (1991). The New Zealand species of Polysiphonia Greville (Rhodophyta). New Zealand Journal of Botany, 29: 411-427.

Adams, N.M. (1994). Seaweeds of New Zealand. An Illustrated Guide. Canterbury University Press, Christchurch.

Agardh, C. A. (1824). Systema algarum. Berlinginiana, Lundae.

Agardh, C.A. (1828). Species algarum rite cognitae, cum synonymis, differentiis specificis et descriptionibus succinctis. Voluminis secundi. Sectio prior. Sumptibus Ernesti, Greifswald.

Agardh, J.G. (1842). Algae maris Mediterranei et Adriatici, observationes in diagnosin specierum et dispositionem generum. Apud-Fortin, Masson et Cie, Paris.

Agardh, J. G. (1863). Species Genera et Ordines Algarum, seu descriptiones succinctae specierum, generum et ordinum, quibus algarum regnum constituitur. Volumen secundum: algas florideas complectens. C.W.K. Gleerup, Lundae.

Bailey, J.W. (1848). Continuation of the list of localities of algae in the United. American Journal of Science and Arts, series 2, 6: 37-42.

Bárbara, I., Cremades, J., Calvo, S., López-Rodríguez, M. C. \& Dosil, J. (2005). Checklist of the benthic marine and brackish Galician algae (NW Spain). Anales del Jardín Botánico de Madrid, 62: 69-100. 
679 Bárbara, L, Choi, H.-G., Secilla, A., Díaz-Tapia, P. Gorostiaga, J.M., Seo, T.-K., Jung, M.Y. \&

680 Berecibar, E. (2013). Lampisiphonia iberica gen. et sp. nov. (Ceramiales, Rhodophyta) based

Børgesen, F. (1918). The marine algae of the Danish West Indies. Part 3. Rhodophyceae (4). Dansk Botanisk Arkiv, 3: 241-304.

Børgesen, F. (1934). Some Indian Rhodophyceae especially from the shores of the Presidency of Bombay-IV. Bulletin of Miscellaneous Information, Royal Botanic Gardens, Kew, 1934: 1-30.

Bornet, É. (1892). Les algues de P. K. A. Schousboe, récoltées au Maroc \& dans la Méditerranée de 1815 a 1829, et déterminées par M. Édouard Bornet. Mémoires de la Société Nationale des Sciences naturelles et Mathématiques de Cherbourg, 28: 165-376.

Bory de Saint-Vincent, J.B.G.M. (1822). Brongniartelle. Brongniartella. Bot. crypt. (Céramiaires.). In Dictionnaire Classique d'Histoire Naturelle (Audouin, I. et al., editors), 516-517. Rey et Gravier; Baudoin frères, Paris.

Bustamante, D.E., Won, B.Y., Ramirez, M.E. \& Cho, T.O. (2012). Neosiphonia peruviensis sp. nov. (Rhodomelacea, Rhodophyta) from the Pacific coast of South America. Botanica Marina, 55: 359-366.

Bustamante, D. E., Won, B. Y. \& Cho, T. O. (2013a). Neosiphonia ramirezii sp. nov. (Rhodomelaceae, Rhodophyta) from Peru. Algae, 28: 73-82.

Bustamante, D. E., Won, B. Y. \& Cho, T. O. (2013b). Neosiphonia baliana sp. nov. and N. silvae sp. nov. (Rhodomelaceae, Rhodophyta) from Bali, Indonesia. Botanica Marina, 56: 515524.

Chapman, J.W. \& Carlton, J.T. (1991). A test of criteria for introduced species: the global invasion by the isopod Synidotea laevidorsalis (Miers, 1881). Journal of Crustacean Biology, 11: $386-400$. 
29

703 Choi, H. G., Kim, M. S., Guiry, M. D. \& Saunders, G. W. (2001). Phylogenetic relationships of Polysiphonia (Rhodomelaceae, Rhodophyta) and its relatives based on anatomical and nuclear small-subunit rDNA sequence data. Canadian Journal of Botany, 79: 1465-1476.

Coomans, R. J. \& Hommersand, M. H. (1990). Vegetative growth and organization. In Biology of the red algae (Cole, K.M. \& Sheath, R.G., editors), 275-304. Cambridge University Press, Cambridge.

Delivopoulos, S. (2002). Ultrastructure of trichoblasts in the red alga Osmundea spectabilis var. spectabilis (Rhodomelaceae, Ceramiales). European Journal of Phycology, 37: 329-338.

Dawes, C.J. \& Mathieson, A.C. (2008). The Seaweeds of Florida. University Press of Florida, Gainesville, Florida.

713 Dawson, E. Y. (1944). The marine algae of the gulf of California. The University of Southern $714 \quad$ California Publications, 3: 189-359.

715 Díaz-Tapia, P. \& Bárbara, I. (2013). Seaweeds from sand-covered rocks of the Atlantic Iberian 716 Peninsula. Part 1. The Rhodomelaceae (Ceramiales, Rhodophyta). Cryptogamie, Algologie, $717 \quad 34: 325-422$.

718 Díaz-Tapia, P., Kim, M.S., Secilla, A., Bárbara, I. \& Cremades, J. (2013a). Taxonomic reassessment of Polysiphonia foetidissima (Rhodomelaceae, Rhodophyta) and similar species, including P. schneideri, a newly introduced species in Europe. European Journal of Phycology, 48: 345-362.

Díaz-Tapia, P., Bárbara, I., Berecibar, E. (2013b). Vegetative and reproductive morphology of Polysiphonia tripinnata (Rhodmelaceae, Rhodophyta): a new record from the European Atlantic coast. Botanica Marina, 56: 151-160.

Díaz-Tapia, P., Maggs, C.A., West, J.A. \& Verbruggen, H. 2015. Tackling rapid radiations with chloroplast phylogenomics in the Rhodomelaceae. European Journal of Phycology, 50: 5455. 
30

728 Doyle, J. J. \& Doyle, J. L. (1987). A rapid DNA isolation procedure for small quantities of fresh leaf tissue. Phytochemical Bulletin, 1: 11-5.

Drummond, A.J., Ho, S.Y.W., Phillips, M.J. \& Rambaut, A. (2006). Relaxed phylogenetics and dating with confidence. PLoS Biology, 4: e88.

Falkenberg, P. (1901). Die Rhodomelaceen des Golfes von Neapel und der angrenzenden MeeresAbschnitte. Fauna und Flora des Golfes von Neapel, Monographie 26. Berlin.

Freshwater, D. W. \& Rueness, J. (1994). Phylogenetic relationships of some European Gelidium (Gelidiales, Rhodophyta) species, based on $r b c \mathrm{~L}$ nucleotide sequence analysis. Phycologia, 33: $187-194$.

Garbary, D.J. \& Clarke, B. (2001). Apoptosis in trichoblast development in Polysiphonia harveyi (Rhododpyta). Phycologia, 40: 324-329.

Goff, L. J. \& Coleman, A. W. (1986). A novel pattern of apical cell polyploidy, sequential polyploidy reduction and intercellular nuclear transfer in the red alga Polysiphonia. American Journal of Botany, 73: 1109-1130.

Goff, L. J. \& Moon, D. A. (1993). PCR amplification of nuclear and plastid genes from algal herbarium specimens and algal spores. Journal of Phycology, 29: 381-384.

Goodenough, S. \& Woodward, T.J. (1797). Observations on the British Fuci, with particular descriptions of each species. Transactions of the Linnean Society of London, 3: 84-235.

Gray, S. F. (1821). A Natural Arrangement of British Plants.... Baldwin, Cradock \& Joy, Paternoster-Row, London.

Greville, R.K. (1824). Flora Edinensis... William Blackwood, Edinburgh, \& T. Cadell, London.

Grunow, A. (1874). Algen der Fidschi-, Tonga- und Samoa-Inseln, gesammelt von Dr. E. Graeffe. Journal des Museum Godeffroy, 3: 23-50.

Guimarâes, S. M. P. D. B., Fujii, M. T., Pupo, D. \& Yokoya, N. S. (2004). Reavaliaçao das características morfológicas e suas implicaçoes taxonômicas no gênero Polysiphonia sensu 
31

lato (Ceramiales, Rhodophyta) do litoral dos estados de Sao Paulo e Espírito Santo, Brasil. Revista Brasileira de Botânica, 27: 163-183.

Guiry, M.D. \& Guiry, G.M. (2016). AlgaeBase. World-wide electronic publication, National

University of Ireland, Galway. http://www.algaebase.org; searched on 07 February 2016. Hariot, P. (1891). Liste des algues marines rapportés de Yokoska (Japon) par M. le Dr Savatier. Mémoires de la Société nationale des sciences naturelles de Cherbourg, 27: 211-230. Harvey, W.H. (1847). Nereis Australis, or Algae of The Southern Ocean ... [Part 1]. Reeve Brothers, London.

Harvey, W.H. (1853). Nereis boreali-americana; or, contributions towards a history of the marine algae of the Atlantic and Pacific coasts of North America. Part II. Rhodospermeae. Smithsonian Contributions to Knowledge, 5: [i-ii], [1]-258, pls XIII-XXXVI.

Harvey, W.H. (1855). Algae. In: The botany of the Antarctic voyage of H.M. discovery ships Erebus and Terror, in the years 1839-1843, under the command of Captain Sir James Clark Ross... II. Flora Novae-Zelandiae. Part II. Flowerless plants (Hooker, J.D., editor), pp. 211-266. Reeve, London.

Harvey, W.H. (1857 '1856'). Algae. In: Account of the Botanical specimens. (Gray, A., editor) Narrative of the expedition of an American squadron to the China Seas and Japan, performed in the years 1852, 1853 and 1854, under the command of Commodore M.C. Perry, United States Navy. Volume II - with illustrations. (Anon, editors), pp. 331-332. Senate of the Thirty-third Congress, Second Session, Executive Document. House of Representatives, Washington.

Harvey, W.H. (1859). Phycologia Australica... Vol. 2. Lovell Reeve \& Co, London.

Harvey, W.H. (1860). Characters of new algae, chiefly from Japan and adjacent regions, collected by Charles Wright in the North Pacific Exploring Expedition under Captain James Rodgers. Proceedings of the American Academy of Arts and Sciences, 4: 327-335. Harvey, W.H. (1862). Phycologia australica...Vol. 4. Lovell Reeve \& Co, London. 
32

Hollenberg, G.J. (1942). An account of the species of Polysiphonia on the Pacific coast of North America. I. Oligosiphonia. American Journal of Botany, 29: 772-785.

Hollenberg, G.J. (1944). An account of the species of Polysiphonia on the Pacific coast of North America. II. Polysiphonia. American Journal of Botany, 31: 474-483.

Hollenberg, G. J. (1961). Marine red algae of Pacific Mexico, Part 5: The genus Polysiphonia. Pacific Naturalist, 2: 345-375.

Hollenberg, G.J. (1968a). An account of the species of Polysiphonia of the central and western tropical Pacific ocean. II Oligosiphonia. Pacific Science, 22: 56-98.

Hollenberg, G.J. (1968b). An account of the species of Polysiphonia of the central and western tropical Pacific ocean. I. Polysiphonia. Pacific Science, 22: 198-207.

Hollenberg, G. J. (1968c). An account of the species of the red alga Herposiphonia occurring in the Central and Western tropical Pacific Ocean. Pacific Science, 22: 536-559.

Hollenberg, G. J. \& Norris, J. N. (1977). The red alga Polysiphonia (Rhodomelaceae) in the Northern Gulf of California. Smithsonian Contributions to the Marine Sciences, 1: 1-21.

Hommersand, M. H. (1963). The morphology and classification of some Ceramiaceae and Rhodomelaceae. University of California Publications in Botany, 35: 165-366.

Hommersand M.H. (2007). Global biogeography and relationships of the Australian marine macroalgae. In Algae of Australia (McCarthy, P.M. \& Orchard, A.E., editors), 511-542. Australian Biological Resources Study, Canberra.

Hommersand, M.H. \& Fredericq, S. (1990). Sexual reproduction and cystocarp development. In: Biology of the red algae. (Cole, K.M. \& Sheath, R.G., editors), 305-346. Cambridge University Press, Cambridge.

Hooker, W. \& Harvey, W. H. (1845). Algae Novae Zelandiae... London Journal of Botany, 4: 521551.

Hudson, W. (1762). Flora anglica; exhibens plantas per regnum angliae sponte crescentes, distributas secundum systema sexuale: cum differentiis specierum, synonymis auctorum, 
nominibus incolarum, solo locorum, tempore florendi, officinalibus pharmacopoeorum. J. Nourse \& C. Moran, London.

Hurd, C.L., Harrison, P.J., Bischof, K. \& Lobban, C.S. (2014). Seaweed Ecology and Physiology. Second Edition. Cambridge University Press, Cambridge.

Iyengar, M.O.P. \& Balakrishnan, M.S. (1950). Morphology and cytology of Polysiphonia platycarpa Boerges. Proceedings of the Indian Academy of Science B, 31: 135-161.

Karsten, U., Sawall, T., Hanelt, D., Bischof, K., Figueroa, F. L., Flores-Moya, A. \& Wiencke, C. (1998). An inventory of UV-absorbing mycosporine-like amino acids in macroalgae from polar to warm-temperate regions. Botanica Marina, 41: 443-454.

Kearse, M., Moir, R., Wilson, A., Stones-Havas, S., Cheung, M., Sturrock, S., Buxton, S., Cooper, A., Markowitz, S., Duran, C., Thierer, T., Ashton, B., Mentjies, P. \& Drummond, A. (2012). Geneious Basic: an integrated and extendable desktop software platform for the organization and analysis of sequence data. Bioinformatics, 28:1647-1649.

Kim, M. S. (2003). Taxonomic reassessment of the genus Polysiphonia (Rhodomelaceae, Rhodophyta): morphology and reproduction of Neosiphonia decumbens and N. harlandii. Algae, 18: 107-119.

Kim, M. S. (2005). Taxonomy of a poorly documented alga, Neosiphonia savatieri Rhodomelaceae, Rhodophyta) from Korea. Nova Hedwigia, 81: 163-176.

Kim, M.S. \& Lee, I.K. (1999). Neosiphonia flavimarina gen. et sp. nov. with a taxonomic reassessment of the genus Polysiphonia (Rhodomelaceae, Rhodophyta). Phycological Research, 47: 271-281.

Kim, M. S. \& Abbott, I. A. (2006). Taxonomic notes on Hawaiian Polysiphonia, with transfer to Neosiphonia (Rhodomelaceae, Rhodophyta). Phycological Research, 54: 32-39.

Kim, M. S. \& Yang, E. C. (2006). Taxonomy and phylogeny of Neosiphonia japonica (Rhodomelaceae, Rhodophyta) based on $r b c \mathrm{~L}$ and $c p e \mathrm{~A} / \mathrm{B}$ gene sequences. Algae, 21: 287294. 
34

831 Kim, B. \& Kim, M.S. (2014). Three new species of Polysiphonia sensu lato (Rhodophyta) based 832 on the morphology and molecular evidence. Algae, 29: 183-195.

833 Kim, B. \& Kim, M.S. (2016). Neosiphonia yongpilii sp. nov. (Rhodomelaceae, Rhodophyta), 834 known as Neosiponia simplex from Korea, with an emphasis on cystocarp development. 835 Phycologia, 55: 323-332.

836 Kim, M. S., Lee, I. K. \& Boo, S. M. (1994). Morphological studies of the red alga Polysiphonia 837 morrowii Harvey on the Korean coast. The Korean Journal of Phycology, 9: 185-192.

838 Kim, M.-S., Maggs, C.A., McIvor, L. \& Guiry, M.D. (2000). Reappraisal of the type species of 839

Kirby, R.R. \& Reid, P.C. (2001). PCR from the CPR offers a historical perspective on marine population ecology. Journal of the Marine Biological Association of the United Kingdom, 81: $539-540$.

Kraft, G. T. \& Abbott, I. A. (2002). The anatomy of Neotenophycus ichthyosteus gen. et sp. nov. (Rhodomelaceae, Ceramiales), a bizarre red algal parasite from the central Pacific. European Journal of Phycology, 37: 269-278.

Kuntze, O. (1891). Revisio generum plantarum. Pars II. Arthur Felix, Dulau \& Co., U. Hoepli, Gust. A. Schechert, Charles Klincksieck, Leipzig, London, Milano, New York, Paris.

Kützing, F.T. (1863). Tabulae phycologicae; oder, Abbildungen der Tange. Vol. XIII. Gedruckt auf kosten des Verfassers (in commission bei W. Köhne), Nordhausen.

Kützing, F.T. (1864). Tabulae phycologicae; oder, Abbildungen der Tange. Vol. XIV. Gedruckt auf kosten des Verfassers (in commission bei W. Köhne), Nordhausen.

Kylin, H. (1941). Californische Rhodophyceen. Acta Universitatis Lundensis, 37(2):1-71.

Kylin, H. (1956). Die Gattungen der Rhodophyceen. CWK Gleerups Förlag, Lund.

Lam, W. D., García-Fernández, M. E., Aaboal, M., Vis, M. L. (2013). Polysiphonia subtilissima (Ceramiales, Rhodophyta) from freshwater habitats in North America and Europe is confirmed as conspecific with marine collections. Phycologia, 52: 156-160. 
35

857 Lartillot, N., Lepage, T. \& Blanquart, S. (2009). PhyloBayes 3: a Bayesian software package for 858 phylogenetic reconstruction and molecular dating. Bioinformatics, 25: 2286-2288.

859 Lee, Y. (2008). Marine Algae of Jeju. Academy Publication, Seoul.

860 Levring, T. (1941). Die Meeresalgen der Juan Fernandez-Inseln. Die Corallinaceen der Juan 861 Fernandez-Inseln. In The Natural History of Juan Fernandez and Easter Island (Skottsberg, 862 C., editor) Vol. 2, 601-670; 753-757. Almqvist \& Wiksells Boktryckeri, Uppsala. 863 Lüning, K. (1990). Seaweeds: their Environment, Biogeography and Ecophysiology. Wiley $864 \quad$ Interscience publications, New York.

865 Maggs, C.A. \& Hommersand, M.H. (1993). Seaweeds of the British Isles. Volume 1 Rhodophyta, 866 Part 3 A Ceramiales. Natural History Museum/HMSO, London.

867 Mamoozadeh, N.R. \& Freshwater, D.W. (2011). Taxonomic notes on Caribbean Neosiphonia and 868 Polysiphonia (Ceramiales, Florideophyceae): five species from Florida, USA and Mexico. 869 Botanica Marina, 54: 269-292.

870 Mamoozadeh, N.R. \& Freshwater, D.W. (2012). Polysiphonia sensu lato (Ceramiales, 871 Florideophyceae) species of Caribbean Panama including Polysiphonia lobophoralis sp. nov. 872 and Polysiphonia nuda sp. nov. Botanica Marina, 55: 317-347.

873 Masuda, M., Kudo, T., Kawaguchi, S. \& Guiry, M. D. (1995). Lectotypification of some marine 874 red algae described by W. H. Harvey from Japan. Phycological Research, 43: 191-202.

Masuda, M., Abe, T., Kawaguchi, S. \& Phang, S. M. (2001). Taxonomic notes on marine algae from Malaysia. VI. Five species of Ceramiales (Rhodophyceae). Botanica Marina, 44: 467-478.

McIvor, L., Maggs, C.A., Provan, J. \& Stanhope, M.J. (2001). rbcL sequences reveal multiple cryptic introductions of the Japanese red alga Polysiphonia harveyi. Molecular Ecology, 10: 911-919.

881 Millar, A. J. K. (1990). Marine red algae of the Coffs Harbour region, northern New South Wales. $882 \quad$ Australian Systematic Botany, 3: 293-593. 
36

883 Morrill, J.F. (1976). Comparative morphology and taxonomy of some dorsiventral and some 884 parasitic Rhodomelaceae. Thesis, University of North Carolina, Chapel Hill.

885 Muangmai, N., Yamagishi, Y., Maneekat, S \& Kaewsuralikhit, C. (2014). The new species 886 Neosiphonia thailandica sp. nov. (Rhodomelaceae, Rhodophyta) from the Gulf of Thailand. 887 Botanica Marina, 57: 459-467.

888 Nägeli, C. (1846). Über Polysiphonia und Herposiphonia. Zeitschrift für wissenschaftliche $889 \quad$ Botanik 4: 207-256. 890 Nam, K.W. \& Kang, P.J. (2012). Algal flora of Korea. Volume 4, Number 4. Rhodophyta: 891 Ceramiales: Rhodomelaceae: 18 genera including Herposiphonia. National Institute of 892 Biological Resources, Incheon.

893 Nam, K. W., Maggs, C. A., McIvor, L. \& Stanhope, M. J. (2000). Taxonomy and phylogeny of 894 Osmundea (Rhodomelaceae, Rhodophyta) in Atlantic Europe. Journal of Phycology, 36: $759-772$.

896 Navarro, N.P., Mansilla, A., Figueroa, F., Korbee, N., Jofre, J. \& Plastino, E. (2014). Short-term effects of solar UV radiation and $\mathrm{NO}_{3}{ }^{-}$supply on the accumulation of mycosporine-like amino acids in Pyropia columbina (Bangiales, Rhodophyta) under spring ozone depletion in the sub-Antarctic region, Chile. Botanica Marina, 57: 9-20.

Noda, M. \& Kitami, T. (1971). Some species of marine algae from Echigo Province facing the Japan Sea. Scientific Reports Niigata University, Ser. D. (Biology), 8: 35-52.

Norris, R. E. (1994). Some cumophytic Rhodomelaceae (Rhodophyta) occuring in Hawaiian surf. Phycologia, 33: 434-443.

Norris, J.N. (2014). Marine algae of the northern Gulf of California, II: Rhodophyta. Smithsonian Institution Scholarly Press, Washington D.C.

Okamura, K. (1912). Icones of Japanese Algae. Vol. II (10), pls. 96-100. Privately published, Tokyo. 
37

908 Parsons, M.J. (1975). Morphology and taxonomy of the Dasyaceae and the Lophothalieae

909 (Rhodomelaceae) of the Rhodophyta. Australian Journal of Botany, 23: 549-713.

910 Parsons, M. J. (1980). The morphology and taxonomy of Brongniartella Bory sensu Kylin 911 (Rhodomelaceae, Rhodophyta). Phycologia, 19: 273-295.

912 Phillips, L. E., Choi, H. G., Saunders, G. W. \& Kraft, G. T. (2000). The morphology, taxonomy 913 and molecular phylogeny of Heterocladia and Trigenea (Rhodomelaceae,

914 Rhodophyta),with delineation of the little known tribe Heterocladieae. Journal of 915 Phycology, 36: 199-219.

916 Price, I.R. \& Scott, F.J. (1992). The turf algal flora of the Great Barrier Reef. Part I. Rhodophyta. 917 Townsville, Australia: Botany Department, James Cook University.

918 Provan, J., Booth, D., Todd, N.P., Beatty, G.E. \& Maggs, C.A. (2008). Tracking biological 919 invasions in space and time: elucidating the invasive history of the green alga Codium $920 \quad$ fragile using old DNA. Diversity and Distributions, 14: 343-354.

921 Pueschel, C. M. (1990). Cell structure. In Biology of the red algae (Cole, K. M. \& Sheath, R. G., 922 editors), 7-41. Cambridge University Press, Cambridge.

923 Rambaut, A., Suchard, M.A., Xie, W., Drummond, A.J. (2013). Tracer MCMC Trace Analysis 924 Tool, Version v1.6.0. Available from: http://tree.bio.ed.ac.uk/software/tracer/ 925 Ribera, M. A. \& Boudouresque, C. F. (1995). Introduced marine plants, with special reference to macroalgae: mechanisms and impact. In Progress in Phycological Research (Round, F. E. \& Chapman, D. J., editors), 187-268. Biopress Ltd.

928 Ronquist, F., Teslenko, M., Mark, P. van der, Ayres, D., Darling, A., Höhna, S., Larget, B., Liu, 929 L., Suchard, M.A. \& Huelsenbeck, J.P. (2011). MrBayes 3.2: Efficient Bayesian 930 phylogenetic inference and model choice across a large model space. Systematic Biology, 61: 539-542. 
38

932 Savoie, A.M. \& Saunders, G.W. (2015). Evidence for the introduction of the Asian red alga 933 Neosiphonia japonica and its introgression with Neosiphonia harveyi (Ceramiales, 934 Rhodophyta) in the Northwest Atlantic. Molecular Ecology, 24: 5917-5937.

Savoie, A.M. \& Saunders, G.W. (2016). A molecular phylogenetic and DNA barcode assessment of the tribe Pterosiphonieae (Ceramiales, Rhodophyta) emphasizing the Northeast Pacific. Botany, 94: 917-939.

Saunders, G.W. \& McDevit, D.C. (2012). Methods for DNA barcoding photosynthetic protists emphasizing the macroalgae and diatoms. Methods in Molecular Biology, 858: 207-222. Saunders, G.W. \& Moore, T.E. (2013). Refinements for the amplification and sequencing of red algal DNA barcode and RedToL phylogenetic markers: a summary of current primers, profiles and strategies. Algae, 28: 31-43.

Schmitz, F. \& Falkenberg, P. (1897). Rhodomelaceae. In Die natürlichen Pflanzenfamilien nebst ihren Gattungen und wichtigeren Arten insbesondere den Nutzpflanzen unter Mitwirkung zahlreicher hervorragender Fachgelehrten, Teil 1, Abteilung 2. (Engler, A. \& Prantl, K. editors), 421-480. Verlag von Wilhelm Engelmann, Leipzig.

Segi, T. (1949). On the systematic position of the so-called Polysiphonia hakodatensis Yendo from Japan. Siebutsu, 14: 134-139.

Segi, T. (1951). Systematic study of the genus Polysiphonia from Japan and its vicinity. Journal of the Faculty of Fisheries, Prefectual University of Mie, 1: 169-272.

Setchell, W.A. (1926). Tahitian algae collected by W.A. Setchell, C.B. Setchell and H.E. Parks. University of California Publications in Botany, 12: 61-142.

Setchell, W. A. \& Gardner, N. L. (1924). XXIX Expedition of the California Academy of Sciences to the Gulf of California in 1921. The Marine Algae. Proceeding of the California Academy of Science, 4: 695-949.

Setchell, W. A. \& Gardner, N. L. (1930). Marine algae of the Revillagigedo Islands expedition in 1925. Proceedings of the California Academy of Sciences, 4: 109-215. 
39

958 Shameel, M. (1999). Melanothamnus afaqhusainii, a new red alga from the coast of Karachi.

959 Pakistan Journal of Botany, 31: 211-214.

960 Shameel, M. (2000). Further investigations on the red algae Melanothamnus afaqhusainii 961 (Ceramiales) from the coast of Pakistan. Pakistan Journal of Botany, 32: 15-26.

962 Shavit, L., Penny, D., Hendy, M.D. \& Holland, B.R. (2007). The problem of rooting rapid 963 radiations. Molecular Biology and Evolution, 24: 2400-2411.

964 Sherwood, A.R., Kurihara, A., Conklin, K.Y., Sauvage, T., \& Presting, G.G. (2010). The Hawaiian 965 Rhodophyta biodiversity survey (2006-2010): a summary of principal findings. BMC Plant $966 \quad$ Biology, 10: 258.

967 Silva, P. C., Basson, P. W. \& Moe, R. L. (1996). Catalogue of the benthic marine algae of the Indian Ocean. University of California Publications in Botany, 79: 1-1259.

Stamatakis, A. (2014). RAxML Version 8: A tool for phylogenetic analysis and post-analysis of large phylogenies. Bioinformatics, 30: 1312-1313.

Stegenga, H., Bolton, J.J. \& Anderson, R.J. (1997). Seaweeds of the South African west coast. Bolus Herbarium, University of Cape Town, Cape Town.

Stuercke, B. \& Freshwater, D.W. (2008). Consistency of morphological characters used to delimit Polysiphonia sensu lato species (Ceramiales, Florideophyceae): analyses of North Carolina, USA specimens. Phycologia, 47: 541-559.

Stuerke, B. \& Freshwater, D.W. (2010). Two new species of Polysiphonia (Ceramiales, Florideophyceae) from the western Atlantic. Botanica Marina, 53: 301-311.

Suhr, J.N. von (1831). Beschreibung einiger neuen Algen. Flora, 14: 673-687, 709-716, 725-731.

Thiers, B. [continuously updated]. Index Herbariorum: A global directory of public herbaria and associated staff. New York Botanical Garden's Virtual Herbarium. http://sweetgum.nybg.org/science/ih/.

Thorne, J.L. \& Kishino, H. (2002). Divergence time and evolutionary rate estimation with multilocus data. Systematic Biology, 51: 689-702. 
40

984 Uwai, S. \& Masuda, M. (1999). Kintarosiphonia (Rhodomelaceae, Ceramiales), a new red algal genus based on Pterosiphonia fibrillosa Okamura from Japan. Phycologia, 38: 225-233.

Womersley, H. B. S. (1979). Southern Australian species of Polysiphonia Greville (Rhodophyta). Australian Journal of Botany, 27: 459-528.

Womersley, H. B. S. (2003). The Marine Benthic Flora of Southern Australia. Rhodophyta. Part IIID. Ceramiales- Delesseriaceae, Sarcomeniaceae, Rhodomelaceae. Australian Biological Resources Study \& State Herbarium of South Australia, Canberra \& Adelaide.

Wulfen, F.X. (1789). Plantae rariores carinthiacae. In Collectanea ad botanicam, chemiam, et historiam naturalem, spectantia cum figuris (Jacquin, J.N., editor). Ex Officina Wappleriana, Vienna.

Wynne, M. J. \& Banaimoon, S. A. (1990). The occurrence of Jolyna laminarioides (Phaeophyta) in the Arabian Sea and the Indian Ocean and a new report of Melanothamnus somalensis (Rhodophyta). Botanica Marina, 33: 213-218.

Yang, E.U., Boo, S.M., Bhattacharya, D., Saunders, G.W., Knoll, A.H., Fredericq, S., Graf, L. \& Yoon, S.H. (2016). Divergence time estimates and the evolution of major lineages in the florideophyte red algae. Scientific Reports, 6: 21361.

Yoon, H.Y. (1986). A taxonomic study of genus Polysiphonia (Rhodophyta) from Korea. Korean Journal of Phycology, 1: 3-86.

Yoshida, T. (1998). Marine algae of Japan. Uchida Rokakuho Publishing Co., Tokyo.

Zuccarello, G.C., West, J.A., Kamiya, M. \& King, R.J. (1999). A rapid method to score plastid haplotypes in red seaweeds and its use in determining parental inheritance of plastids in the red alga Bostrychia (Ceramiales). Hydrobiologia, 401: 207-214. 
Table 1. Comparison of selected morphological characteristics among the Polysiphonia sensu stricto 1 and 2, Vertebrata, Carradoriella, Streblocladia, Polysiphonia schneideri and Melanothamnus clades.

\begin{tabular}{|c|c|c|c|c|c|c|}
\hline Feature & $\begin{array}{l}\text { Polysiphonia sensu } \\
\text { stricto } 1 \text { and } 2\end{array}$ & Vertebrata & $\begin{array}{l}\text { Carradoriella } \\
\text { clade }\end{array}$ & Streblocladia clade & $\begin{array}{l}\text { "Polysiphonia" } \\
\text { schneideri clade }\end{array}$ & Melanothamnus \\
\hline Thallus habit & $\begin{array}{l}\text { Erect; decumbent; } \\
\text { prostrate }\end{array}$ & $\begin{array}{l}\text { Erect; decumbent; } \\
\text { prostrate }\end{array}$ & Erect & Erect & Erect; decumbent & Erect; decumbent \\
\hline Rhizoid connection & Open & Cut off & Cut off & Cut off & Cut off & Cut off \\
\hline Pericentral cells & $\begin{array}{l}4 \text { (6-8 in } \\
\text { Bryocladia } \\
\text { cuspidata, clade 2) }\end{array}$ & $6-24$ & $5-16$ & $4-12$ & $4-7$ & $4-9$ \\
\hline Cortication & Absent & Absent / Present & Present & Present & Absent & Absent / Present \\
\hline Plastid arrangement & Scattered & Scattered & Scattered & Scattered & Scattered & Radial walls \\
\hline $\begin{array}{l}\text { Branch/trichoblast } \\
\text { arrangement }\end{array}$ & $\begin{array}{l}\text { With naked } \\
\text { segments }\end{array}$ & $\begin{array}{l}\text { On every segment } \\
\text { or with naked } \\
\text { segments }\end{array}$ & $\begin{array}{l}\text { On every segment } \\
\text { or with naked } \\
\text { segments }\end{array}$ & $\begin{array}{l}\text { With naked } \\
\text { segments }\end{array}$ & $\begin{array}{l}\text { With naked } \\
\text { segments }\end{array}$ & $\begin{array}{l}\text { On every segment } \\
\text { or with naked } \\
\text { segments }\end{array}$ \\
\hline $\begin{array}{l}\text { Branches in } \\
\text { trichoblast axils }\end{array}$ & No & Yes/No & Yes / No & No & Yes / No & No \\
\hline
\end{tabular}




\begin{tabular}{|c|c|c|c|c|c|c|}
\hline $\begin{array}{l}\text { Trichoblast cell } \\
\text { nuclei and } \\
\text { pigmentation }\end{array}$ & $\begin{array}{l}\text { Uninucleate; } \\
\text { Pigmentation } \\
\text { absent }\end{array}$ & $\begin{array}{l}\text { Multinucleate; } \\
\text { Pigmentation } \\
\text { absent (Present) }\end{array}$ & $\begin{array}{l}\text { Uninucleate; } \\
\text { Pigmentation } \\
\text { absent }\end{array}$ & Trichoblasts absent & $\begin{array}{l}\text { Uninucleate; } \\
\text { Pigmentation } \\
\text { absent }\end{array}$ & $\begin{array}{l}\text { Uninucleate; } \\
\text { Pigmentation } \\
\text { absent }\end{array}$ \\
\hline Branching pattern & $\begin{array}{l}\text { Spiral, } \\
\text { pseudodichotomous }\end{array}$ & $\begin{array}{l}\text { Spiral, } \\
\text { pseudodichotomous, } \\
\text { dorsiventral }\end{array}$ & Pseudodichotomous & $\begin{array}{l}\text { Dorsiventral, spiral, } \\
\text { pseudodichotomous }\end{array}$ & $\begin{array}{l}\text { Spiral, } \\
\text { pseudodichotomous }\end{array}$ & $\begin{array}{l}\text { Dorsiventral, spiral, } \\
\text { pseudodichotomous }\end{array}$ \\
\hline $\begin{array}{l}\text { Spermatangial } \\
\text { branches }\end{array}$ & $\begin{array}{l}\text { Replacing } \\
\text { trichoblasts (or on a } \\
\text { trichoblast branch } \\
\text { in P. devoniensis } \\
\text { and P. kapraunii), } \\
\text { with or without } \\
\text { sterile apical cells }\end{array}$ & $\begin{array}{l}\text { On a branch of } \\
\text { trichoblasts } \\
\text { (replacing them in } \\
V . \text { lanosa), } \\
\text { with/without sterile } \\
\text { apical cells }\end{array}$ & $\begin{array}{l}\text { On a branch of } \\
\text { trichoblasts, with } \\
\text { sterile apical cells }\end{array}$ & $\begin{array}{l}\text { Replacing } \\
\text { trichoblasts, } \\
\text { without sterile } \\
\text { apical cells }\end{array}$ & $\begin{array}{l}\text { On a branch of } \\
\text { trichoblasts, } \\
\text { with/without sterile } \\
\text { apical cells }\end{array}$ & $\begin{array}{l}\text { On a branch of } \\
\text { trichoblasts, } \\
\text { with/without sterile } \\
\text { apical cells }\end{array}$ \\
\hline Carpogonial branch & 4-celled & 4-celled & 4-celled & Unknown & 4-celled & 3-celled \\
\hline $\begin{array}{l}\text { Cystocarp } \\
\text { morphology }\end{array}$ & $\begin{array}{l}\text { Globular; ovoid; } \\
\text { urceolate }\end{array}$ & Globular; ovoid & Ovoid & Ovoid & Globular & Globular; ovoid \\
\hline Cells of the ostiole & Similar to the cells & Similar to the cells & Similar to the cells & Larger than cells & Similar to the cells & (Similar to) Larger \\
\hline
\end{tabular}




\section{Page 43 of 109}

\begin{tabular}{|c|c|c|c|c|c|c|}
\hline & below & below & below & below & below & than cells below \\
\hline Tetrasporangial rows & $\begin{array}{l}\text { Straight (slightly } \\
\text { spiral) }\end{array}$ & $\begin{array}{l}\text { Straight or spiral } \\
\text { (two per segment in } \\
\text { Ctenosiphonia) }\end{array}$ & Straight or spiral & Straight or spiral & Straight or spiral & (Straight) Spiral \\
\hline References & $\begin{array}{l}\text { This work, } 5,6,9 \text {, } \\
15,16,18,22 .\end{array}$ & $\begin{array}{l}\text { This work, } 1,2,3, \\
6,7,8 ; 16,18,20 \\
21,24\end{array}$ & This work, 16, 21. & This work, 2,3 . & $\begin{array}{l}\text { This work, 7, 13, } \\
18,22 \text {. }\end{array}$ & $\begin{array}{l}\text { This work, } 2,3,4, \\
6,9,10,11,12,14, \\
16,17,18,19,20, \\
21,22,23,24,25 .\end{array}$ \\
\hline
\end{tabular}

References: ${ }^{1}$ Abbott \& Hollenberg (1976); ${ }^{2}$ Adams (1991); ${ }^{3}$ Adams (1994); ${ }^{4}$ Bustamante et al. $\left(2013\right.$ b); ${ }^{5}$ Dawes \& Mathieson (2008); ${ }^{6}$ DíazTapia \& Bárbara (2013); ${ }^{7}$ Díaz-Tapia et al. (2013a); ${ }^{8}$ Díaz-Tapia et al. (2013b); ${ }^{9}$ Hollenberg (1942); ${ }^{10}$ Hollenberg (1968a); ${ }^{11}$ Hollenberg \& Norris (1977); ${ }^{12} \operatorname{Kim} \&$ Lee (1999); ${ }^{13} \operatorname{Kim} \&$ Kim (2014); ${ }^{14} \operatorname{Kim} \&$ Kim (2016); ${ }^{15}$ Kim et al. (1994); ${ }^{16}$ Maggs \& Hommersand (1993);

${ }^{17}$ Mamoozadeh \& Freshwater (2011); ${ }^{18}$ Mamoozadeh \& Freshwater (2012); ${ }^{19}$ Muangmai et al. (2014); ${ }^{20}$ Segi (1949); ${ }^{21}$ Stegenga et al. (1997); ${ }^{22}$ Stuercke \& Freshwater (2010); ${ }^{23}$ Uwai \& Masuda (1999); ${ }^{24}$ Womersley (2003); ${ }^{25}$ Yoon (1986). 
Table 2. Genus Vertebrata with new combinations resulting from the present study

\begin{tabular}{|c|c|}
\hline $\begin{array}{l}\text { Binomial in Vertebrata } \\
\text { Basionym } \\
\text { Synonyms }\end{array}$ & $\begin{array}{l}\text { Type material } \\
\text { Type locality }\end{array}$ \\
\hline $\begin{array}{l}\text { Vertebrata constricta (Womersley) Díaz-Tapia \& Maggs, comb. nov. } \\
\text { Polysiphonia constricta Womersley (1979, 497-498; Southern Australian species of Polysiphonia Greville } \\
\text { (Rhodophyta). Australian Journal of Botany, 27: 459-528) }\end{array}$ & $\begin{array}{l}\text { Holotype: AD A32927 } \\
\text { Kangaroo I., South Australia; } \\
\text { 21.xi.1968 }\end{array}$ \\
\hline $\begin{array}{l}\text { Vertebrata foetidissima (Cocks ex Bornet) Díaz-Tapia \& Maggs, comb. nov. } \\
\text { Polysiphonia foetidissima Cocks ex Bornet (1892, pp. 314-315; Les algues de P. K. A. Schousboe..... } \\
\text { Mémoires de la Société Nationale des Sciences naturelles et Mathématiques de Cherbourg, 28: 165- } \\
\text { 376.) }\end{array}$ & $\begin{array}{l}\text { Lectotype (Maggs \& Hommersand, } \\
\text { 1993): PC } 0146017 \\
\text { Plymouth, England; undated }\end{array}$ \\
\hline $\begin{array}{l}\text { Vertebrata isogona (Harvey) Díaz-Tapia \& Maggs, comb. nov. } \\
\text { Polysiphonia isogona Harvey (in Hooker 1855, p. 231; The botany of the Antarctic voyage.... Reeve, } \\
\text { London.) }\end{array}$ & $\begin{array}{l}\text { Lectotype (Womersley, 1979): BM } \\
1082304 \\
\text { Blind Bay, Cook's Straits, New } \\
\text { Zealand; viii.1849 }\end{array}$ \\
\hline
\end{tabular}




\section{Page 45 of 109}

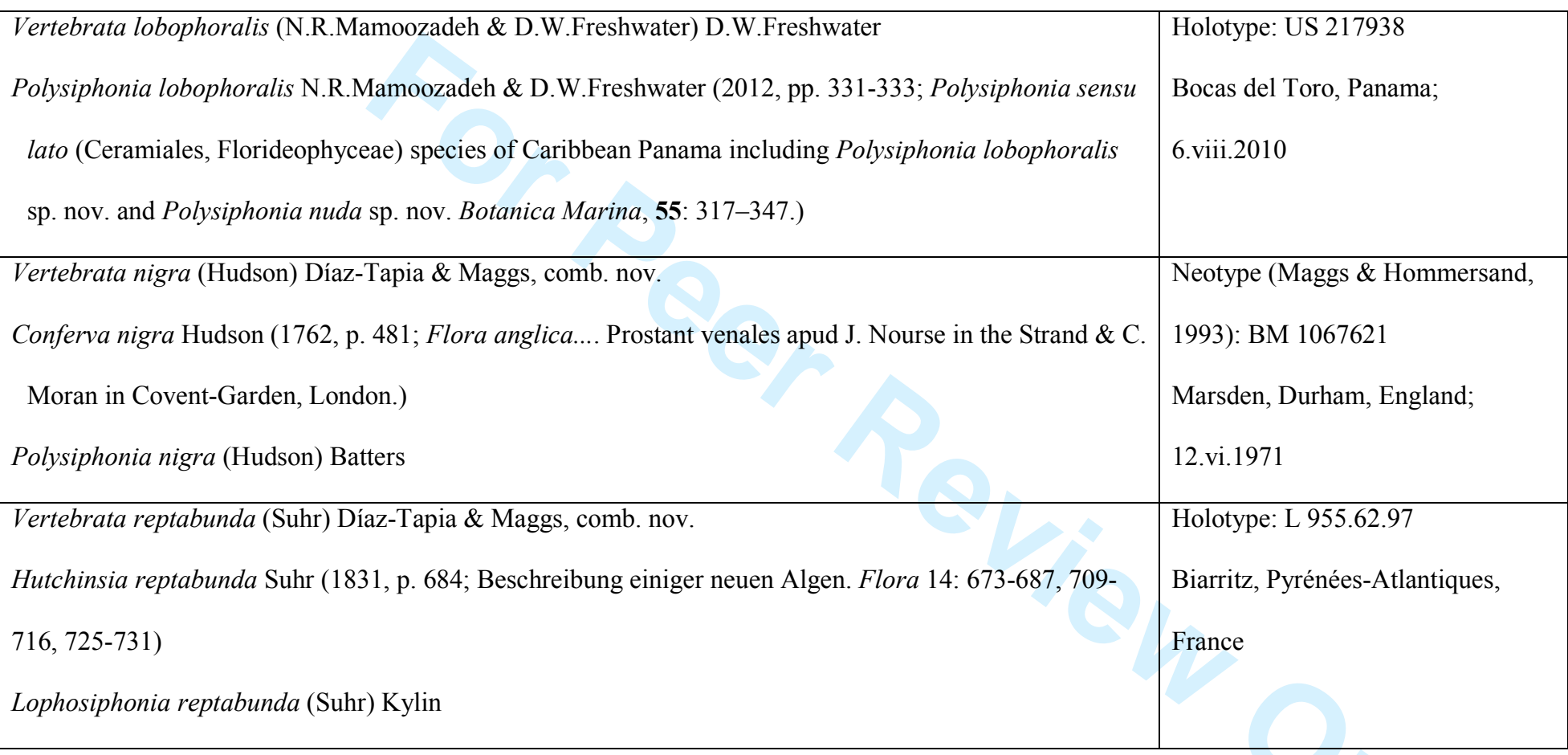


Table 3. Genus Vertebrata with resurrected names resulting from the present study.

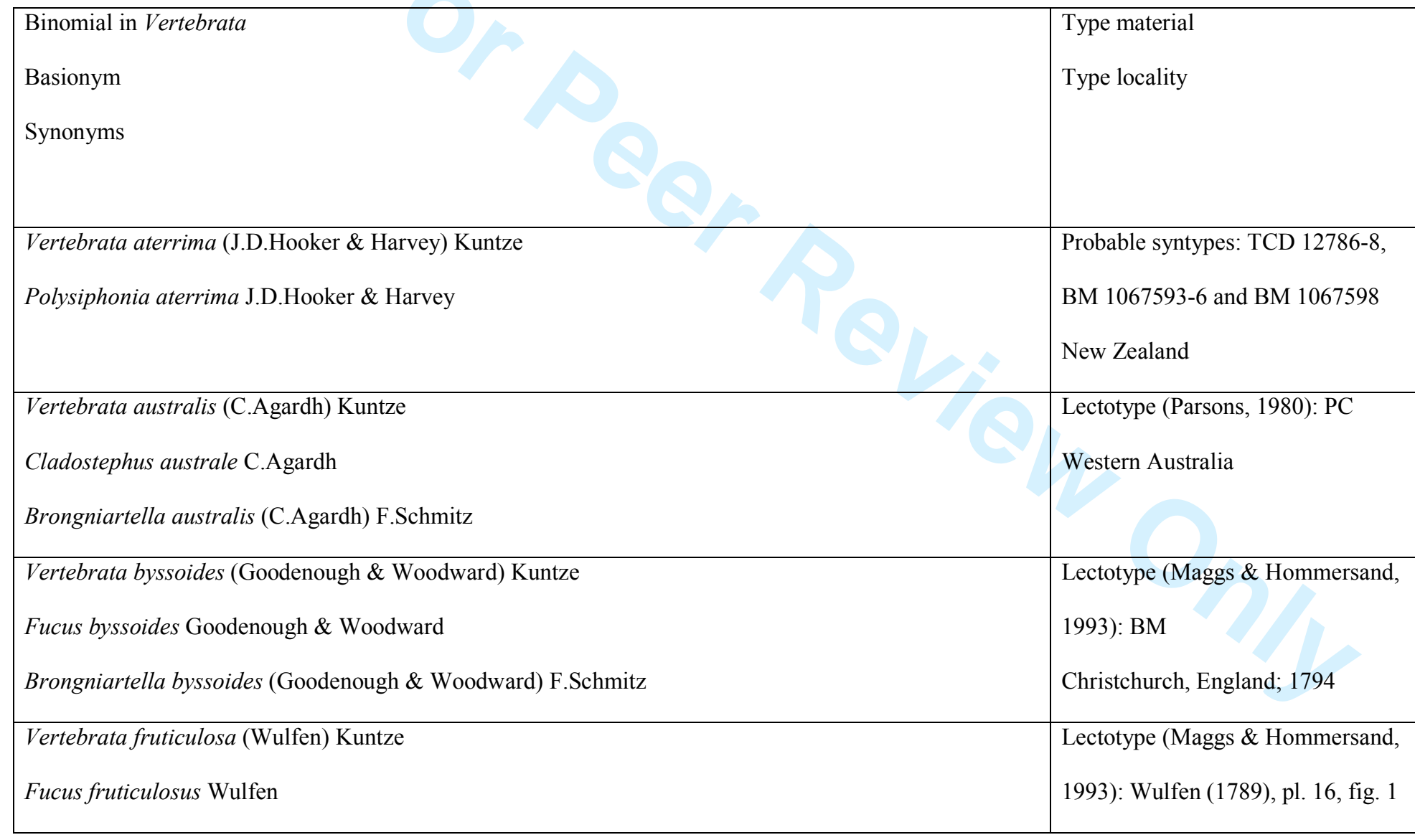

URL: http:/mc.manuscriptcentral.com/tejp Email: ejp@nhm.ac.uk 


\section{Page 47 of 109}

European Journal of Phycology

\begin{tabular}{|c|c|}
\hline Boergeseniella fruticulosa (Wulfen) Kylin & Trieste [Tergestum], Adriatic \\
\hline $\begin{array}{l}\text { Vertebrata fucoides (Hudson) Kuntze } \\
\text { Conferva fucoides Hudson } \\
\text { Polysiphonia fucoides (Hudson) Greville }\end{array}$ & $\begin{array}{l}\text { Neotype (Maggs \& Hommersand, } \\
\text { 1993): BM } 807101 \\
\text { Unlocalized, undated }\end{array}$ \\
\hline $\begin{array}{l}\text { Vertebrata furcellata (C.Agardh) Kuntze } \\
\text { Hutchinsia furcellata C.Agardh } \\
\text { Polysiphonia furcellata (C.Agardh) Harvey }\end{array}$ & $\begin{array}{l}\text { Lectotype (Maggs \& Hommersand, } \\
\text { 1993): LD } 40907 \\
\text { Brittany, France; undated }\end{array}$ \\
\hline $\begin{array}{l}\text { Vertebrata hypnoides (Welwitsch) Kuntze } \\
\text { Polysiphonia hypnoides Welwitsch ex J.Agardh } \\
\text { Ctenosiphonia hypnoides (Welwitsch ex J.Agardh) Falkenberg }\end{array}$ & $\begin{array}{l}\text { Holotype: LD Agardh's herbarium } \\
\text { no. } 39346 \\
\text { Lisbon, Portugal }\end{array}$ \\
\hline $\begin{array}{l}\text { Vertebrata lanosa (Linnaeus) T.A.Christensen } \\
\text { Fucus lanosus Linnaeus } \\
\text { Polysiphonia lanosa (Linnaeus) Tandy }\end{array}$ & $\begin{array}{l}\text { Holotype: LINN } 1274.23 \\
\text { Iceland, undated }\end{array}$ \\
\hline $\begin{array}{l}\text { Vertebrata simulans (Harvey) Kuntze } \\
\text { Polysiphonia simulans Harvey }\end{array}$ & $\begin{array}{l}\text { Lectotype (Maggs \& Hommersand, } \\
\text { 1993): BM-K } \\
\text { Devon, England; 20.v.1831 }\end{array}$ \\
\hline Vertebrata stimpsonii (Harvey) Kuntze & Holotype: TCD 11956 \\
\hline
\end{tabular}

URL: http:/mc.manuscriptcentral.com/tejp Email: ejp@nhm.ac.uk 


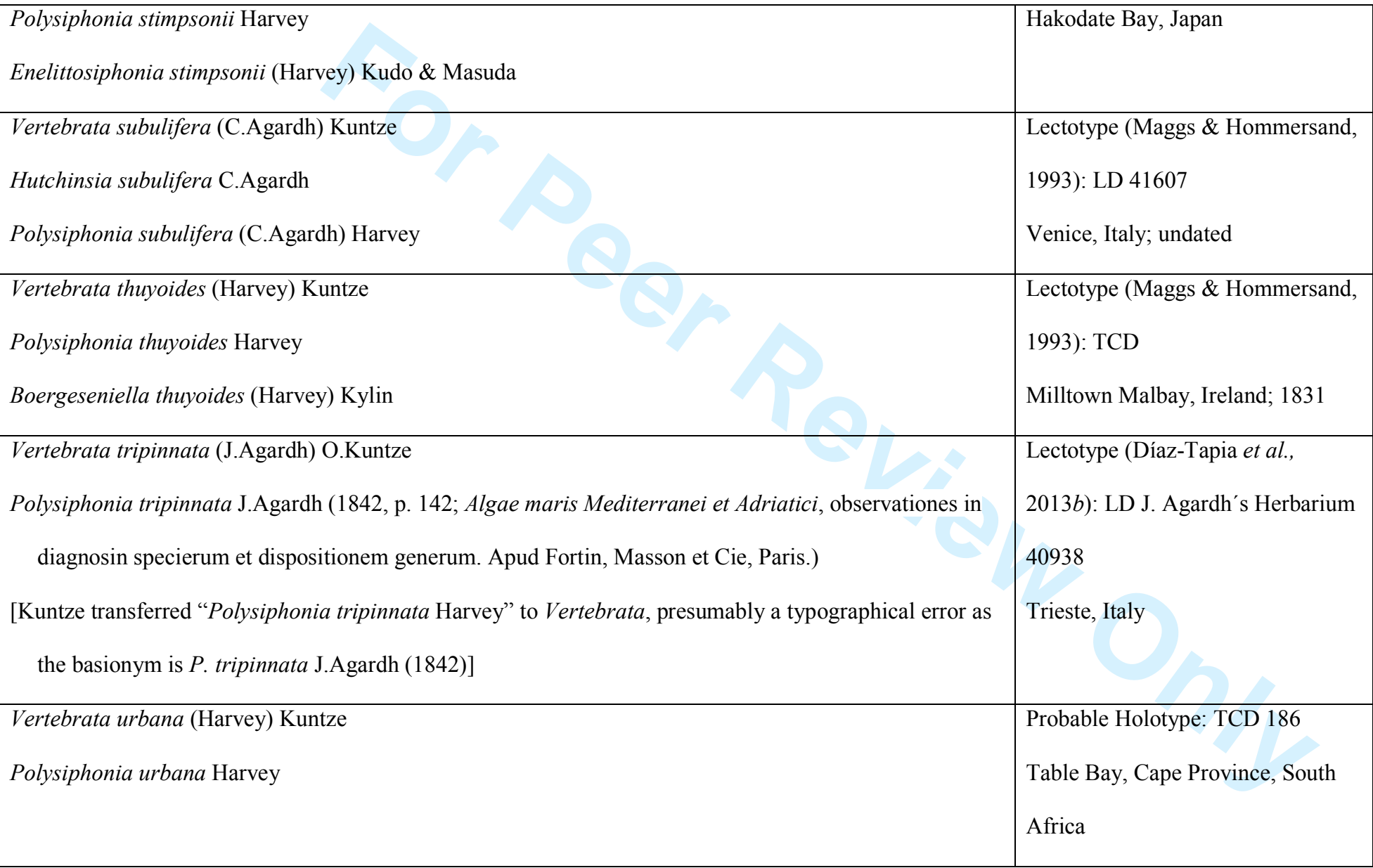




\section{Page 49 of 109}

\section{European Journal of Phycology}

49

Note: The positions of Polysiphonia paniculata in the $r b c \mathrm{~L}$ and $18 \mathrm{~S}$ trees are not congruent. This suggests that these two sequences, generated from samples from Chile and California, respectively (Table S1), were obtained from different species. The assignment of this species to the genus Vertebrata therefore requires further study to clarify the identity of the two published sequences. The type locality is Peru.

URL: http:/mc.manuscriptcentral.com/tejp Email: ejp@nhm.ac.uk 
Table 4. Genus Melanothamnus with new combinations resulting from the present study.

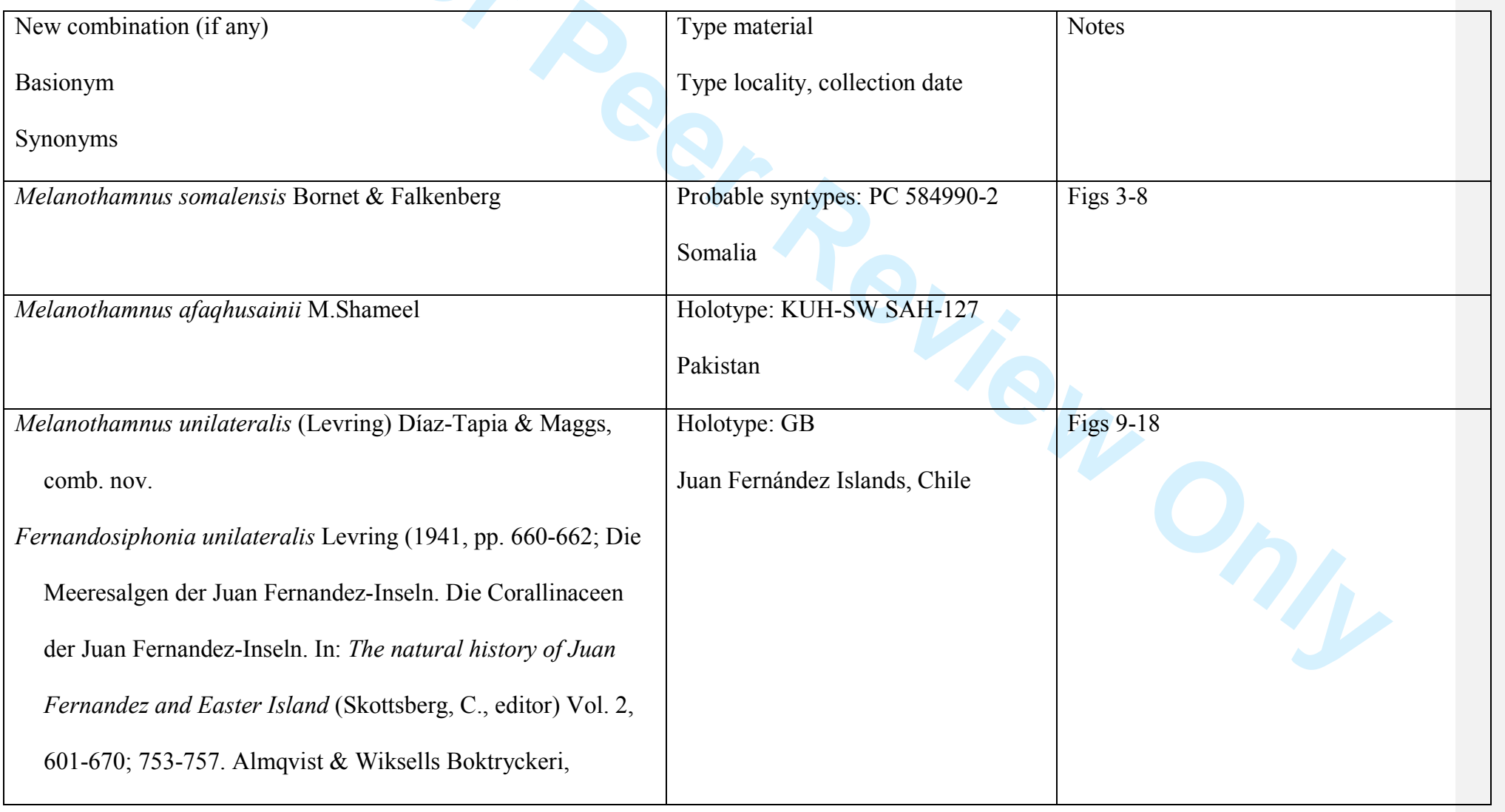




\section{Page 51 of 109}

\begin{tabular}{|c|c|c|}
\hline Uppsala) & & \\
\hline $\begin{array}{l}\text { Melanothamnus apiculatus (Hollenberg) Díaz-Tapia \& Maggs, } \\
\text { comb. nov. } \\
\text { Polysiphonia apiculata Hollenberg (1968a, p. 61; An account of } \\
\text { the species of Polysiphonia of the central and western tropical } \\
\text { Pacific ocean. II Oligosiphonia. Pacific Science, 22: 56-98) } \\
\text { Neosiphonia apiculata (Hollenberg) Masuda \& Kogame }\end{array}$ & $\begin{array}{l}\text { Holotype: US } 48522 \\
\text { O'ahu Island, Hawai'i; 30.vii.1959 }\end{array}$ & $\begin{array}{l}\text { 3-celled carpogonial branches (Kim \& } \\
\text { Abbott, 2006); plastid character } \\
\text { (Hollenberg 1968a; Fig. 9) }\end{array}$ \\
\hline $\begin{array}{l}\text { Melanothamnus bajacali (Hollenberg) Díaz-Tapia \& Maggs, } \\
\text { comb. nov. } \\
\text { Polysiphonia bajacali Hollenberg (1961, pp. 347-348; Marine } \\
\text { red algae of Pacific Mexico, Part 5: The genus Polysiphonia. } \\
\text { Pacific Naturalist, 2: 345-375) } \\
\text { Neosiphonia bajacali (Hollenberg) N.R.Mamoozadeh \& D.W. } \\
\text { Freshwater }\end{array}$ & $\begin{array}{l}\text { Holotype: AHFH } \\
\text { Isla Guadalupe, Baja California, } \\
\text { Mexico; 18.xii. } 1949\end{array}$ & $\begin{array}{l}\text { "Cell walls hyaline" (Hollenberg, 1961). } \\
\text { Molecular data available from Yucatan, } \\
\text { Mexico (Mamoozadeh \& Freshwater, } \\
\text { 2011) }\end{array}$ \\
\hline $\begin{array}{l}\text { Melanothamnus balianus (D.E.Bustamante, B.Y.Won \& } \\
\text { T.O.Cho) Díaz-Tapia \& Maggs, com. nov. } \\
\text { Neosiphonia baliana D.E.Bustamante, B.Y.Won \& T.O.Cho }\end{array}$ & $\begin{array}{l}\text { Holotype: CUK } 7937 \\
\text { Blue Lagoon beach, Padang Bai, } \\
\text { Karangasem, Bali, Indonesia; 27.iv. }\end{array}$ & $\begin{array}{l}\text { Molecular data from the type locality } \\
\text { (Bustamante et al., 2013b) }\end{array}$ \\
\hline
\end{tabular}




\begin{tabular}{|c|c|c|}
\hline $\begin{array}{l}\text { (2013 b, pp. 516-518; Neosiphonia baliana sp. nov. and } N \text {. } \\
\text { silvae sp. nov. (Rhodomelaceae, Rhodophyta) from } \\
\text { Bali, Indonesia. Botanica Marina, 56: 515-524) }\end{array}$ & 2012. & \\
\hline $\begin{array}{l}\text { Melanothamnus blandii (Harvey) Díaz-Tapia \& Maggs, comb. } \\
\text { nov. } \\
\text { Polysiphonia blandii Harvey (1862, pl. 184; Phycologia } \\
\text { australica.... Vol. 4. Lovell Reeve \& Co, London) }\end{array}$ & $\begin{array}{l}\text { Lectotype (Womersley, 1979): TCD } \\
\text { Brighton, Port Phillip, Victoria, } \\
\text { Australia }\end{array}$ & $\begin{array}{l}\text { 3-celled carpogonial branches; plastid } \\
\text { character. Molecular data available from } \\
\text { the type locality (this work) }\end{array}$ \\
\hline $\begin{array}{l}\text { Melanothamnus cheloniae (Hollenberg \& J.N.Norris) Díaz- } \\
\text { Tapia \& Maggs, comb. nov. } \\
\text { Polysiphonia sphaerocarpa var. cheloniae Hollenberg \& } \\
\text { J.N.Norris (1977, p. 16-17; The red alga Polysiphonia } \\
\text { (Rhodomelaceae) in the Northern Gulf of California. } \\
\text { Smithsonian Contributions to the Marine Sciences, 1: 1-21.) } \\
\text { Neosiphonia cheloniae (Hollenberg \& J.N.Norris) J.N.Norris }\end{array}$ & $\begin{array}{l}\text { Holotype: US } 160602 \\
\text { Sonora, Gulf of California, Mexico; } \\
\text { 21.i.1974 }\end{array}$ & $\begin{array}{l}\text { Plastid character (Hollenberg \& Norris, } \\
\text { 1977; fig. 4B) }\end{array}$ \\
\hline $\begin{array}{l}\text { Melanothamnus collabens (C.Agardh) Díaz-Tapia \& Maggs, } \\
\text { comb. nov. } \\
\text { Hutchinsia collabens C.Agardh (1824, p. 153; Systema algarum. }\end{array}$ & $\begin{array}{l}\text { Syntypes: LD Agardh herbarium } \\
\text { 40885-40887 and 40890-40898; } \\
\text { Cádiz, Spain }\end{array}$ & $\begin{array}{l}\text { 3-celled carpogonial branches; plastid } \\
\text { character; molecular data available from } \\
\text { the type locality (Díaz-Tapia \& Bárbara, }\end{array}$ \\
\hline
\end{tabular}




\section{Page 53 of 109}

European Journal of Phycology

\begin{tabular}{|l|l|l|}
\hline $\begin{array}{l}\text { Berlinginiana, Lundae) } \\
\text { Polysiphonia collabens (C.Agardh) Kützing } \\
\text { Streblocladia collabens (C.Agardh) Falkenberg } \\
\text { Neosiphonia collabens (C.Agardh) Díaz-Tapia \& Bárbara }\end{array}$ & 2013) \\
\hline $\begin{array}{l}\text { Melanothamnus concinnus (Hollenberg) Díaz-Tapia \& Maggs, } \\
\text { comb. nov. }\end{array}$ & Holotype: US 61210; \\
$\begin{array}{l}\text { Polysiphonia concinna Hollenberg (1944, pp. 474-475; An } \\
\text { account of the species of Polysiphonia on the Pacific coast of }\end{array}$ & La Jolla, California, USA; \\
$\begin{array}{l}\text { North America. II. Polysiphonia. American Journal of Botany, } \\
\text { 31: 474-483) } \\
\text { Polysiphonia johnstonii var. concinna } \text { (Hollenberg) Hollenberg } \\
\text { Neosiphonia concinna (Hollenberg) J.N.Norris }\end{array}$ & the type material \\
\hline $\begin{array}{l}\text { Melanothamnus decumbens (T.Segi) Díaz-Tapia \& Maggs, } \\
\text { comb. nov. }\end{array}$ & Holotype: SAP 25880; \\
$\begin{array}{l}\text { Polysiphonia decumbens T.Segi (1951, p. 218; Systematic study } \\
\text { of the genus Polysiphonia from Japan and its vicinity. Journal } \\
\text { of the Faculty of Fisheries, Prefectual University of Mie, 1: }\end{array}$ & Japan; vi.1948. & \\
\hline
\end{tabular}




\begin{tabular}{|c|c|c|}
\hline $\begin{array}{l}\text { 169-272) } \\
\text { Neosiphonia decumbens (T.Segi) M.-S.Kim \& I.K.Lee }\end{array}$ & & \\
\hline $\begin{array}{l}\text { Melanothamnus ecorticatus (R.E.Norris) Díaz-Tapia \& Maggs, } \\
\text { comb. nov. } \\
\text { Fernandosiphonia ecorticata R.E.Norris (1994, p. 434; Some } \\
\text { cumophytic Rhodomelaceae (Rhodophyta) occuring in } \\
\text { Hawaiian surf. Phycologia 33: 434-443) }\end{array}$ & $\begin{array}{l}\text { Holotype: BISH } 630042 \\
\text { Keokea Bay, Hawai' i; v.1990 }\end{array}$ & $\begin{array}{l}\text { Plastid character; ostiolar cells larger than } \\
\text { other pericarpial cells (Abbott, 1999) }\end{array}$ \\
\hline $\begin{array}{l}\text { Melanothamnus eastwoodiae (Setchell \& N.L.Gardner) Díaz- } \\
\text { Tapia \& Maggs, comb. nov. } \\
\text { Polysiphonia eastwoodiae Setchell \& N.L.Gardner (1930, p. } \\
\text { 161, as P. eastwoodae; Marine algae of the Revillagigedo } \\
\text { Islands expedition in 1925. Proceedings of the California } \\
\text { Academy of Sciences, 4: 109-215) } \\
\text { Neosiphonia eastwoodae (Setchell \& N.L.Gardner) Xiang Si- } \\
\text { duan }\end{array}$ & $\begin{array}{l}\text { Holotype: CAS } 173674 \\
\text { Islas Revillagigedo }\end{array}$ & $\begin{array}{l}\text { Plastid character observed in type } \\
\text { material }\end{array}$ \\
\hline Melanothamnus ferulaceus (Suhr ex J.Agardh) Díaz-Tapia \& & Type materials are in LD, J.Agardh's & Plastid character in Panama and Brazil. \\
\hline
\end{tabular}




\begin{tabular}{|c|c|c|}
\hline $\begin{array}{l}\text { Maggs, comb. nov. } \\
\text { Polysiphonia ferulacea Suhr ex J.Agardh (1863, p. 980; Species } \\
\text { Genera et Ordines Algarum..... C.W.K. Gleerup, Lundae) } \\
\text { Neosiphonia ferulacea (Suhr ex J.Agardh) S.M.Guimarães \& } \\
\text { M.T.Fujii }\end{array}$ & $\begin{array}{l}\text { Herbarium (not seen) } \\
\text { Atlantic Mexico; North America; } \\
\text { Guadeloupe; Hawaiian Islands; } \\
\text { Marquesas Islands; Australia }\end{array}$ & $\begin{array}{l}\text { Molecular data from Panama } \\
\text { (Mamoozadeh \& Freshwater, 2012; } \\
\text { Guimarâes et al., 2004) }\end{array}$ \\
\hline $\begin{array}{l}\text { Melanothamnus fibrillosus (Okamura) Díaz-Tapia \& Maggs, } \\
\text { comb. nov. } \\
\text { Pterosiphonia fibrillosa Okamura (1912, p. 172; Icones of } \\
\text { Japanese Algae. Vol. II (10). Privately published, Tokyo) } \\
\text { Kintarosiphonia fibrillosa (Okamura) S. Uwai \& Masuda }\end{array}$ & $\begin{array}{l}\text { Lectotype (Uwai \& Masuda, 1999): } \\
\text { SAP } \\
\text { Shirahama, Chiba Prefecture, Japan; } \\
\text { undated }\end{array}$ & $\begin{array}{l}\text { 3-celled carpogonial branches, plastid } \\
\text { character, cells surrounding the ostiole } \\
\text { much larger than the cells below (Uwai \& } \\
\text { Masuda, 1999, figs. 18, 19). }\end{array}$ \\
\hline $\begin{array}{l}\text { Melanothamnus flavimarinus (M.-S.Kim \& I.K.Lee) Díaz-Tapia } \\
\text { \& Maggs, comb. nov. } \\
\text { Neosiphonia flavimarina M.-S.Kim \& I.K.Lee (1999, p. 272; } \\
\text { Neosiphonia flavimarina gen. et sp. nov. with a taxonomic } \\
\text { reassessment of the genus Polysiphonia (Rhodomelaceae, } \\
\text { Rhodophyta). Phycological Research, 47: 271-281) }\end{array}$ & $\begin{array}{l}\text { Holotype: SNU IBA001 } \\
\text { Bangpo, Anmyondo, Korea; } \\
\text { 17.vii.1988. }\end{array}$ & $\begin{array}{l}\text { 3-celled carpogonial branches; plastid } \\
\text { character (Kim \& Lee, 1999, fig. 5). } \\
\text { Molecular data available from the type } \\
\text { locality (Kim \& Yang, 2006) }\end{array}$ \\
\hline Melanothamnus forfex (Harvey) Díaz-Tapia \& Maggs & Lectotype (Womersley, 1979): TCD & 3-celled carpogonial branches; plastid \\
\hline
\end{tabular}




\begin{tabular}{|c|c|c|}
\hline $\begin{array}{l}\text { nov. } \\
\text { Polysiphonia forfex Harvey (1859, pl. XCVI; Phycologia } \\
\text { Australica.... Vol. 2. Lovell Reeve \& Co, London) }\end{array}$ & $\begin{array}{l}\text { 15353-4 } \\
\text { Rottnest Island, Western Australia }\end{array}$ & $\begin{array}{l}\text { character, molecular data available from } \\
\text { the type locality (this work) }\end{array}$ \\
\hline $\begin{array}{l}\text { Melanothamnus gorgoniae (Harvey) Díaz-Tapia \& Maggs, } \\
\text { comb. nov. } \\
\text { Polysiphonia gorgoniae Harvey (1853, p. 39; Nereis boreali- } \\
\text { americana.... Smithsonian Contributions to Knowledge, 5: [i- } \\
\text { ii], [1]-258, pls XIII-XXXVI) }\end{array}$ & $\begin{array}{l}\text { Syntypes: TCD 12801-4, NY } \\
900637-8 \\
\text { Key West, Florida, U.S.A }\end{array}$ & $\begin{array}{l}\text { 3-celled carpogonial branches observed } \\
\text { in Brazil (Guimaraes, et al., 2004); } \\
\text { plastid character observed in type } \\
\text { material (this work) }\end{array}$ \\
\hline Neosiphonia gorgoniae (Harvey) S.M.Guimarães \& M.T.Fujii & & \\
\hline $\begin{array}{l}\text { Melanothamnus harlandii (Harvey) Díaz-Tapia \& Maggs, comb. } \\
\text { nov. } \\
\text { Polvsiphonia harlandii Harvev }(1860, \text { p. } 330 \text {; Characters of new }\end{array}$ & $\begin{array}{l}\text { Probable syntypes: TCD } 11955, \text { US } \\
56848 \\
\text { Hong Kong }\end{array}$ & $\begin{array}{l}\text { 3-celled carpogonial branches. Molecular } \\
\text { data available from Korea (Kim, 2003; } \\
\text { Kim \& Yang, 2006) }\end{array}$ \\
\hline $\begin{array}{l}\text { algae.... Proceedings of the American Academy of Arts and } \\
\text { Sciences, 4: 327-335) } \\
\text { Neosiphonia harlandii (Harvey) M.S.Kim \& I.K.Lee }\end{array}$ & & \\
\hline $\begin{array}{l}\text { Melanothamnus harveyi (Bailey) Díaz-Tapia \& Maggs, comb. } \\
\text { nov. }\end{array}$ & $\begin{array}{l}\text { Lectotype (Maggs \& Hommersand, } \\
\text { 1993): TCD } 12810\end{array}$ & $\begin{array}{l}\text { 3-celled carpogonial branches (this } \\
\text { work); plastid character. Molecular data }\end{array}$ \\
\hline
\end{tabular}




\section{Page 57 of 109}

European Journal of Phycology

\begin{tabular}{|c|c|c|}
\hline $\begin{array}{l}\text { Polysiphonia harveyi Bailey (1848, p. 38; Continuation of the } \\
\text { list of localities of algae in the United States. Proceedings of } \\
\text { the American Academy of Arts and Sciences, 4: 327-335) } \\
\text { Neosiphonia harveyi (Bailey) M.-S.Kim, H.-G.Choi, Guiry \& } \\
\text { G.W.Saunders }\end{array}$ & $\begin{array}{l}\text { Bailey; Stonington, Connecticut, } \\
\text { USA; vii. } 1847\end{array}$ & $\begin{array}{l}\text { available from the type locality (McIvor } \\
\text { et al., 2001) }\end{array}$ \\
\hline $\begin{array}{l}\text { Melanothamnus hawaiiensis (Hollenberg) Díaz-Tapia \& Maggs, } \\
\text { comb. nov. } \\
\text { Polysiphonia hawaiiensis Hollenberg (1968 a, pp. 66-67; An } \\
\text { account of the species of Polysiphonia of the central and } \\
\text { western tropical Pacific ocean. II Oligosiphonia. Pacific } \\
\text { Science, 22: 56-98.) } \\
\text { Neosiphonia hawaiiensis (Hollenberg) M.-S.Kim \& I.A.Abbott }\end{array}$ & $\begin{array}{l}\text { Holotype: US } 48524 \\
\text { Waikiki beach, O'ahu Island, } \\
\text { Hawai' i; } 21 . \text { i. } 1963\end{array}$ & $\begin{array}{l}\text { 3-celled carpogonial branches (Kim \& } \\
\text { Abbott, 2006). Plastid character (Abbott, } \\
\text { 1999, fig. 122C) }\end{array}$ \\
\hline $\begin{array}{l}\text { Melanothamnus incomptus (Harvey) Díaz-Tapia \& Maggs, } \\
\text { comb. nov. } \\
\text { Polysiphonia incompta Harvey (1847, p. 44; Nereis australis.... } \\
\text { Reeve Brothers, London) }\end{array}$ & $\begin{array}{l}\text { Probable holotype: TCD } 192 \\
\text { False Bay, Cape Province, South } \\
\text { Africa }\end{array}$ & $\begin{array}{l}\text { Plastid character. Molecular data } \\
\text { available from the type locality (this } \\
\text { work) }\end{array}$ \\
\hline Melanothamnus japonicus (Harvey) Díaz-Tapia \& Maggs, & Lectotype (Masuda et al., 1995): & Plastid character (this work); 3-celled \\
\hline
\end{tabular}




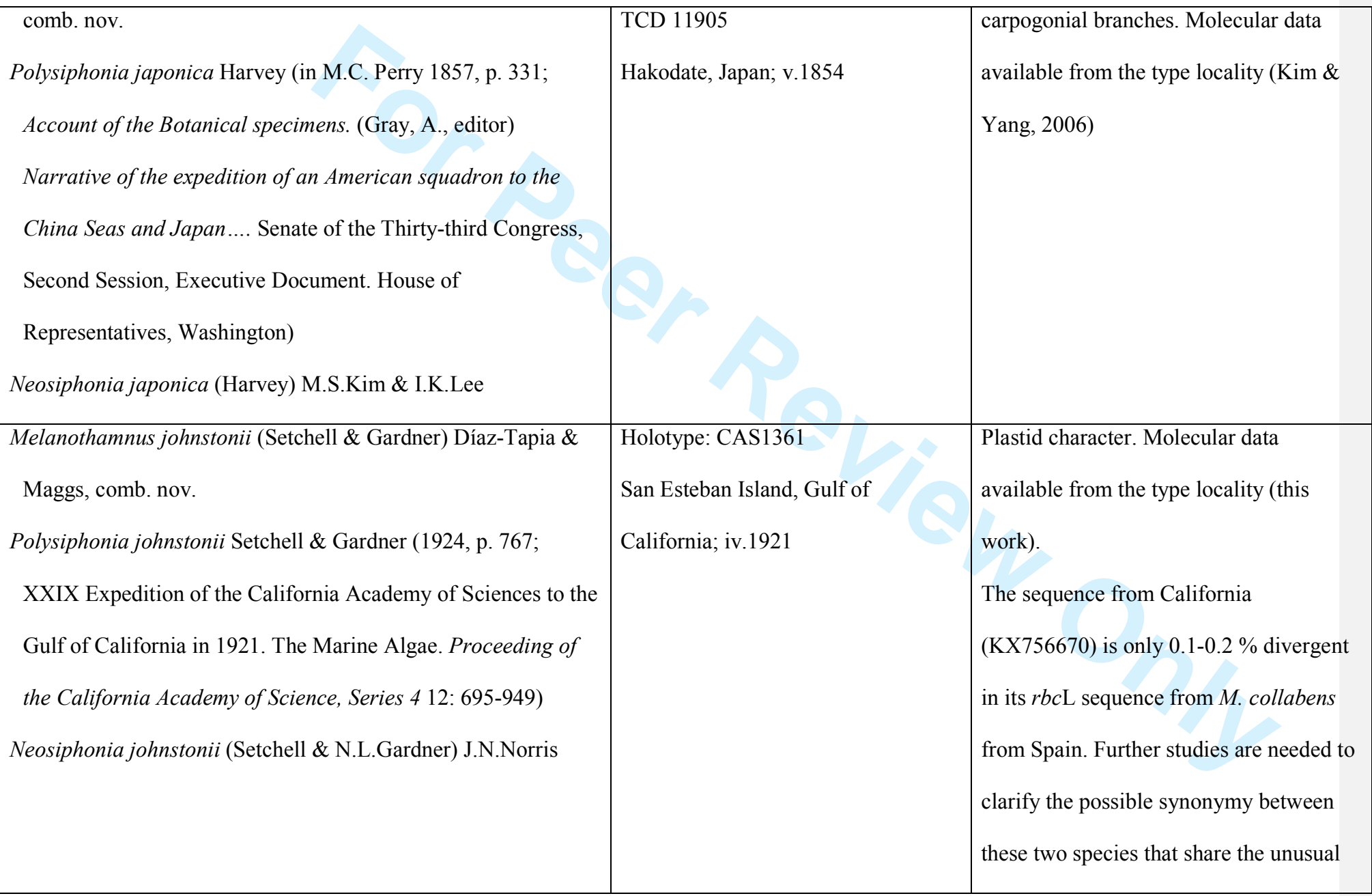




\section{Page 59 of 109}

European Journal of Phycology

\begin{tabular}{|c|c|c|}
\hline & & $\begin{array}{l}\text { character of having (5-) } 6 \text { pericentral } \\
\text { cells. }\end{array}$ \\
\hline $\begin{array}{l}\text { Melanothamnus nudus (N.R.Mamoozadeh \& D.W.Freshwater) } \\
\text { D.W.Freshwater } \\
\text { Polysiphonia nuda N.R.Mamoozadeh \& D.W.Freshwater (2012, } \\
\text { p. 335; Polysiphonia sensu lato (Ceramiales, Florideophyceae) } \\
\text { species of Caribbean Panama including Polysiphonia } \\
\text { lobophoralis sp. nov. and Polysiphonia nuda sp. nov. Botanica } \\
\text { Marina, 55: 317-347) }\end{array}$ & $\begin{array}{l}\text { Holotype: US } 211334 \\
\text { Parque de Juventud, Calle Primero, } \\
\text { Colon, Caribbean coast of Panama; } \\
\text { 20.v.2009 }\end{array}$ & $\begin{array}{l}\text { Molecular data available from the type } \\
\text { locality (Mamoozadeh \& Freshwater, } \\
\text { 2012) }\end{array}$ \\
\hline $\begin{array}{l}\text { Melanothamnus peruviensis (D.E.Bustamante, B.Y.Won, } \\
\text { M.E.Ramirez \& T.O.Cho) Díaz-Tapia \& Maggs, comb. nov. } \\
\text { Neosiphonia peruviensis D.E.Bustamante, B.Y.Won, } \\
\text { M.E.Ramirez \& T.O.Cho (2012, p. 360; Neosiphonia } \\
\text { peruviensis sp. nov. (Rhodomelacea, Rhodophyta) from the } \\
\text { Pacific coast of South America. Botanica Marina, 55: 359-366) }\end{array}$ & $\begin{array}{l}\text { Holotype: CUK } 7976 \\
\text { Lagunillas, Pisco, Ica, southern coast } \\
\text { of Lima, Peru; 21.viii. } 2008\end{array}$ & $\begin{array}{l}\text { Plastid character. Molecular data } \\
\text { available from the type locality } \\
\text { (Bustamante } \text { et al., 2012, fig. 10) }\end{array}$ \\
\hline $\begin{array}{l}\text { Melanothamnus platycarpus (Børgesen) Díaz-Tapia \& Maggs, } \\
\text { comb. nov. }\end{array}$ & $\begin{array}{l}\text { Probable syntypes: BM } 1067681 \text { and } \\
106760\end{array}$ & $\begin{array}{l}\text { 3-celled carpogonial branches; plastid } \\
\text { character (Iyengar \& Balakrishnan, 1949, }\end{array}$ \\
\hline
\end{tabular}




\begin{tabular}{|c|c|c|}
\hline $\begin{array}{l}\text { Polysiphonia platycarpa Børgesen (1934, p. 23; Some Indian } \\
\text { Rhodophyceae especially from the shores of the Presidency of } \\
\text { Bombay-IV. Bulletin of Miscellaneous Information, Royal } \\
\text { Botanic Gardens, Kew, 1934: 1-30) }\end{array}$ & Bombay, India; 19.xii.1927 & fig. 1) \\
\hline $\begin{array}{l}\text { Melanothamnus pseudovillum (Hollenberg) Díaz-Tapia \& } \\
\text { Maggs, comb. nov. } \\
\text { Polysiphonia pseudovillum Hollenberg (1968 a, p. 73; An } \\
\text { account of the species of Polysiphonia of the central and } \\
\text { western tropical Pacific ocean. II Oligosiphonia. Pacific } \\
\text { Science, 22: 56-98) }\end{array}$ & $\begin{array}{l}\text { Holotype: US 61232; } \\
\text { North Island, Johnston Islands; } \\
\text { 22.vi.1965 }\end{array}$ & $\begin{array}{l}\text { Cell walls "hyaline" (Hollenberg, } 1968 \\
\text { a). Molecular data available from } \\
\text { Panama (Mamoozadeh \& Freshwater, } \\
\text { 2011) }\end{array}$ \\
\hline $\begin{array}{l}\text { Melanothamnus ramireziae (D.E.Bustamante, B.Y.Won \& } \\
\text { T.O.Cho) Díaz-Tapia \& Maggs, comb. nov. } \\
\text { Neosiphonia ramirezii D.E.Bustamante, B.Y.Won \& T.O.Cho } \\
\text { (2013a, Neosiphonia ramirezii sp. nov. (Rhodomelaceae, } \\
\text { Rhodophyta) from Peru. Algae, 28: 73-82.) }\end{array}$ & $\begin{array}{l}\text { Holotype: CUK } 6511 \\
\text { Lagunillas, Pisco, Ica, Peru; } \\
\text { 21.viii.2008. }\end{array}$ & $\begin{array}{l}\text { Plastid character, 3-celled carpogonial } \\
\text { branches. Molecular data available from } \\
\text { the type locality (Bustamante et al., } \\
\text { 2013a, fig. 1f) }\end{array}$ \\
\hline $\begin{array}{l}\text { Melanothamnus silvae (D.E.Bustamante, B.Y.Won \& T.O.Cho) } \\
\text { Díaz-Tapia \& Maggs, comb. nov. }\end{array}$ & $\begin{array}{l}\text { Holotype: CUK } 7976 \\
\text { Geger, Nusadua, Bali, Indonesia; }\end{array}$ & $\begin{array}{l}\text { Plastid character. Molecular data } \\
\text { available from the type locality }\end{array}$ \\
\hline
\end{tabular}




\section{Page 61 of 109}

European Journal of Phycology

61

\begin{tabular}{|c|c|c|}
\hline $\begin{array}{l}\text { Neosiphonia silvae D.E.Bustamante, B.Y.Won \& T.O.Cho } \\
\text { (2013b, pp. 518-520; Neosiphonia baliana sp. nov. and N. } \\
\text { silvae sp. nov. (Rhodomelaceae, Rhodophyta) from } \\
\text { Bali, Indonesia. Botanica Marina, 56: 515-524) }\end{array}$ & 26.iv.2012 & (Bustamante et al., 2013b, figs 22-23) \\
\hline $\begin{array}{l}\text { Melanothamnus simplex (Hollenberg) Díaz-Tapia \& Maggs, } \\
\text { comb. nov. } \\
\text { Polysiphonia simplex Hollenberg, (1942, p. 782; An account of } \\
\text { the species of Polysiphonia on the Pacific coast of North } \\
\text { America. I. Oligosiphonia. American Journal of Botany, 29: } \\
772-785 \text { ) } \\
\text { Neosiphonia simplex (Hollenberg) Y.-P.Lee }\end{array}$ & $\begin{array}{l}\text { Holotype: US } 61238 \\
\text { Laguna Beach, Orange County, } \\
\text { California, U.S.A; } 14 . v .1937\end{array}$ & $\begin{array}{l}\text { Plastid character. Molecular data } \\
\text { available from the type locality (this } \\
\text { work). } \\
R b c \mathrm{~L} \text { sequence not incuded in our } \\
\text { phylogeny because it is only } 1 \% \\
\text { divergent from } N \text {. ramirezii. }\end{array}$ \\
\hline $\begin{array}{l}\text { Melanothamnus sphaerocarpus (Børgesen) Díaz-Tapia \& } \\
\text { Maggs, comb. nov. } \\
\text { Polysiphonia sphaerocarpa Børgesen (1918, p. 271; The marine } \\
\text { algae of the Danish West Indies. Part 3. Rhodophyceae (4). } \\
\text { Dansk Botanisk Arkiv, 3: 241-304.) } \\
\text { Neosiphonia sphaerocarpa (Børgesen) M.-S.Kim \& I.K.Lee }\end{array}$ & $\begin{array}{l}\text { Isotypes: US , C } \\
\text { Store Nordsidebugt, St. Thomas, } \\
\text { Virgin Islands }\end{array}$ & $\begin{array}{l}\text { Plastid character. Molecular data } \\
\text { available from Florida (Mamoozadeh \& } \\
\text { Freshwater, 2011, fig. 18) }\end{array}$ \\
\hline
\end{tabular}

URL: http:/mc.manuscriptcentral.com/tejp Email: ejp@nhm.ac.uk 


\begin{tabular}{|c|c|c|}
\hline $\begin{array}{l}\text { Melanothamnus strictissimus (J.D.Hooker \& Harvey) Díaz- } \\
\text { Tapia \& Maggs, comb. nov. } \\
\text { Polysiphonia strictissima J.D.Hooker \& Harvey (1845, p. 538; } \\
\text { Algae Novae Zelandiae.... London Journal of Botany, 4: 521- } \\
\text { 551.) }\end{array}$ & $\begin{array}{l}\text { Probable syntype: BM } 561312 \\
\text { New Zealand }\end{array}$ & $\begin{array}{l}\text { Plastid character (this work). Molecular } \\
\text { data available from the type locality } \\
\text { (Stuercke \& Freshwater, 2010) }\end{array}$ \\
\hline $\begin{array}{l}\text { Melanothamnus thailandicus (N.Muangmai \& } \\
\text { C.Kaewsuralikhit) Díaz-Tapia \& Maggs, comb. nov. } \\
\text { Neosiphonia thailandica N.Muangmai \& C.Kaewsuralikhit } \\
\text { (2014, pp. 460-461; The new species Neosiphonia thailandica } \\
\text { sp. nov. (Rhodomelaceae, Rhodophyta) from the Gulf of } \\
\text { Thailand. Botanica Marina, 57: 459-467) }\end{array}$ & $\begin{array}{l}\text { Holotype: KUMF-SRC 03-011-1 } \\
\text { Sri Racha Harbor, Chon Buri, } \\
\text { Thailand; 11.iii.2011 }\end{array}$ & $\begin{array}{l}\text { 3-celled carpogonial branches. Molecular } \\
\text { data available from the type locality } \\
\text { (Muangmai et al., 2014) }\end{array}$ \\
\hline $\begin{array}{l}\text { Melanothamnus yongpilii (B.Kim \& M.-S.Kim) Díaz-Tapia \& } \\
\text { Maggs, comb. nov. } \\
\text { Neosiphonia yongpilii B.Kim \& M.-S.Kim (2016, pp. 324-325; } \\
\text { Neosiphonia yongpilii sp. nov. (Rhodomelaceae, Rhodophyta), } \\
\text { known as Neosiphonia simplex from Korea, with an emphasis } \\
\text { on cystocarp development. Phycologia, 55: 323-332) }\end{array}$ & $\begin{array}{l}\text { Holotype: JNUB 140704-101 } \\
\text { Jongdal, Jeju Island, Korea; } \\
\text { 04.iv.2014 }\end{array}$ & $\begin{array}{l}\text { 3-celled carpogonial branches; plastid } \\
\text { character. Molecular data available from } \\
\text { the type locality (Kim \& Kim, 2016, fig. } \\
\text { 14) }\end{array}$ \\
\hline
\end{tabular}




\section{Page 63 of 109}

\section{European Journal of Phycology}

63

Note: Here we include only species that we can confidently assign to this genus (i.e., we have examined type material or suitable pictures of the type material showing the plastid character and/or sequences are available from the type locality or nearby).

URL: http:/mc.manuscriptcentral.com/tejp Email: ejp@nhm.ac.uk 
Table 5. New combinations in Melanothamnus made for formal reasons (because the current genus is here placed in synonymy with

Melanothamnus) although type material has not been examined

\begin{tabular}{|l|l|l|}
\hline Binomial in Melanothamnus (if any) & Type material & Notes \\
Basionym & Type locality & \\
Synonyms & & \\
\hline $\begin{array}{l}\text { Melanothamnus hancockii (Dawson) Díaz-Tapia \& Maggs, comb. } \\
\text { nov. }\end{array}$ & Holotype: LAM EYD629c & Plastid character. Molecular data from \\
Polysiphonia hancockii E.Y.Dawson (1944, pp. 331-332; The & & Japan (this work) \\
marine algae of the Gulf of California. Allan Hancock Pacific & & \\
Expeditions 3: 189-432) & & \\
Fernandosiphonia hancockii (Dawson) R.E.Norris & & \\
\hline Melanothamnus masonii (Setchell \& N.L.Gardner) Díaz-Tapia \& $16 . i i .1940$ & Holotype: CAS 173618 & \\
Maggs, comb. nov. & Isla Guadalupe, México; iv.1925 & \\
\hline
\end{tabular}

URL: http:/mc.manuscriptcentral.com/tejp Email: ejp@nhm.ac.uk 


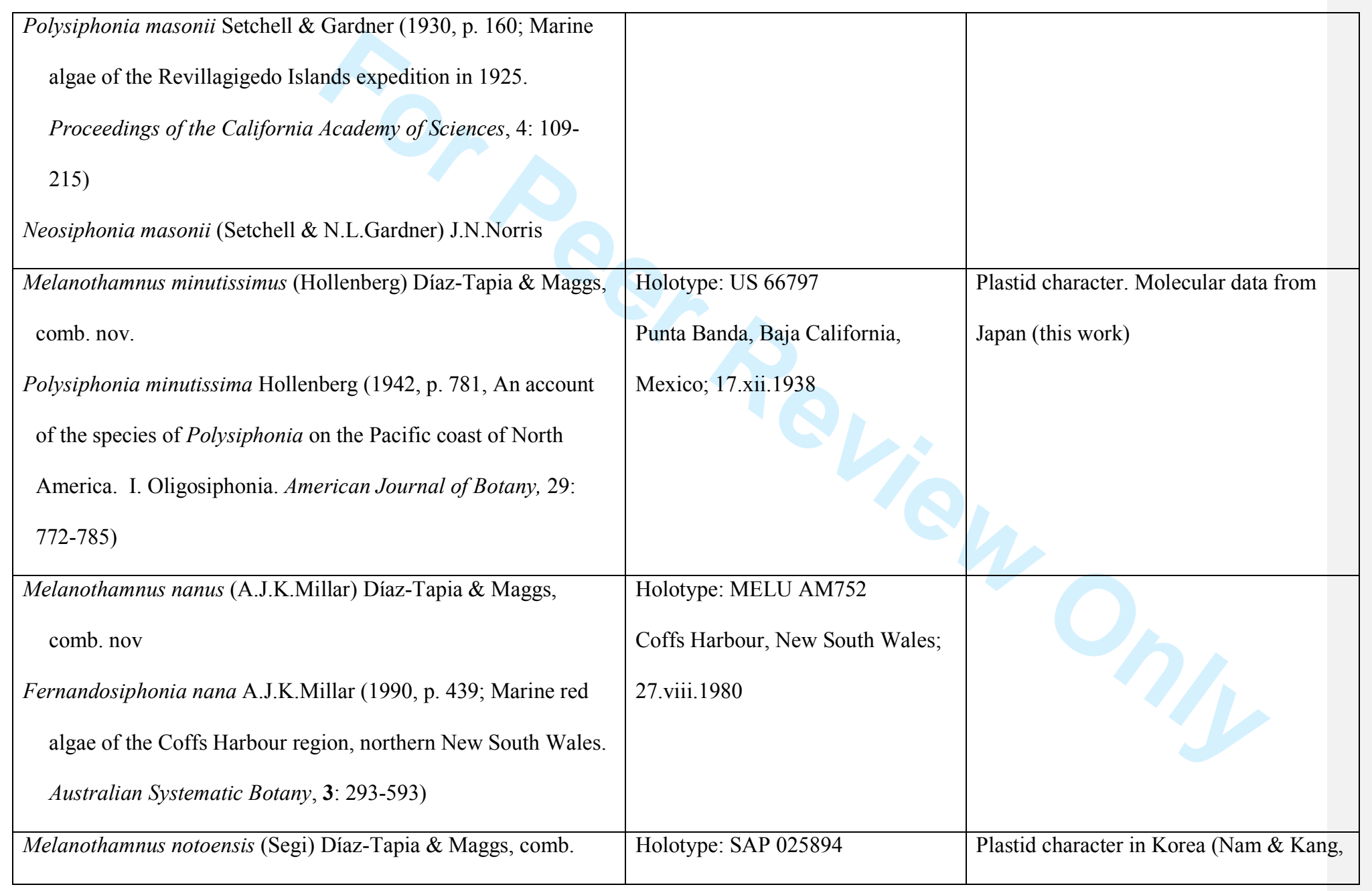




\begin{tabular}{|l|l|l|}
\hline nov. & Shibagaki, Ishikawa Prefecture, & 2012; fig. 47E) \\
$\begin{array}{l}\text { Polysiphonia notoensis Segi (1951, p. 266; Systematic study of } \\
\text { the genus Polysiphonia from Japan and its vicinity. Journal of } \\
\text { the Faculty of Fisheries, Prefectual University of Mie, 1: 169- }\end{array}$ & Japan; 9.vii.1947 & \\
272) & & \\
Neosiphonia notoensis (Segi) M.S.Kim \& I.K.Lee & Holotype: L 4082747 & \\
\hline $\begin{array}{l}\text { Melanothamnus polyphysus (Kützing) Díaz-Tapia \& Maggs, } \\
\text { comb. nov. }\end{array}$ & Vieillard; New Caledonia; undated & \\
Polysiphonia polyphysa Kützing (1863, p. 20; Tabulae \\
$\begin{array}{l}\text { phycologicae; oder, Abbildungen der Tange. Vol. XIII. } \\
\text { Gedruckt auf kosten des Verfassers (in commission bei W. }\end{array}$
\end{tabular}




\begin{tabular}{|c|c|c|}
\hline $\begin{array}{l}\text { Faculty of Fisheries, Prefectual University of Mie, 1: 169-272) } \\
\text { Neosiphonia porrecta (Segi) Y.-P. Lee }\end{array}$ & & \\
\hline $\begin{array}{l}\text { Melanothamnus savatieri (Hariot) Díaz-Tapia \& Maggs, comb. } \\
\text { nov. } \\
\text { Polysiphonia savatieri Hariot (1891, p. 226; Liste des algues } \\
\text { marines rapportés de Yokoska (Japon) par M. le Dr Savatier. } \\
\text { Mémoires de la Société nationale des sciences naturelles de } \\
\text { Cherbourg, 27: 211-230) } \\
\text { Neosiphonia savatieri (Hariot) M.S.Kim \& I.K.Lee } \\
\text { Melanothamnus sparsus (Setchell) Díaz-Tapia \& Maggs, comb. } \\
\text { nov. } \\
\text { Lophosiphonia sparsa Setchell (1926, p. 103; Tahitian algae } \\
\text { collected by W.A. Setchell, C.B. Setchell and H.E. Parks. } \\
\text { University of California Publications in Botany, 12: 61-142) } \\
\text { Polysiphonia sparsa (Setchell) Hollenberg } \\
\text { Neosiphonia sparsa (Setchell) I.A.Abbott }\end{array}$ & $\begin{array}{l}\text { Lectotype (Kim, 2005): PC } \\
0011879 \\
\text { Yokosuka, Kanagawa Prefecture, } \\
\text { Japan }\end{array}$ & $\begin{array}{l}\text { 3-celled carpogonial branches in } \\
\text { Malaysia (Masuda et al., 2001). } \\
\text { Molecular data available from Korea } \\
\text { (Phillips et al., 2000) }\end{array}$ \\
\hline Melanothamnus teradomariensis (M.Noda) Díaz-Tapia \& Maggs, & Holotype: Herbarium Niigata & Molecular data available from Korea \\
\hline
\end{tabular}




\begin{tabular}{|l|l|l|}
\hline comb. nov. & University & (Bárbara et al., 2013) \\
Polysiphonia teradomariensis M.Noda (in Noda, M. \& Kitami, T. & Echigo Province, Japan; 28.xi.1968 & \\
1971, 47; Some species of marine algae from Echigo Province \\
facing the Japan Sea. Scientific Reports Niigata University, Ser. \\
$\begin{array}{l}\text { D. (Biology), 8: } 35-52 \text { ) } \\
\text { Polysiphonia japonica var. teradomariensis (M.Noda) H.Y.Yoon } \\
\text { Neosiphonia teradomariensis (M.Noda) M.-S.Kim \& I.K.Lee }\end{array}$ & & \\
\hline $\begin{array}{l}\text { Melanothamnus tongatensis (Harvey ex Kützing) Díaz-Tapia \& } \\
\text { Maggs, comb. nov. }\end{array}$ & Holotype: L 4083619 & \\
Polysiphonia tongatensis Harvey ex Kützing, (1864, p. 14; & Tonga, Friendly Islands; undated & (Mamoozadeh \& Freshwater, 2011) \\
$\begin{array}{l}\text { Tabulae phycologicae; oder, Abbildungen der Tange. Vol. XIV. } \\
\text { Gedruckt auf kosten des Verfassers (in commission bei W. } \\
\text { Köhne), Nordhausen) }\end{array}$ & & \\
Neosiphonia tongatensis (Harvey ex Kützing) M.-S.Kim \& & & \\
I.K.Lee & & \\
\hline $\begin{array}{l}\text { Melanothamnus upolensis (Grunow) Díaz-Tapia \& Maggs, comb. } \\
\text { nov. }\end{array}$ & Syntypes: W & \\
\hline
\end{tabular}




\section{Page 69 of 109}

European Journal of Phycology

\begin{tabular}{|c|c|c|}
\hline $\begin{array}{l}\text { Polysiphonia upolensis Grunow (1874, p. 49; Algen der Fidschi-, } \\
\text { Tonga- und Samoa-Inseln, gesammelt von Dr. E. Graeffe. } \\
\text { Journal des Museum Godeffroy, 3: 23-50) } \\
\text { Neosiphonia upolensis (Grunow) M.S.Kim \& Boo }\end{array}$ & & \\
\hline $\begin{array}{l}\text { Melanothamnus yendoi (T.Segi) Díaz-Tapia \& Maggs, comb. nov. } \\
\text { Polysiphonia yendoi Segi (1951, p. 211; Systematic study of the } \\
\text { genus Polysiphonia from Japan and its vicinity. Journal of the } \\
\text { Faculty of Fisheries, Prefectual University of Mie, 1: 169-272) } \\
\text { Neosiphonia yendoi (Segi) M.-S.Kim \& I.K.Lee }\end{array}$ & $\begin{array}{l}\text { Holotype: SAP } 0258883 \\
\text { Muroran, Hokkaido, Japan; } \\
\text { 30.iv.1935 }\end{array}$ & $\begin{array}{l}\text { Molecular data available from Korea } \\
\text { (Bárbara et al., 2013) }\end{array}$ \\
\hline $\begin{array}{l}\text { Neosiphonia saccorhiza (F.S.Collins \& Hervey) J.M.C.Nunes \& } \\
\quad \text { S.M.Guimarães, nom. inval. } \\
\text { Lophosiphonia saccorhiza F.S.Collins \& Hervey } \\
\text { Polysiphonia saccorhiza (F.S.Collins \& Hervey) Hollenberg }\end{array}$ & $\begin{array}{l}\text { Isotypes: NY, Collins Herbarium } \\
\text { Gibbet Island, Bermuda }\end{array}$ & $\begin{array}{l}\text { Transfer to Melanothamnus is not made } \\
\text { here as N. saccorhiza is an invalid } \\
\text { combination (the basionym was not } \\
\text { cited), and the phylogenetic affinities of } \\
\text { Lophosiphonia saccorhiza are unknown. }\end{array}$ \\
\hline
\end{tabular}


Figure legends

Fig. 1. Phylogenetic tree estimated with $\mathrm{ML}$ analysis of $r b c \mathrm{~L}$ sequences. Values at nodes indicate bootstrap support (BP)/posterior probability (PP) (only shown if $>$ 60/0.6). Branches marked with an asterisk received 100\% (BP)/1.00 (PP) support. Species names printed in bold correspond to type species of genera.

Fig. 2. Phylogenetic tree estimated with ML analysis of $18 \mathrm{~S}$ sequences. Values at nodes indicate bootstrap support/posterior probability (only shown if $>60 \% / 0.6 \mathrm{PP}$ ). Branches marked with an asterisk received 100\%/1.00 PP support. Species names printed in bold correspond to type species of genera.

Figs 3-8. Melanothamnus somalensis, the type species of Melanothamnus. Fig. 3. Herbarium specimen MICH 662774. Fig. 4. Apical part of a specimen with alternately arranged branches. Figs 5-6. Apices of branches with (Fig. 5) or without (Fig. 6) abundant trichoblasts. Fig. 7. Apex of a lateral branch with trichoblasts. Fig. 8. Surface view of cells with the plastids lying exclusively on radial walls while the outer walls appear transparent (arrows). Scale bars: Fig. 3, 6 cm; Fig. 4, 1 mm; Figs 5 and 6, 350 $\mu \mathrm{m}$; Fig. 7, $200 \mu \mathrm{m}$; Fig. 8, $100 \mu \mathrm{m}$.

Figs 9-18. Fernandosiphonia unilateralis type material, the type species of Fernandosiphonia. Fig. 9. Herbarium specimen. Figs 10-11. Branches unilaterally arranged. Fig. 12. Axis with scar cells of trichoblasts (arrows). Figs 13-14. Surface view of pericentral cells with plastids lying only on the radial walls, so that the outer walls appear transparent (Fig. 13, arrows) and cells have a dark flank (Fig. 14). Fig. 15. 
71

Young spermatangial branch formed on the first dichotomy of a trichoblast, remaining the other vegetative branch (arrow). Fig. 16. Procarp $(\mathrm{su}=$ supporting cell; $\mathrm{cp}=$ carpogonium). Fig. 17. Cystocarp. Fig. 18. Tetrasporangia arranged in short spiral series. Scale bars: Fig. 9, 3 cm; Fig. 10, 2 mm; Fig. 11, $450 \mu$ m; Figs 12, 14, 17 and 18, $100 \mu \mathrm{m}$; Figs 13 and 15, $40 \mu \mathrm{m}$; Fig. 16, $20 \mu \mathrm{m}$.

Figs 19-24. Rhizoid anatomy in the Polysiphonieae. In open connection with pericentral cells in Polysiphonia stricta (Fig. 19, Polysiphonia sensu stricto clade 1). Cut off from pericentral cells in P. foetidissima (Fig. 20, Vertebrata clade), P. denudata (Fig. 21, Carradoriella clade), Polysiphonia sp. (Fig. 22, Streblocladia clade), P. schneideri (Fig. 23, P. schneideri clade) and P. incompta (Fig. 24, Melanothamnus clade). Scale bars: Figs 19-23, $100 \mu \mathrm{m}$; Fig. 24, $500 \mu \mathrm{m}$.

Figs 25-39. Plastid arrangement in the Polysiphonieae. Scattered against all cell walls of the pericentral cells in Polysiphonia stricta (Figs 25-26, Polysiphonia sensu stricto clade 1), Vertebrata lanosa (Figs 27-28, Vertebrata clade), P. virgata (Figs 29-30, Carradoriella clade), Polysiphonia sp. (Fig. 31, Streblocladia clade) and P. schneideri (Figs 32-33, P. schneideri clade). Lying exclusively on the radial walls of the pericentral cells in species of the Melanothamnus clade: Neosiphonia collabens (Figs 34-35), N. harveyi (Figs 36-38) and P. forfex (Fig. 39). Scale bars: Figs 25, 27, 29, 38 and 39, $500 \mu \mathrm{m}$; Figs 26, 28 and 30, $800 \mu \mathrm{m}$; Figs 31, 32, 34, 35 and 37, $100 \mu \mathrm{m}$; Fig. 33, $300 \mu \mathrm{m}$; Fig, 36, $50 \mu \mathrm{m}$.

Figs 40-46. Trichoblast nuclei (arrows) in the Polysiphonieae. Uninucleate trichoblast cells in Polysiphonia scopulorum (Fig. 40, Polysiphonia sensu stricto clade 1), P. 
denudata (Fig. 44, Carradoriella clade), P. schneideri (Fig. 45, P. schneideri clade) and P. blandii (Fig. 46, Melanothamnus clade). Multinucleate trichoblast cells in species of the Vertebrata clade: P. nigra (Fig. 41), Boergeseniella fruticulosa (Fig. 42) and $P$. foetidissima (Fig. 43). Scale bars: Figs 40-43, $60 \mu \mathrm{m}$, Fig. 44, $30 \mu \mathrm{m}$; Fig. 45, $20 \mu \mathrm{m}$; Fig. 46, $100 \mu \mathrm{m}$.

Figs 47-52. Spermatangial branches in the Polysiphonieae. Replacing trichoblasts and with sterile apical filaments in Polysiphonia stricta (Fig. 47, Polysiphonia sensu stricto clade 1). Replacing trichoblasts and lacking sterile apical cells in Vertebrata lanosa (Fig. 48, Vertebrata clade). On a branch of a trichoblast and with sterile apical cells in P. fucoides (Fig. 49, Vertebrata clade), P. denudata (Fig. 50, Carradoriella clade), $P$. schneideri (Fig. 51, P. schneideri clade) and Neosiphonia harveyi (Fig. 52, Melanothamnus clade). Scale bars: $100 \mu \mathrm{m}$. Arrows show the apical sterile cells and arrowheads the sterile branch of fertile trichoblasts.

Figs 53-58. Carpogonial branches in the Polysiphonieae. Four-celled in Polysiphonia stricta (Fig. 53, Polysiphonia sensu stricto clade 1), P. nigra (Fig. 54, Vertebrata clade), $P$. denudata (Fig. 55, Carradoriella clade) and $P$. schneideri (Fig. 56, $P$. schneideri clade). Three-celled in species of the Melanothamnus clade: Neosiphonia harveyi (Fig. 57) and $P$. blandii (Fig. 58). $\mathrm{Su}=$ supporting cell; st = sterile basal cell; 1 4 cells of carpogonial branches. Scale bars: Fig. 53, $30 \mu \mathrm{m}$; Figs 54-58, $20 \mu \mathrm{m}$.

Figs 59-64. Cystocarps in the Polysiphonieae. Urceolate in Polysiphonia stricta (Fig. 59, Polysiphonia sensu stricto clade 1). Ovoid in Vertebrata lanosa (Fig. 60, Vertebrata clade), P. denudata (Fig. 61, Carradoriella clade), Streblocladia glomerulata (Fig. 62, 


\section{3}

Streblocladia clade). Globose in Polysiphonia schneideri (Fig. 63, P. schneideri clade) and Neosiphonia collabens (Fig. 64, Melanothamnus clade). Scale bars: Figs 59-62 and 64, $200 \mu \mathrm{m}$; Fig. 63, $100 \mu \mathrm{m}$.

Figs 65-70. Cells surrounding the ostiole in the Polysiphonieae. Similar or slightly larger than the cells of the pericarp inmediately below in Polysiphonia stricta (Fig. 65, Polysiphonia sensu stricto clade 1), Vertebrata lanosa (Fig. 66, Vertebrata clade), $P$. denudata (Fig. 67, Carradoriella clade), and P. schneideri (Fig. 69, P. schneideri clade). They are much larger in Streblocladia glomerulata (Fig. 68, Streblocladia clade) and Neosiphonia collabens (Fig. 70, Melanothamnus clade). Scale bars: Figs 65-68 and 70, $100 \mu \mathrm{m}$; Fig. $69,60 \mu \mathrm{m}$.

Figs 71-76. Tetrasporangia in the Polysiphonieae. Forming long straight series in Polysiphonia stricta (Fig. 71, Polysiphonia sensu stricto clade 1). Forming spiral series in Vetebrata lanosa (Fig. 72, Vertebrata clade), Polysiphonia sp. (Fig. 74, Streblocladia clade) and Neosiphonia harveyi (Fig. 76, Melanothamnus clade). Forming short straight series in P. denudata (Fig. 73, Carradoriella clade), and P. schneideri (Fig. 75, $P$. schneideri clade). Scale bars: Figs 71, 74 and 76, $200 \mu \mathrm{m}$; Figs 72, 73 and 75, $400 \mu \mathrm{m}$.

Fig. 77. World map representing the proportion of Fernandosiphonia (black) and other Polysiphonieae (grey) species in selected regions where the Polysiphonieae were studied in detail. Data were obtained from the following references after updating the species names: Alaska: Lindstrom (http://www.seaweedsofalaska.com); Brazil (Espírito Santo-São Paulo): Guimâraes et al. (2004); Hawaii: Abbott (1999); Japan: Yoshida 
(1998); Korea: Nam \& Kang (2012); Panama: Mamoozadeh \& Freshwater (2012);

Spain (Galicia): Bárbara et al. (2005); British Isles: Maggs \& Hommersand (1993).

Fig. S1. Chronogram resulting from the Bayesian relaxed molecular clock analysis performed with BEAST.

Fig. S2. Chronogram resulting from the autocorrelated molecular clock analysis performed with PhyloBayes. 


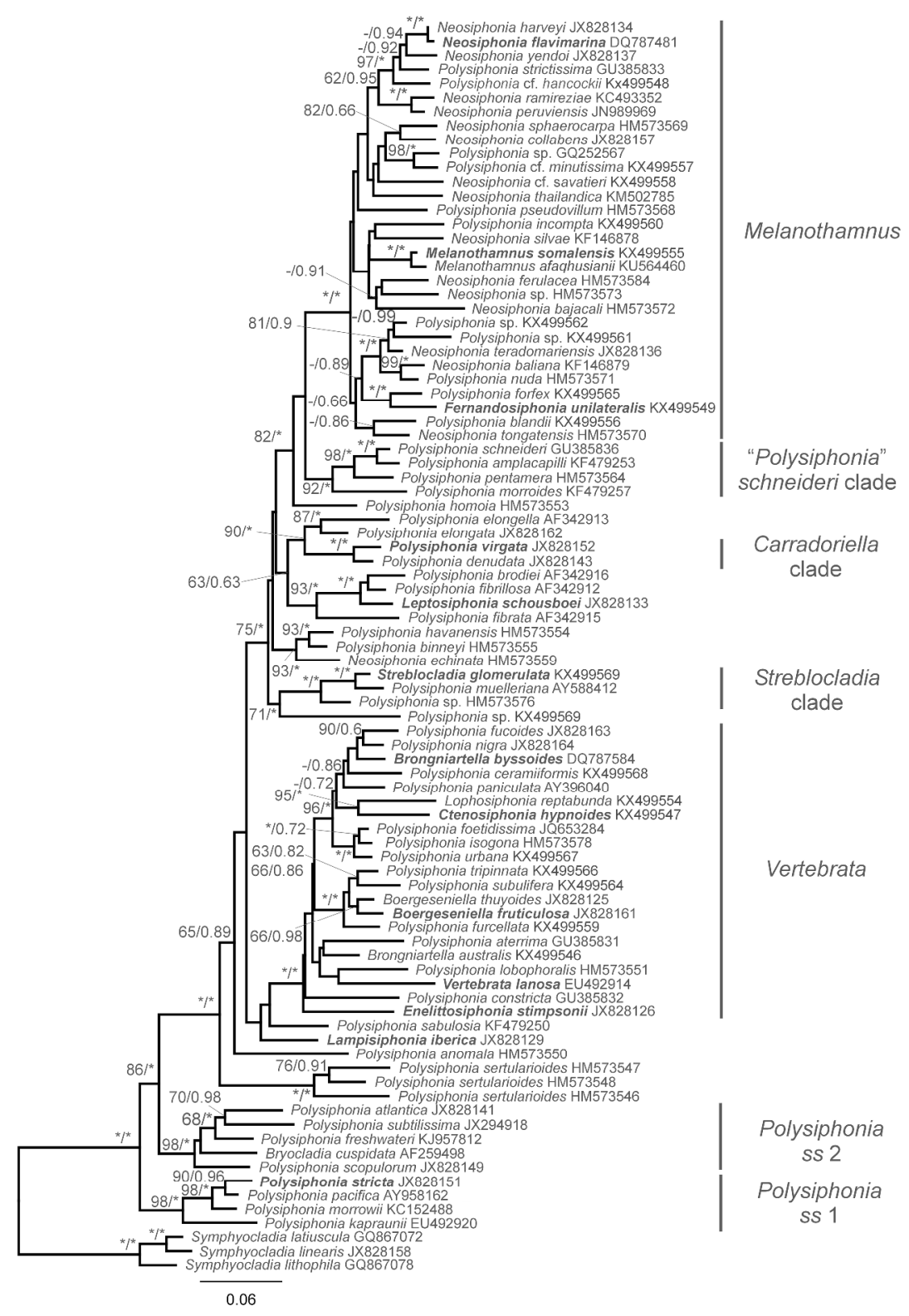

Fig. 1. Phylogenetic tree estimated with $M L$ analysis of $r b c L$ sequences. Values at nodes indicate bootstrap support (BP)/posterior probability (PP) (only shown if $>60 / 0.6$ ). Branches marked with an asterisk received $100 \%(B P) / 1.00$ (PP) support. Species names printed in bold correspond to type species of genera. 
Fig. 2. Phylogenetic tree estimated with ML analysis of $18 \mathrm{~S}$ sequences. Values at nodes indicate bootstrap support/posterior probability (only shown if $>60 \% / 0.6 \mathrm{PP}$ ). Branches marked with an asterisk received $100 \% / 1.00$ PP support. Species names printed in bold correspond to type species of genera. 

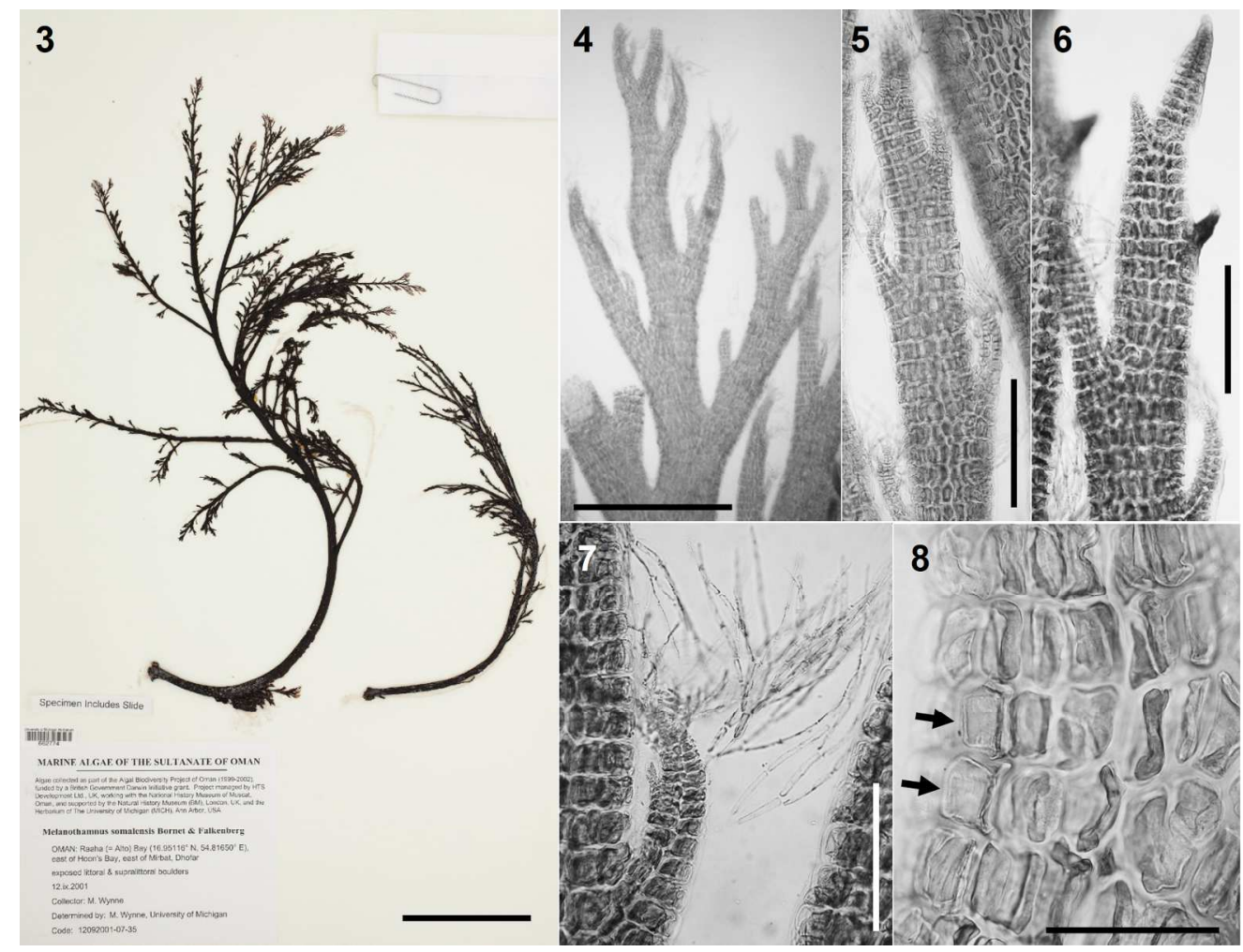

Figs 3-8. Melanothamnus somalensis, the type species of Melanothamnus. Fig. 3. Herbarium specimen MICH 662774. Fig. 4. Apical part of a specimen with alternately arranged branches. Figs 5-6. Apices of branches with (Fig. 5) or without (Fig. 6) abundant trichoblasts. Fig. 7. Apex of a lateral branch with trichoblasts. Fig.

8. Surface view of cells with the plastids lying exclusively on radial walls while the outer walls appear

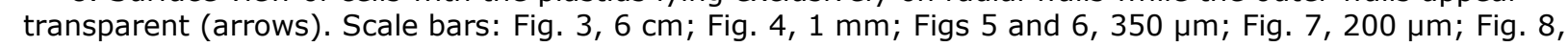
$100 \mu \mathrm{m}$. 

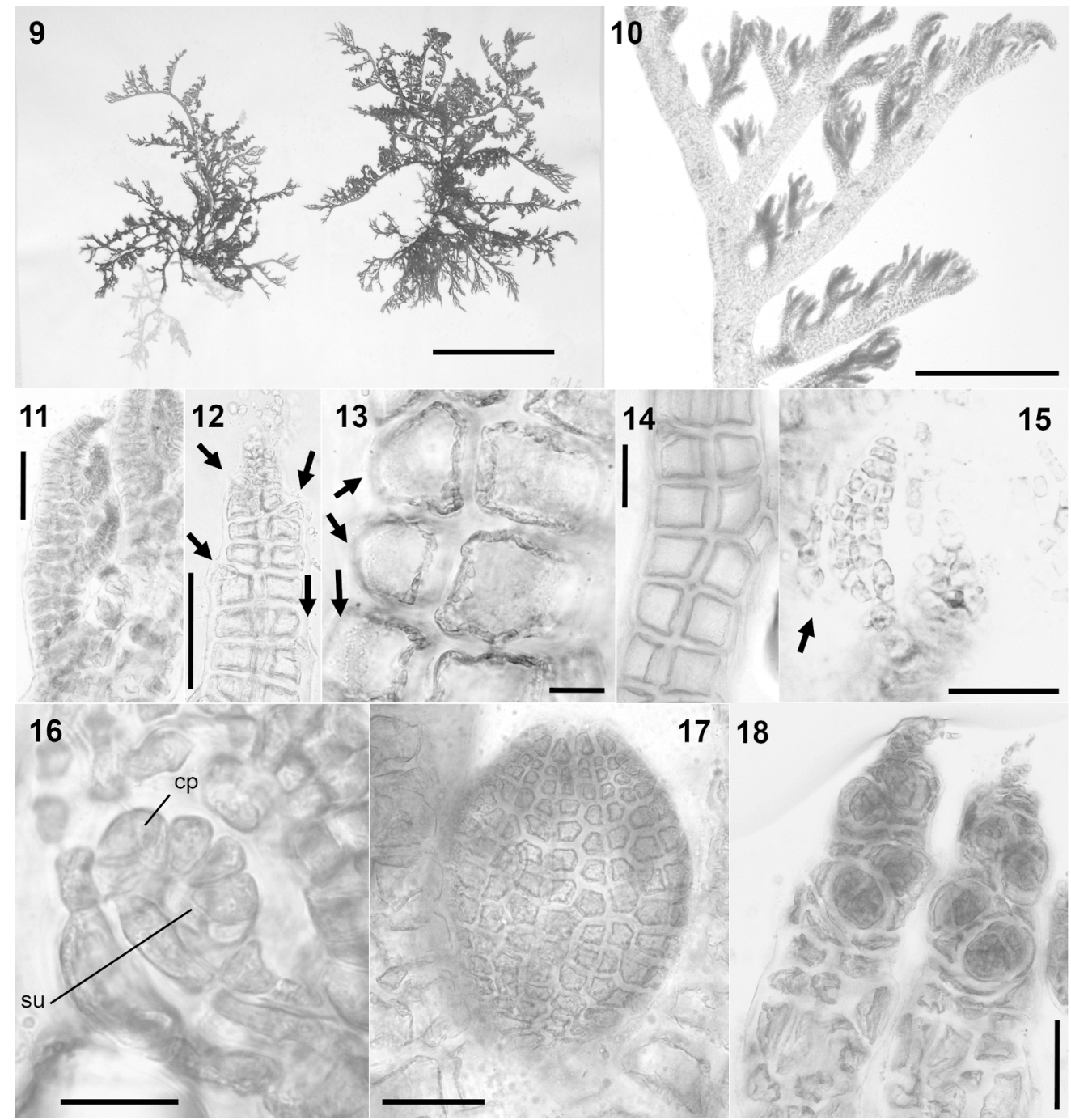

$17 \quad 18$

Figs 9-18. Fernandosiphonia unilateralis type material, the type species of Fernandosiphonia. Fig. 9. Herbarium specimen. Figs 10-11. Branches unilaterally arranged. Fig. 12. Axis with scar cells of trichoblasts (arrows). Figs 13-14. Surface view of pericentral cells with plastids lying only on the radial walls, so that the outer walls appear transparent (Fig. 13, arrows) and cells have a dark flank (Fig. 14). Fig. 15. Young spermatangial branch formed on the first dichotomy of a trichoblast, remaining the other vegetative branch (arrow). Fig. 16. Procarp ( $\mathrm{su}=$ supporting cell; $\mathrm{cp}=$ carpogonium). Fig. 17. Cystocarp. Fig. 18.

Tetrasporangia arranged in short spiral series. Scale bars: Fig. 9, 3 cm; Fig. 10, 2 mm; Fig. 11, $450 \mu \mathrm{m}$; Figs 12, 14, 17 and 18, $100 \mu \mathrm{m}$; Figs 13 and 15, $40 \mu \mathrm{m}$; Fig. 16, $20 \mu \mathrm{m}$. 

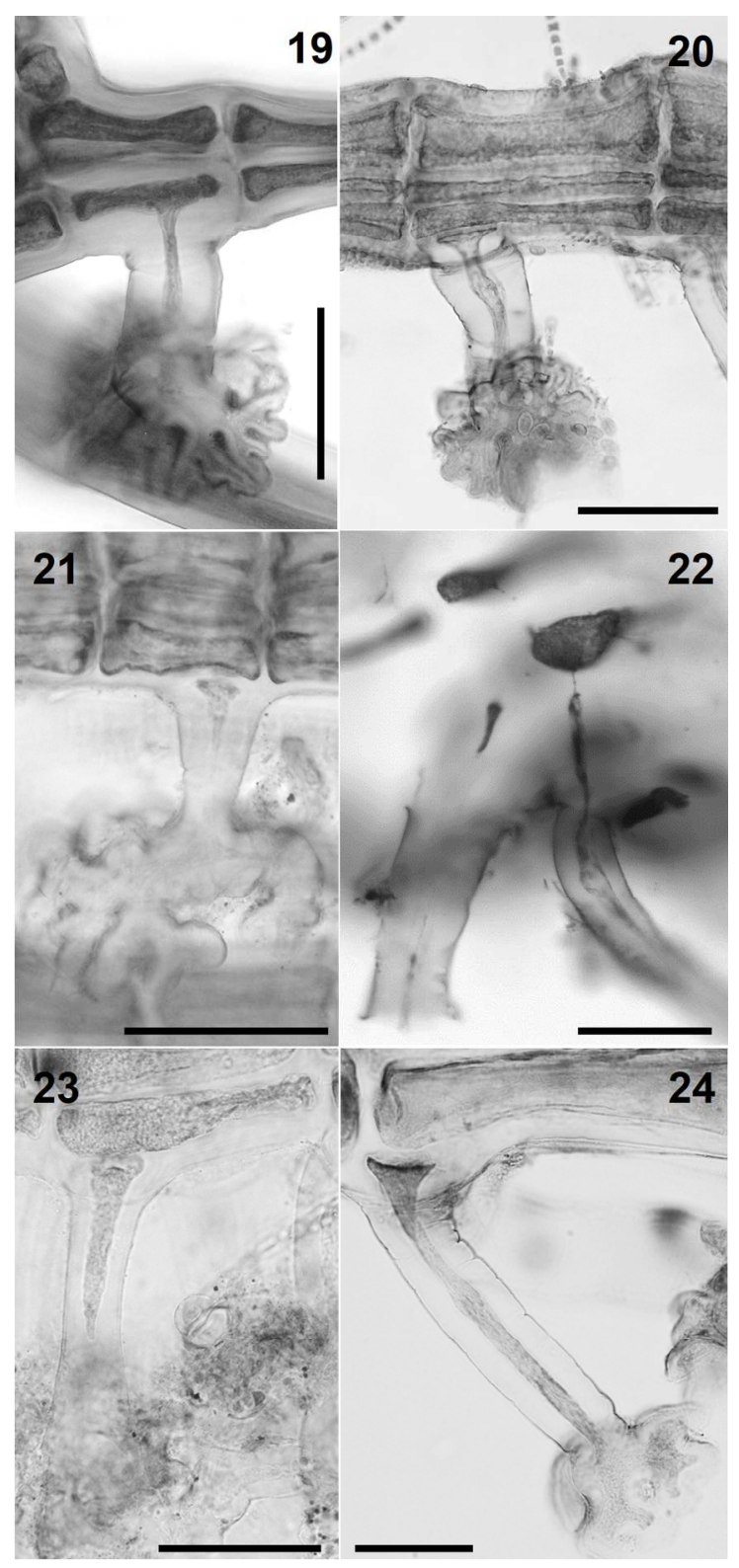

Figs 19-24. Rhizoid anatomy in the Polysiphonieae. In open connection with pericentral cells in Polysiphonia stricta (Fig. 19, Polysiphonia sensu stricto clade 1). Cut off from pericentral cells in P. foetidissima (Fig. 20, Vertebrata clade), P. denudata (Fig. 21, Carradoriella clade), Polysiphonia sp. (Fig. 22, Streblocladia clade), P. schneideri (Fig. 23, P. schneideri clade) and P. incompta (Fig. 24, Melanothamnus clade). Scale bars: Figs 19-23, $100 \mu \mathrm{m}$; Fig. 24, $500 \mu \mathrm{m}$. 


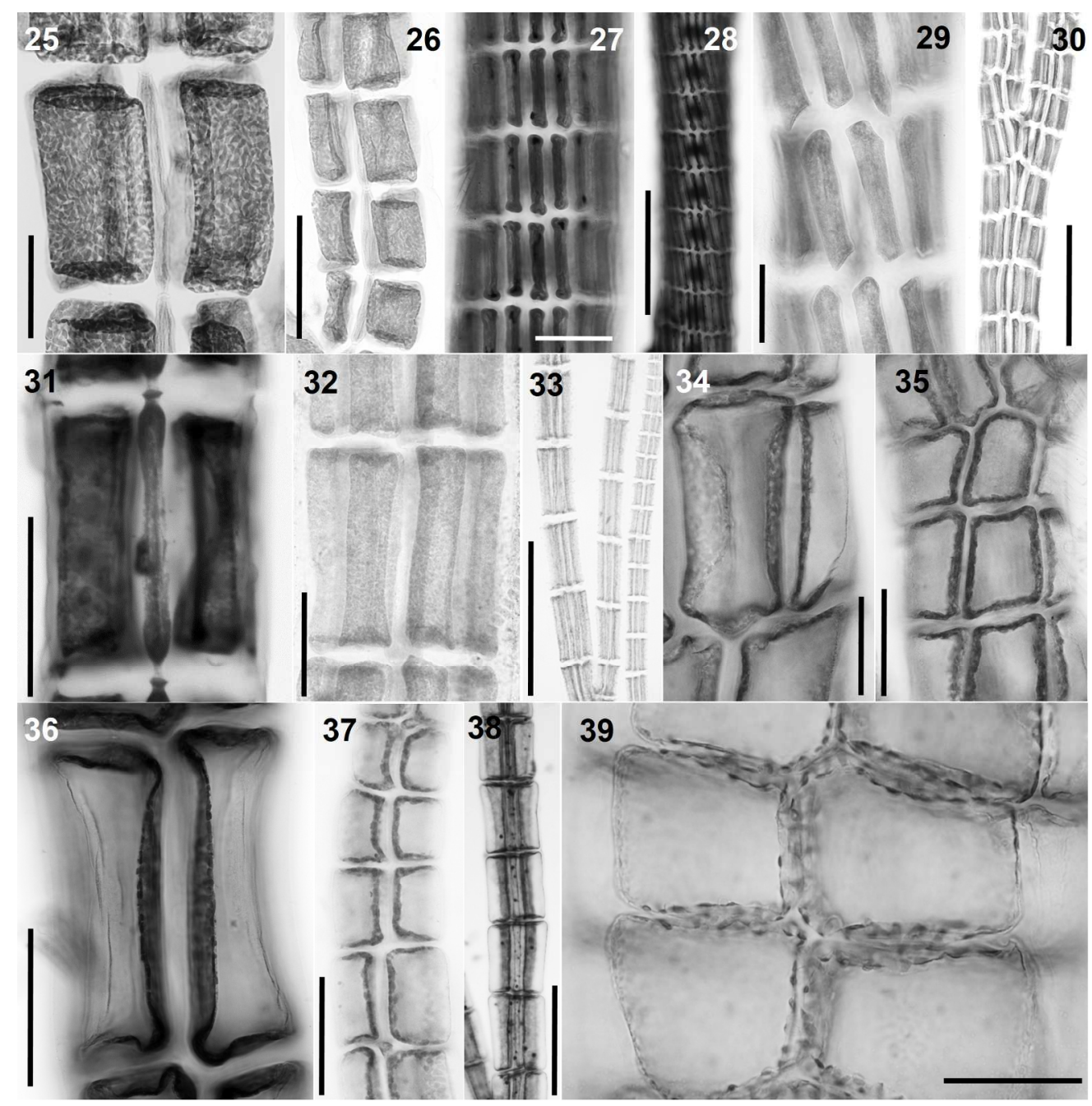

Figs 25-39. Plastid arrangement in the Polysiphonieae. Scattered against all cell walls of the pericentral cells in Polysiphonia stricta (Figs 25-26, Polysiphonia sensu stricto clade 1), Vertebrata lanosa (Figs 27-28, Vertebrata clade), P. virgata (Figs 29-30, Carradoriella clade), Polysiphonia sp. (Fig. 31, Streblocladia clade) and P. schneideri (Figs 32-33, P. schneideri clade). Lying exclusively on the radial walls of the pericentral cells in species of the Melanothamnus clade: Neosiphonia collabens (Figs 34-35), N. harveyi (Figs 36-38) and P. forfex (Fig. 39). Scale bars: Figs 25, 27, 29, 38 and 39, $500 \mu \mathrm{m}$; Figs 26, 28 and 30, $800 \mu \mathrm{m}$; Figs 31, 32, 34, 35 and 37, $100 \mu \mathrm{m}$; Fig. 33, $300 \mu \mathrm{m}$; Fig, 36, $50 \mu \mathrm{m}$. 


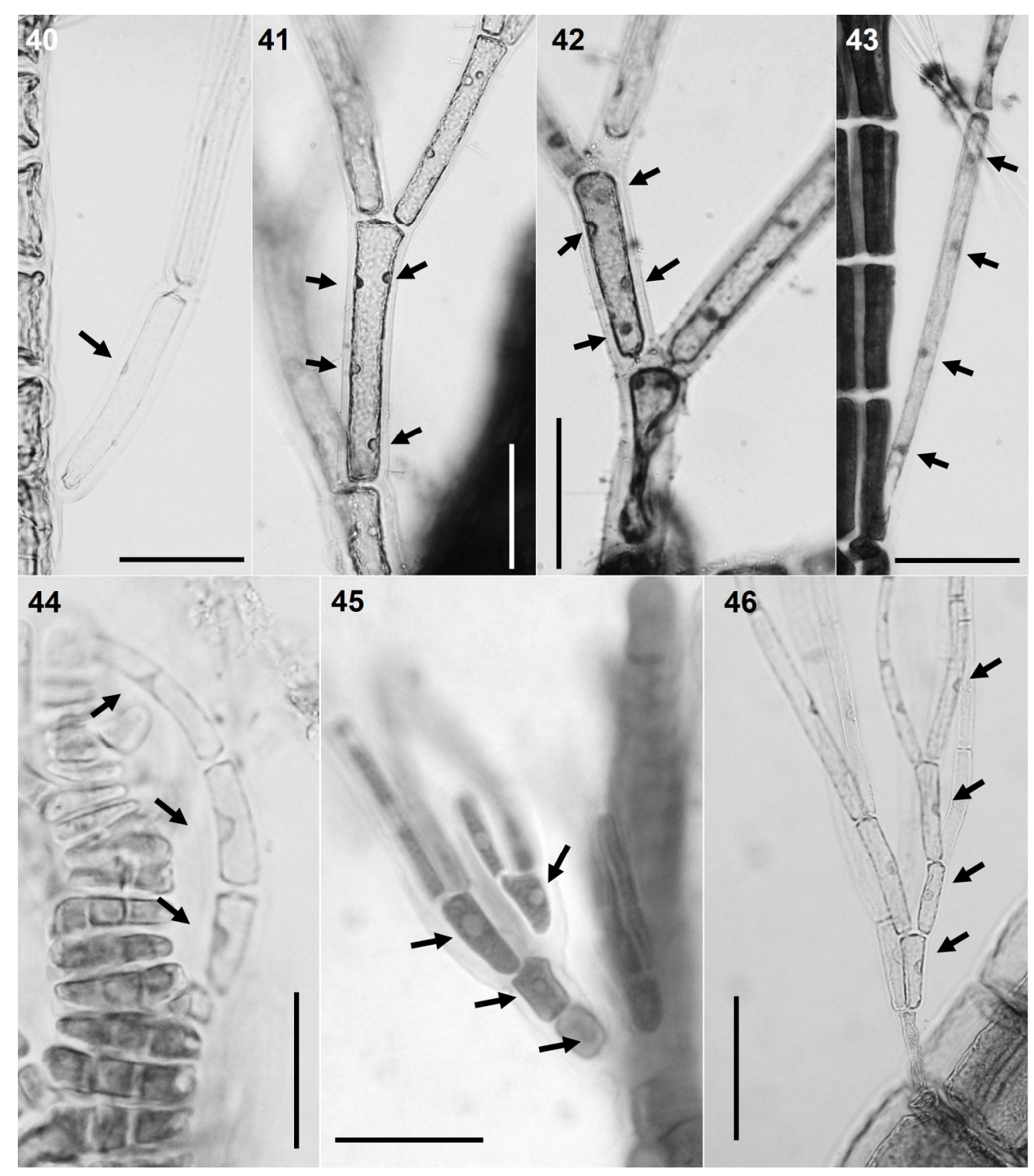

Figs 40-46. Trichoblast nuclei (arrows) in the Polysiphonieae. Uninucleate trichoblast cells in Polysiphonia scopulorum (Fig. 40, Polysiphonia sensu stricto clade 1), P. denudata (Fig. 44, Carradoriella clade), P. schneideri (Fig. 45, P. schneideri clade) and P. blandii (Fig. 46, Melanothamnus clade). Multinucleate trichoblast cells in species of the Vertebrata clade: P. nigra (Fig. 41), Boergeseniella fruticulosa (Fig. 42) and P. foetidissima (Fig. 43). Scale bars: Figs 40-43, $60 \mu \mathrm{m}$, Fig. 44, $30 \mu \mathrm{m}$; Fig. 45, $20 \mu \mathrm{m}$; Fig. $46,100 \mu \mathrm{m}$. 


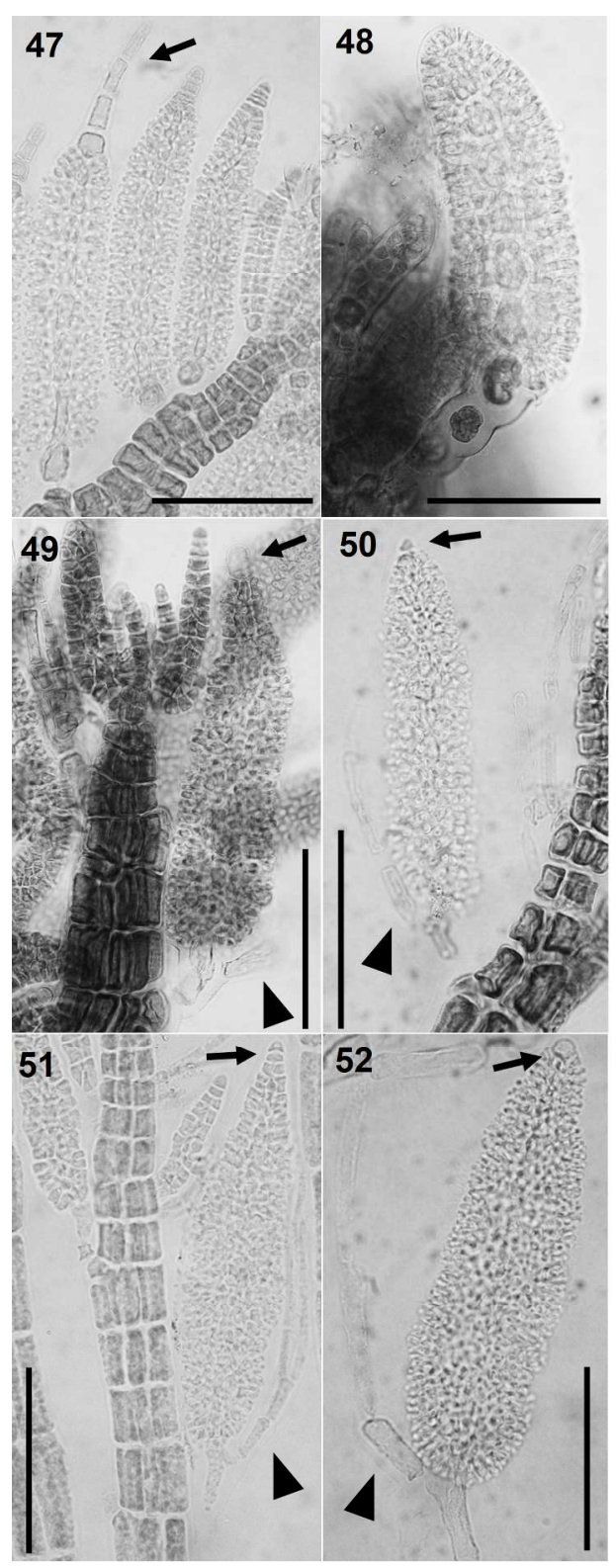

Figs 47-52. Spermatangial branches in the Polysiphonieae. Replacing trichoblasts and with sterile apical filaments in Polysiphonia stricta (Fig. 47, Polysiphonia sensu stricto clade 1). Replacing trichoblasts and lacking sterile apical cells in Vertebrata lanosa (Fig. 48, Vertebrata clade). On a branch of a trichoblast and with sterile apical cells in P. fucoides (Fig. 49, Vertebrata clade), P. denudata (Fig. 50, Carradoriella clade), P. schneideri (Fig. 51, P. schneideri clade) and Neosiphonia harveyi (Fig. 52, Melanothamnus clade). Scale bars: $100 \mu \mathrm{m}$. Arrows show the apical sterile cells and arrowheads the sterile branch of fertile trichoblasts. 


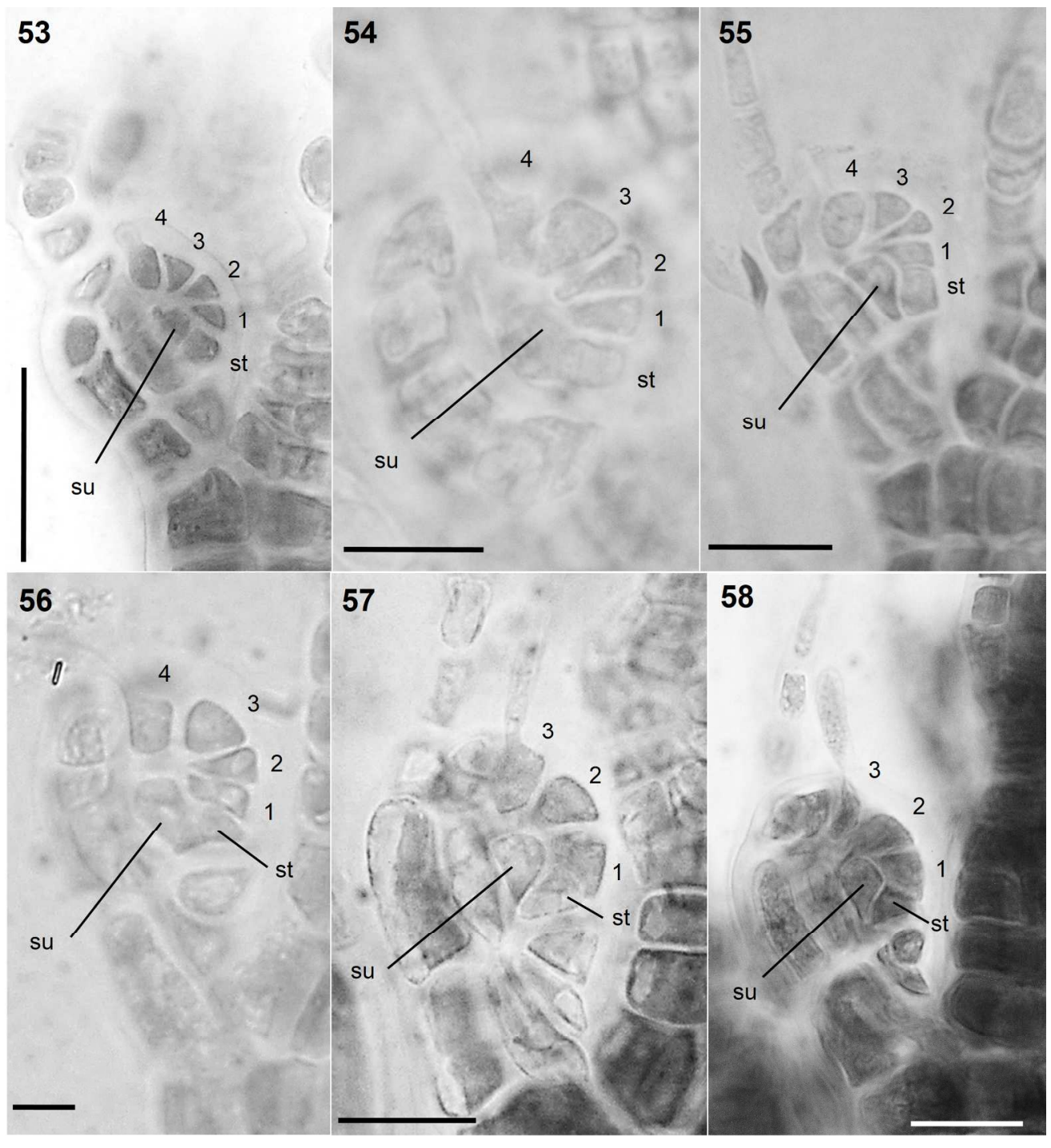

Figs 53-58. Carpogonial branches in the Polysiphonieae. Four-celled in Polysiphonia stricta (Fig. 53, Polysiphonia sensu stricto clade 1), P. nigra (Fig. 54, Vertebrata clade), P. denudata (Fig. 55, Carradoriella clade) and P. schneideri (Fig. 56, P. schneideri clade). Three-celled in species of the Melanothamnus clade: Neosiphonia harveyi (Fig. 57) and P. blandii (Fig. 58). Su = supporting cell; st = sterile basal cell; $1-4$ cells of carpogonial branches. Scale bars: Fig. 53, $30 \mu \mathrm{m}$; Figs 54-58, $20 \mu \mathrm{m}$. 


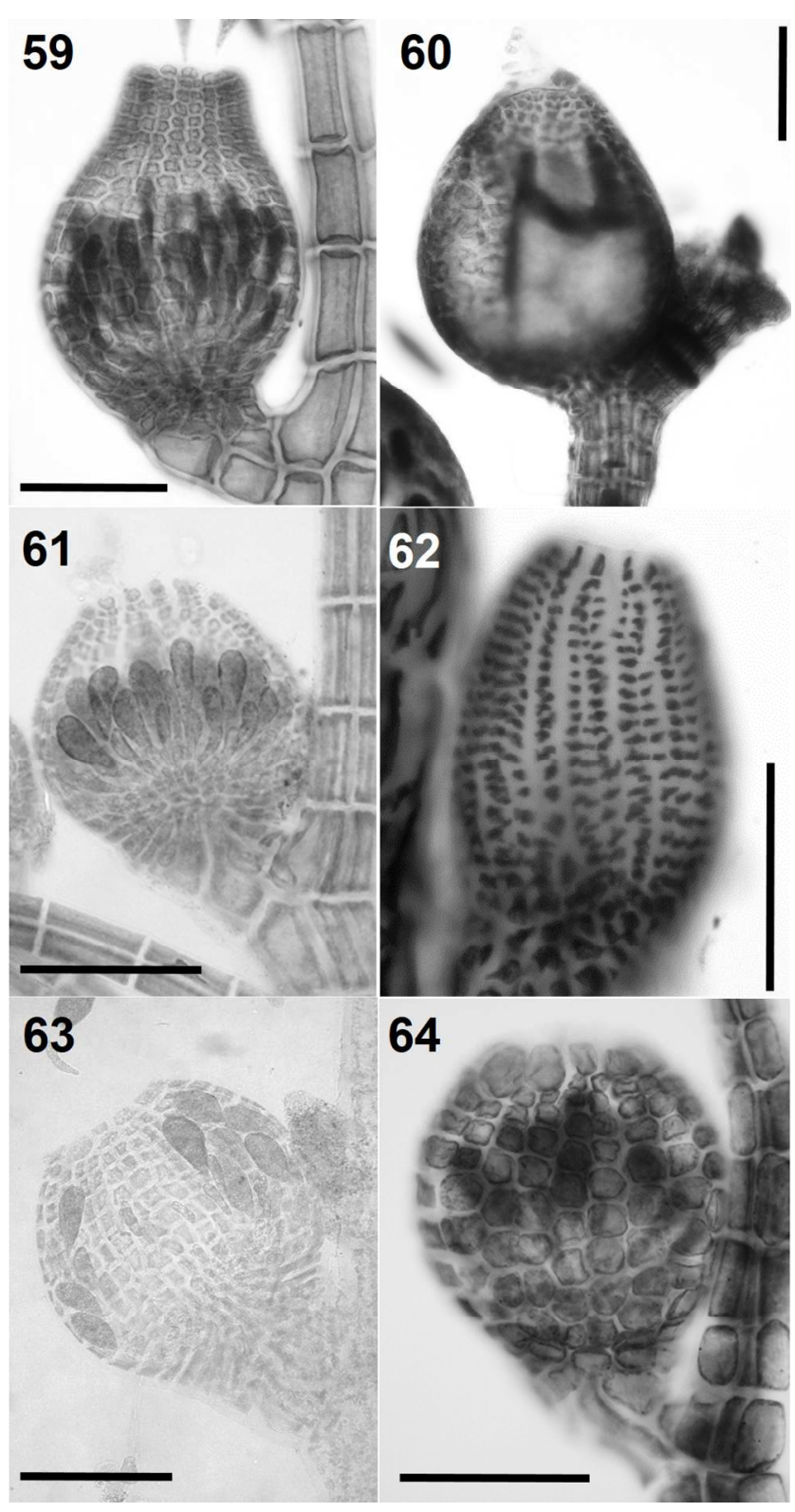

Figs 59-64. Cystocarps in the Polysiphonieae. Urceolate in Polysiphonia stricta (Fig. 59, Polysiphonia sensu stricto clade 1). Ovoid in Vertebrata lanosa (Fig. 60, Vertebrata clade), P. denudata (Fig. 61, Carradoriella clade), Streblocladia glomerulata (Fig. 62, Streblocladia clade). Globose in Polysiphonia schneideri (Fig. 63, P. schneideri clade) and Neosiphonia collabens (Fig. 64, Melanothamnus clade). Scale bars: Figs 59-62 and $64,200 \mu \mathrm{m}$; Fig. 63, $100 \mu \mathrm{m}$. 


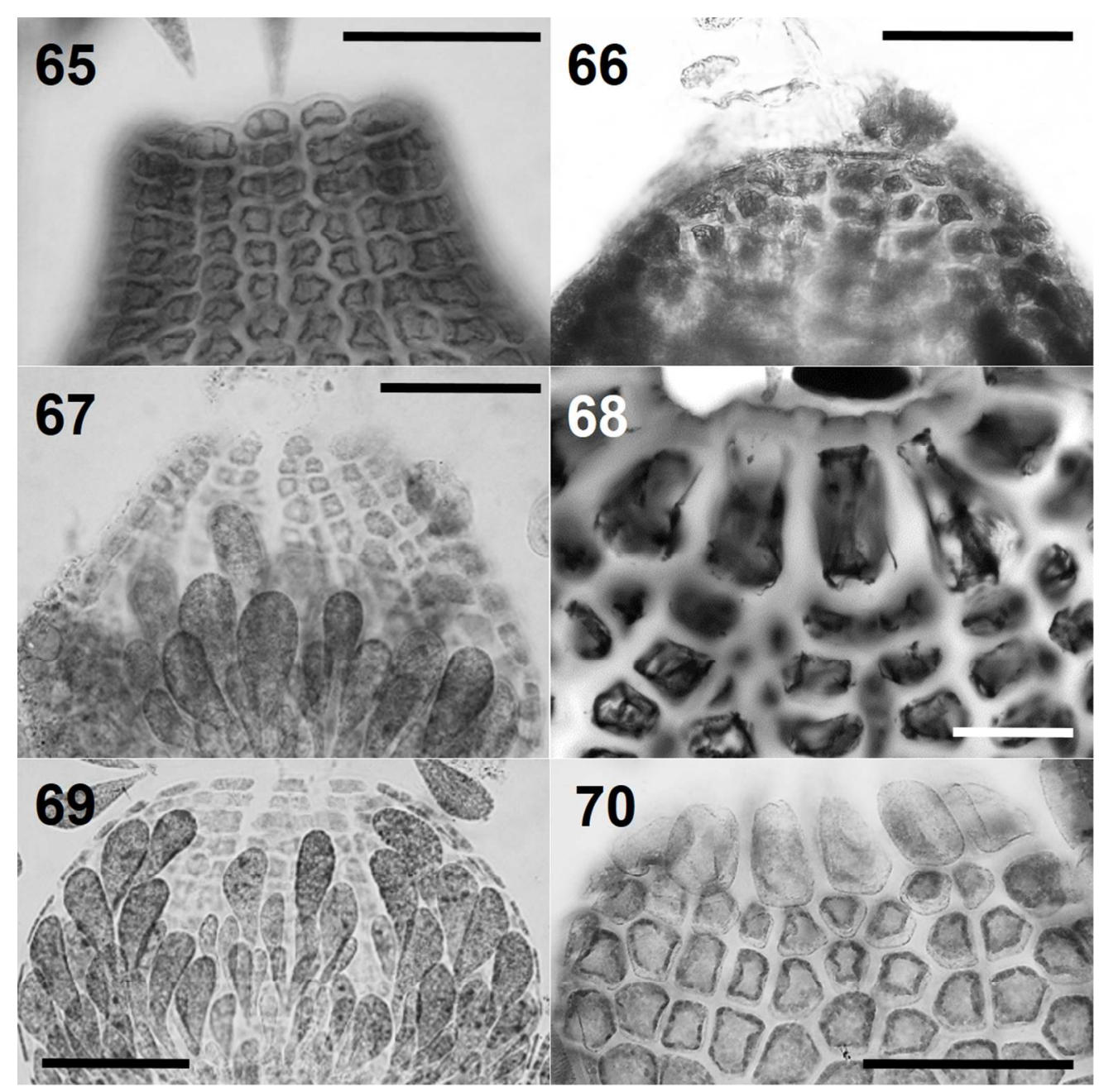

Figs 65-70. Cells surrounding the ostiole in the Polysiphonieae. Similar or slightly larger than the cells of the pericarp inmediately below in Polysiphonia stricta (Fig. 65, Polysiphonia sensu stricto clade 1), Vertebrata lanosa (Fig. 66, Vertebrata clade), P. denudata (Fig. 67, Carradoriella clade), and P. schneideri (Fig. 69, P. schneideri clade). They are much larger in Streblocladia glomerulata (Fig. 68, Streblocladia clade) and Neosiphonia collabens (Fig. 70, Melanothamnus clade). Scale bars: Figs 65-68 and 70, 100 m; Fig. 69,60 $\mu \mathrm{m}$. 


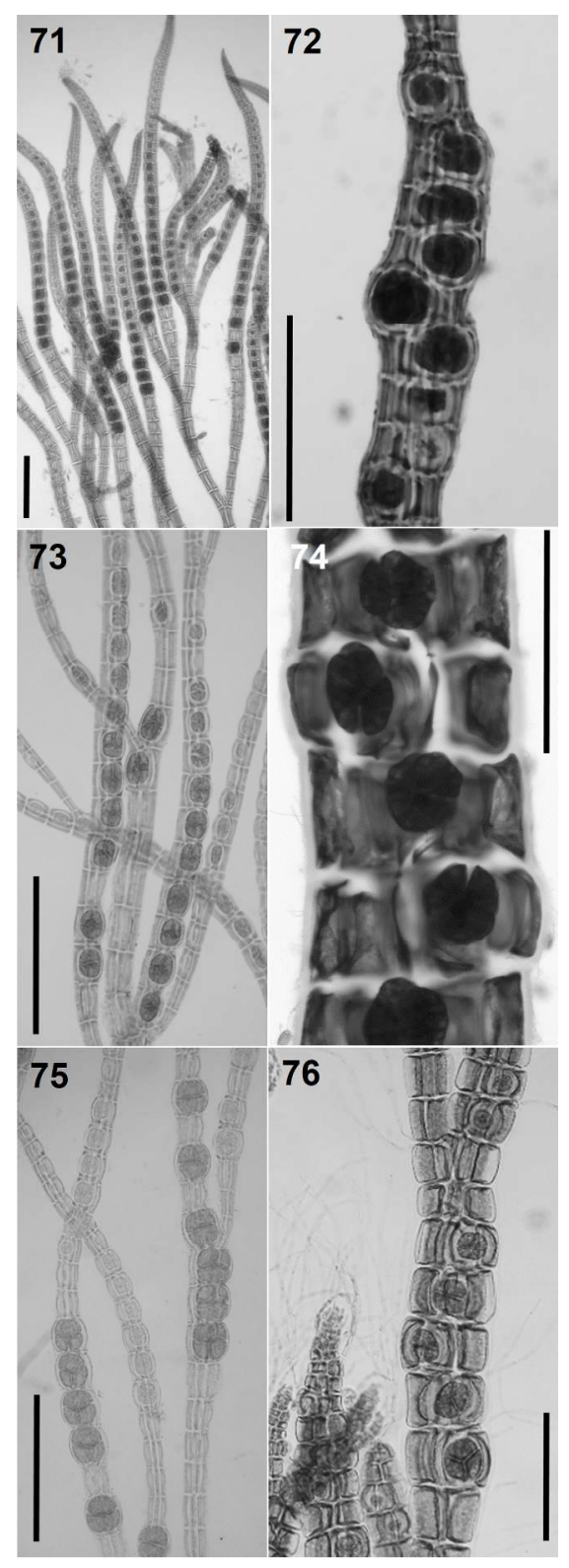

Figs 71-76. Tetrasporangia in the Polysiphonieae. Forming long straight series in Polysiphonia stricta (Fig. 71, Polysiphonia sensu stricto clade 1). Forming spiral series in Vetebrata lanosa (Fig. 72, Vertebrata clade), Polysiphonia sp. (Fig. 74, Streblocladia clade) and Neosiphonia harveyi (Fig. 76, Melanothamnus clade). Forming short straight series in P. denudata (Fig. 73, Carradoriella clade), and P. schneideri (Fig. 75, P. schneideri clade). Scale bars: Figs 71, 74 and 76, $200 \mu \mathrm{m}$; Figs 72, 73 and 75, $400 \mu \mathrm{m}$. 
Fig. 77. World map representing the proportion of Fernandosiphonia (black) and other Polysiphonieae (grey) species in selected regions where the Polysiphonieae were studied in detail. Data were obtained from the following references after updating the species names: Alaska: Lindstrom

(http://www.seaweedsofalaska.com); Brazil (Espírito Santo-São Paulo): Guimâraes et al. (2004); Hawaii: Abbott (1999); Japan: Yoshida (1998); Korea: Nam \& Kang (2012); Panama: Mamoozadeh \& Freshwater (2012); Spain (Galicia): Bárbara et al. (2005); British Isles: Maggs \& Hommersand (1993). 
Table S1. Sample information for the species included in the phylogenetic analysis.

\begin{tabular}{|c|c|c|c|}
\hline \multirow[t]{2}{*}{ Species (current name) } & \multirow{2}{*}{$\begin{array}{l}\text { Publication or collection data and } \\
\text { herbarium voucher for new sequences }\end{array}$} & \multicolumn{2}{|c|}{ GenBank accession number } \\
\hline & & $r b c \mathrm{~L}$ & SSU \\
\hline Boergeseniella fruticulosa (Wulfen) Kylin & Bárbara et al. (2013) / Choi et al. (2001) & JX828161 & AF427526 \\
\hline Boergeseniella thuyoides (Harvey) Kylin & Bárbara et al. (2013) & JX828125 & JX828165 \\
\hline Brongniartella australis (C.Agardh) F.Schmitz & $\begin{array}{l}\text { Pope's Eye, Port Phillip Bay, Victoria } \\
\text { Australia, 1.xii.2014, P. Díaz-Tapia \& V. } \\
\text { Marcelino; MEL }\end{array}$ & KX499546 & KX499570 \\
\hline Brongniartella byssoides (Goodenough \& Woodward) F.Schmitz & $\begin{array}{l}\text { Yang et al. (2016) / Fanan Head, Donegal, } \\
\text { Ireland, 15.vi.2015, P. Díaz-Tapia \& C. } \\
\text { Maggs; SANT } 31111\end{array}$ & DQ787584 & KX499571 \\
\hline Bryocladia cuspidata (J.Agardh) De Toni & Lin et al. (2001) & AF259498 & - \\
\hline
\end{tabular}




\begin{tabular}{|c|c|c|c|}
\hline Ctenosiphonia hypnoides (Welwitsch ex J.Agardh) Falkenberg & $\begin{array}{l}\text { Ensenada Cegoñas, Lugo, Spain, } \\
\text { 15.vii.2010, P. Díaz-Tapia \& I. Bárbara; } \\
\text { SANT } 24410\end{array}$ & KX499547 & - \\
\hline Enelittosiphonia stimpsonii (Harvey) Kudo \& Masuda & Bárbara et al. (2013) / Choi et al. (2001) & JX828126 & AF427527 \\
\hline Fernandosiphonia unilateralis Levring & $\begin{array}{l}\text { Juan Fernández, Chile, E. Macayo; SANT } \\
\text { 31104-6 }\end{array}$ & KX499549-52 & KX499572-3 \\
\hline Fernandosiphonia unilateralis Levring & Type material, GB & KX499553 & - \\
\hline Herposiphonia parca Setchell & Bárbara et al. (2013) & - & JX828166 \\
\hline Lampisiphonia iberica Bárbara, Secilla, Díaz \& H.-G. Choi & Bárbara et al. (2013) & JX828129 & JX828168 \\
\hline Leptosiphonia schousboei (Thuret) Kylin & Bárbara et al. (2013) & JX828133 & JX828170 \\
\hline Lophosiphonia reptabunda (Suhr) Kylin & $\begin{array}{l}\text { Zumaia, Basque Country, Spain, } \\
\text { 18.iii.2011, P. Díaz-Tapia \& I. Bárbara; }\end{array}$ & KX499554 & KX499574 \\
\hline
\end{tabular}




\begin{tabular}{|c|c|c|c|}
\hline & SANT 25139 & & \\
\hline Melanothamnus somalensis Bornet \& Falkenberg & $\begin{array}{l}\text { Raaha Bay, Oman, 12.ix.2001, M. Wynne; } \\
\text { MICH } 662274\end{array}$ & KX499555 & - \\
\hline Melanothamnus afaqhusainii Bornet \& Falkenberg & $\begin{array}{l}\text { Savoie \& Saunders (2016, as } M \text {. } \\
\text { somalensis) }\end{array}$ & KU564460 & - \\
\hline N. teradomariensis (M. Noda) M.S. Kim \& I.K. Lee & Bárbara et al. (2013) & JX828136 & JX828174 \\
\hline $\begin{array}{l}\text { Neosiphonia bajacali (Hollenberg) N.R.Mamoozadeh \& } \\
\text { D.W.Freshwater }\end{array}$ & Mamoozadeh \& Freshwater (2011) & HM573572 & HM560659 \\
\hline Neosiphonia baliana D.E.Bustamante, B.Y.Won \& T.O.Cho & Bustamante et al. (2013) & KF146879 & - \\
\hline Neosiphonia collabens (C. Agardh) Díaz-Tapia \& Bárbara & $\begin{array}{l}\text { Bárbara et al. (2013, as Streblocladia } \\
\text { collabens) }\end{array}$ & JX828157 & JX828188 \\
\hline Neosiphonia echinata (Harvey) N.Mamoozadeh \& D.W.Freshwater & Mamoozadeh \& Freshwater (2011) & HM573559 & HM560658 \\
\hline
\end{tabular}




\begin{tabular}{|c|c|c|c|}
\hline $\begin{array}{l}\text { Neosiphonia ferulacea (Suhr ex J.Agardh) S.M.Guimarães \& } \\
\text { M.T.Fujii }\end{array}$ & Mamoozadeh \& Freshwater (2011) & HM573584 & - \\
\hline Neosiphonia flavimarina M.-S.Kim \& I.K.Lee & Kim \& Yang (2006) & DQ787481 & - \\
\hline $\begin{array}{l}\text { Neosiphonia harveyi (J. Bailey) M.-S. Kim, H.-G. Choi, M.D. } \\
\text { Guiry \& G.W. Saunders }\end{array}$ & Bárbara et al. (2013) & JX828134 & JX828172 \\
\hline $\begin{array}{l}\text { Neosiphonia peruviensis D.E.Bustamante, B.Y.Won, M.E.Ramirez } \\
\text { \& T.O.Cho }\end{array}$ & Bustamante et al. (2012b) & JN989969 & - \\
\hline Neosiphonia cf. savatieri (Hariot) M.S.Kim \& I.K.Lee & $\begin{array}{l}\text { Onno, Okinawa, Japan, 10.xi.2003, C. } \\
\text { Trowbridge; BM }\end{array}$ & KX499558 & \\
\hline Neosiphonia silvae D.E.Bustamante, B.Y.Won \& T.O.Cho & Bustamante et al. (2013) & KF146878 & - \\
\hline Neosiphonia ramireziae D.E.Bustamante, B.Y.Won \& T.O.Cho & Bustamante et al. (2012a) & KC493352 & - \\
\hline Neosiphonia sp. & Mamoozadeh \& Freshwater (2011) & HM573573 & HM560649 \\
\hline
\end{tabular}




\begin{tabular}{|c|c|c|c|}
\hline Neosiphonia sphaerocarpa (Børgesen) M.-S.Kim \& I.K.Lee & Mamoozadeh \& Freshwater (2011) & HM573569 & - \\
\hline Neosiphonia thailandica N.Muangmai \& C.Kaewsuralikhit & Muangmai et al. (2014) & KM502785 & - \\
\hline Neosiphonia tongatensis (Harvey ex Kützing) M.-S.Kim \& I.K.Lee & Mamoozadeh \& Freshwater (2011) & HM573570 & HM560642 \\
\hline Neosiphonia yendoi (Segi) M.S. Kim \& I.K. Lee & Bárbara et al. (2013) & JX828137 & JX828175 \\
\hline Polysiphonia amplacapilli B.Kim \& M.S.Kim & Kim \& Kim (2014) & KF479253 & - \\
\hline Polysiphonia anomala Hollenberg & Mamoozadeh \& Freshwater (2011) & HM573550 & - \\
\hline Polysiphonia aterrima J.D.Hooker \& Harvey & $\begin{array}{l}\text { Stuercke \& Freshwater (2010) / } \\
\text { Mamoozadeh \& Freshwater (2011) }\end{array}$ & GU385831 & HM560638 \\
\hline Polysiphonia atlantica Kapraun \& J.N. Norris & Bárbara et al. (2013) & JX828141 & JX828179 \\
\hline Polysiphonia atlantica Kapraun \& J.N. Norris & $\begin{array}{l}\text { Stuercke \& Freshwater (2008) / } \\
\text { Mamoozadeh \& Freshwater (2011) }\end{array}$ & - & HM560631 \\
\hline Polysiphonia binneyi Harvey & Mamoozadeh \& Freshwater (2011) & HM573555 & HM560636 \\
\hline
\end{tabular}




\begin{tabular}{|c|c|c|c|}
\hline Polysiphonia blandii Harvey & $\begin{array}{l}\text { Sandrigham, Port Phillip Bay, Victoria } \\
\text { Australia, 8.i.2015, P. Díaz-Tapia \& } \\
\text { M.Brookes; SANT } 31107\end{array}$ & KX499556 & - \\
\hline Polysiphonia brodiei (Dillwyn) Sprengel & McIvor et al. (2001) / Bárbara et al. (2013) & AF342916 & JX828192 \\
\hline Polysiphonia ceramiiformis P.Crouan \& H.Crouan & $\begin{array}{l}\text { Wembury Point, Exeter, England, UK, } \\
\text { 23.iii.2016, P. Díaz-Tapia \& C. Maggs; } \\
\text { SANT } 31108\end{array}$ & KX499568 & KX499575 \\
\hline Polysiphonia constricta Womersley & $\begin{array}{l}\text { Stuercke \& Freshwater (2010) / } \\
\text { Mamoozadeh \& Freshwater (2011) }\end{array}$ & GU385832 & HM560639 \\
\hline Polysiphonia denudata (Dillwyn) Grevill ex Harvey & Bárbara et al. (2013) & JX828143 & JX828182 \\
\hline Polysiphonia elongata (Hudson) Sprengel & Bárbara et al. (2013) / Choi et al. (2001) & JX828162 & AF427529 \\
\hline Polysiphonia elongella Harvey & McIvor et al. (2001) & AF342913 & - \\
\hline
\end{tabular}




\begin{tabular}{|c|c|c|c|}
\hline Polysiphonia fibrata (Dillwyn) Harvey & $\begin{array}{l}\text { McIvor et al. (2001) / Kimmeridge, } \\
\text { Dorset, England, UK, 6.vi.2015, P. Díaz- } \\
\text { Tapia \& C. Maggs; SANT } 31110\end{array}$ & AF342915 & KX499576 \\
\hline Polysiphonia fibrillosa (Dillwyn) Sprengel & $\begin{array}{l}\text { McIvor et al. (2001) / Swangea, Dorset, } \\
\text { England, UK, 7.vi.2015, P. Díaz-Tapia \& } \\
\text { C. Maggs; SANT } 31110\end{array}$ & AF342912 & KX499577 \\
\hline Polysiphonia foetidissima Cocks ex Bornet & Díaz-Tapia et al. (2013) & JQ653284 & - \\
\hline Polysiphonia forfex Harvey & $\begin{array}{l}\text { Rottnest Island, Western Australia, } \\
\text { 15.iii.2015, P. Díaz-Tapia \& J. Costa; } \\
\text { MEL }\end{array}$ & KX499565 & - \\
\hline Polysiphonia freshwateri D.Bustamante, B.Y.Won \& T.O.Cho & Bustamante et al. (2015) & KJ957812 & - \\
\hline Polysiphonia fucoides (Hudson) Sprengel & $\begin{array}{l}\text { Bárbara et al. (2013) / Mamoozadeh \& } \\
\text { Freshwater (2011) }\end{array}$ & JX828163 & HM560627 \\
\hline
\end{tabular}




\begin{tabular}{|c|c|c|c|}
\hline Polysiphonia furcellata (C.Agardh) Harvey & $\begin{array}{l}\text { Pwllheli, Wales, UK, 20.viii.1998, C. } \\
\text { Maggs; BM }\end{array}$ & KX499559 & - \\
\hline Polysiphonia cf. hancockii (Dawson) R.E.Norris & $\begin{array}{l}\text { Makung, Taiwan, v.2002, M. } \\
\text { Hommersand \& S.-M. Lin; BM }\end{array}$ & KX499548 & - \\
\hline Polysiphonia havanensis Montagne & Mamoozadeh \& Freshwater (2011) & HM573554 & HM560641 \\
\hline Polysiphonia homoia Setchell \& N.L.Gardner & Mamoozadeh \& Freshwater (2011) & HM573553 & HM560653 \\
\hline Polysiphonia incompta Harvey & $\begin{array}{l}\text { Preekstoel, Western Cape, South Africa, } \\
\text { 25.xi.2014, K. Dixon \& J. Ferreira; MEL }\end{array}$ & KX499560 & - \\
\hline Polysiphonia isogona Harvey & $\begin{array}{l}\text { Mamoozadeh \& Freshwater (2011) / } \\
\text { Frankston, Dave's Bay, Port Phillip Bay, } \\
\text { Victoria, Australia, 19.xi.2014, H. } \\
\text { Verbruggen, MEL }\end{array}$ & HM573578 & KX499578 \\
\hline Polysiphonia kapraunii B.Stuercke \& D.W.Freshwater & Stuercke \& Freshwater (2008) / & EU492920 & HM560630 \\
\hline
\end{tabular}




\begin{tabular}{|c|c|c|c|}
\hline & Mamoozadeh \& Freshwater (2011) & & \\
\hline Polysiphonia lobophoralis N.R.Mamoozadeh \& D.W.Freshwater & Mamoozadeh \& Freshwater (2011) & HM573551 & HM560657 \\
\hline Polysiphonia macrocarpa (C.Agardh) Sprengel & Mamoozadeh \& Freshwater (2011) & - & HM560632 \\
\hline Polysiphonia cf. minutissima Hollenberg & $\begin{array}{l}\text { Sunabe, Okinawa, Japan, 6.xi.2003, C. } \\
\text { Towbridge; BM }\end{array}$ & KX499557 & - \\
\hline Polysiphonia morroides B.Kim \& M.S.Kim & Kim \& Kim (2014) & KF479257 & - \\
\hline Polysiphonia morrowii Harvey & $\begin{array}{l}\text { D’ Archino et al. (2013) / Choi et al. } \\
\text { (2001) }\end{array}$ & KC152488 & AF427532 \\
\hline Polysiphonia muelleriana J.Agardh & Fujii et al. (2006) & AY588412 & - \\
\hline Polysiphonia nigra (Hudson) Batters & Bárbara et al. (2013) / Choi et al. (2001) & JX828164 & AF427534 \\
\hline Polysiphonia nuda N.R.Mamoozadeh \& D.W.Freshwater & Mamoozadeh \& Freshwater (2011) & HM573571 & HM560648 \\
\hline Polysiphonia pacifica Hollenberg & Kim et al. (2004) / Choi et al. (2001) & AY958162 & AF427533 \\
\hline
\end{tabular}




\begin{tabular}{|c|c|c|c|}
\hline Polysiphonia paniculata Montagne & Kim et al. (2004) from Chile & AY396040 & - \\
\hline Polysiphonia paniculata Montagne & Zuccarello et al. (2004) from California & - & AY617144 \\
\hline Polysiphonia pentamera Hollenberg & Mamoozadeh \& Freshwater (2011) & HM573564 & HM560643 \\
\hline Polysiphonia pseudovillum Hollenberg & Mamoozadeh \& Freshwater (2011) & HM573568 & HM560650 \\
\hline Polysiphonia sabulosia B.Kim \& M.S.Kim & Kim \& Kim (2014) & KF479250 & - \\
\hline Polysiphonia schneideri B.Stuercke \& D.W.Freshwater & $\begin{array}{l}\text { Stuercke \& Freshwater (2010) / } \\
\text { Mamoozadeh \& Freshwater (2011) }\end{array}$ & GU385836 & HM560629 \\
\hline Polysiphonia scopulorum Harvey & Bárbara et al. (2013) & JX828149 & JX828184 \\
\hline Polysiphonia scopulorum var. villum (J.Agardh) Hollenberg & Mamoozadeh \& Freshwater (2011) & - & HM560633 \\
\hline Polysiphonia sertularioides (Grateloup) J.Agardh FL1 & Mamoozadeh \& Freshwater (2011) & HM573548 & HM560646 \\
\hline Polysiphonia sertularioides (Grateloup) J.Agardh FL2 & Mamoozadeh \& Freshwater (2011) & HM573547 & HM560652 \\
\hline Polysiphonia sertularioides (Grateloup) J.Agardh FL3 & Mamoozadeh \& Freshwater (2011) & HM573546 & HM560647 \\
\hline
\end{tabular}




\begin{tabular}{|c|c|c|c|}
\hline Polysiphonia sp. & Carlile (2009) & GQ252567 & - \\
\hline Polysiphonia sp. & $\begin{array}{l}\text { Sunabe, Okinawa, Japan, 9.iii.2003, C. } \\
\text { Trowbridge; BM }\end{array}$ & KX499561 & - \\
\hline Polysiphonia sp. & $\begin{array}{l}\text { Sail Rock, Taiwan, v.2002, M.H. } \\
\text { Hommersand; BM }\end{array}$ & KX499562 & - \\
\hline Polysiphonia sp. Womersley & $\begin{array}{l}\text { Mamoozadeh \& Freshwater (2011, as } P \text {. } \\
\text { pernacola) }\end{array}$ & HM573576 & HM560637 \\
\hline Polysiphonia sp. & New Zealand, W. Freshwater, WNC 34062 & KX499569 & - \\
\hline Polysiphonia stricta (Dillwyn) Greville & Bárbara et al. (2013) / Choi et al. (2001) & JX828151 & AF427535 \\
\hline Polysiphonia strictissima J.D.Hooker \& Harvey & $\begin{array}{l}\text { Stuercke \& Freshwater (2010) / } \\
\text { Mamoozadeh \& Freshwater (2011) }\end{array}$ & GU385833 & - \\
\hline Polysiphonia subtilissima Montagne & Lam et al. (2013) / Mamoozadeh \& & JX294918 & HM560634 \\
\hline
\end{tabular}




\begin{tabular}{|c|c|c|c|}
\hline & Freshwater (2011) & & \\
\hline Polysiphonia subulifera (C.Agardh) Harvey & $\begin{array}{l}\text { Kingstown Bay, Co. Galway, Ireland, } \\
\text { 22.ix.1999, C. Maggs; BM }\end{array}$ & KX499564 & - \\
\hline Polysiphonia tripinnata J.Agardh & $\begin{array}{l}\text { Peinzás, Lugo, Spain, 18.ix.2008, P. Díaz- } \\
\text { Tapia \& I. Bárbara; SANT } 22246\end{array}$ & KX499566 & - \\
\hline Polysiphonia urbana Harvey & $\begin{array}{l}\text { Shelley Beach, Eastern Cape, South } \\
\text { Africa, 8.xii.2014, K. Dixon \& J. Ferreira; } \\
\text { MEL }\end{array}$ & KX499567 & - \\
\hline Polysiphonia virgata (C. Agardh) Sprengel & Bárbara et al. (2013) & JX828152 & JX828185 \\
\hline Xiphosiphonia pennata (C. Agardh) Savoie \& Saunders & Bárbara et al. (2013) & - & JX828187 \\
\hline Streblocladia glomerulata (Montagne) Papenfuss & $\begin{array}{l}\text { New Zealand, W. Freshwater; WNC } \\
34061\end{array}$ & KX499569 & KX499579 \\
\hline
\end{tabular}




\begin{tabular}{|l|l|c|}
\hline Symphyocladia latiuscula (Harvey) Yamada & Kim et al. (2010) & GQ867072 \\
\hline Symphyocladia linearis (Okamura) Falkenberg & Bárbara et al. (2013) & JX828158 \\
\hline Symphyocladia lithophila M.-S.Kim & Kim et al. (2010) & GQ867078 \\
\hline Vertebrata lanosa (Linneaeus) T. Christensen & Stuercke \& Freshwater (2008) / Phillips et & EU492914 \\
& al. (2000) & AF203886 \\
\hline
\end{tabular}


References Table S1.

Bárbara, I., Choi, H. G., Secilla, A., Díaz-Tapia, P., Gorostiaga, J. M., Seo, T. K., Jung, M. Y. \& Berecibar, E. 2013. Lampisiphonia iberica gen. et sp. nov. (Ceramiales, Rhodophyta) based on morphology and molecular evidence. Phycologia 52:137-55.

Bustamante, B.E., Won, B.Y. \& Cho, T.O. (2012a). Neosiphonia ramirezii sp. nov. (Rhodomelaceae, Rhodophyta) from Peru. Algae. Algae 27: 79-82.

Bustamante, D.E., Won, B.Y., Ramírez, M.E. \& Cho, T.O. (2012b). Neosiphonia peruviensis sp. nov. (Rhodomelacea, Rhodophyta) from the Pacific coast of South America. Botanica Marina 55: 359-366.

Bustamante, D.E., Won, B.Y. \& Cho, T.O. (2013). Neosiphonia baliana sp. nov. and N. silvae sp. nov. (Rhodomelaceae, Rhodophyta) from Bali, Indonesia. Botanica Marina 56: 515-524.

Bustamante, D.E., Won, B.Y. \& Cho, T.O. (2015). Polysiphonia freshwateri sp. nov. and Polysiphonia koreana sp. nov.: two new species of Polysiphonia (Rhodomelaceae, Rhodophyta) from Korea. European Journal of Phycology 50: 330-342.

Carlile, A.L. (2009). Molecular systematics of North Pacific Ceramiaceae (Rhodophyta): Phylogeny, taxonomy, and phylogeography. PhD, University of Washington. 
Choi, H. G., Kim, M. S., Guiry, M. D. \& Saunders, G. W. 2001. Phylogenetic relationships of Polysiphonia (Rhodomelaceae, Rhodophyta) and its relatives based on anatomical and nuclear small-subunit rDNA sequence data. Canadian Journal of Botany 79:1465-76.

D'Archino, R., Neill, K. \& Nelson, W. A. 2013. Recognition and distribution of Polysiphonia morrowii (Rhodomelaceae, Rhodophyta) in New Zealand Botanica Marina 56:41-47.

Fujii, M. T., Guimarâes, S. M. P. D. B., Gurgel, C. F. D. \& Fredericq, S. 2006. Characterization and phylogenetic affinities of the red alga Chondrophycus flagelliferus (Rhodomelaceae, Ceramiales) from Brazil on the basis of morphological and molecular evidence. Phycologia 45:432-41.

Kim, B. \& Kim, M.S. (2014). Three new species of Polysiphonia sensu lato (Rhodophyta) based on the morphology and molecular evidence. Algae 29: 183-195.

Kim, M. S. \& Yang, E. C. 2006. Taxonomy and phylogeny of Neosiphonia japonica (Rhodomelaceae, Rhodophyta) Based on rbcL and cpeA/B Gene Sequences. Algae 21:287-94.

Kim, M.-S., Chan Yang, E., Mansilla, A. \& Min Boo, S. (2004). Recent introduction of Polysiphonia morrowii (Ceramiales, Rhodophyta) to Punta Arenas, Chile . Botanica Marina 47: 389-394. 
Kim, M. S., Kim, S. Y. \& Nelson, W. A. (2010). Symphyocladia lithophylla sp.nov. (Rhodomelaceae, Ceramiales), a new Korean red algal species based on morphology and $r b c \mathrm{~L}$ sequences. Botanica Marina 53:233-41.

Lam, W. D., García-Fernández, M. E., Aboal, M. \& Vis, M. L. 2013. Polysiphonia subtilissima (Ceramiales, Rhodophyta) from freshwater habitats in North America and Europe is confirmed as conspecific with marine collections. Phycologia 52:156-60.

Mamoozadeh, N. R. \& Freshwater, D. W. 2011. Taxonomic notes on Caribbean Neosiphonia and Polysiphonia (Ceramiales, Florideophyceae): five species from Florida, USA and Mexico. Botanica Marina 54:269-92.

McIvor, L., Maggs, C. A., Provan, J. \& Stanhope, M. J. 2001. rbcL sequences reveal multiple cryptic introductions of the Japanese red alga Polysiphonia harveyi. Molecular Ecology 10:911-19.

Mamoozadeh, N. R. \& Freshwater, D. W. 2012. Polysiphonia sensu lato (Ceramiales, Florideophyceae) species of Caribbean Panama including Polysiphonia lobophoralis sp. nov. and Polysiphonia nuda sp. nov . Botanica Marina 55:317-347.

Muangmai, N., Yamagishi, Y., Maneekat, S \& Kaewsuralikhit, C. (2014). The new species Neosiphonia thailandica sp. nov. (Rhodomelaceae, Rhodophyta) from the Gulf of Thailand. Botanica Marina 57: 459-467

Phillips, L. E., Choi, H. G., Saunders, G. W. \& Kraft, G. T. 2000. The morphology, taxonomy and molecular phylogeny of Heterocladia and Trigenea (Rhodomelaceae, Rhodophyta), with delineation of the little known tribe Heterocladieae. Journal of Phycology 36:199-219. 
Savoie, A.M. \& Saunders, G.W. (2016). A molecular phylogenetic and DNA barcode assessment of the tribe Pterosiphonieae (Ceramiales, Rhodophyta) emphasizing the Northeast Pacific. Botany 94: 917-939.

Stuercke, B. \& Freshwater, D. W. (2008). Consistency of morphological characters used to delimit Polysiphonia sensu lato species (Ceramiales, Florideophyceae): analyses of North Carolina, USA specimens. Phycologia 47:541-59.

Stuercke, B. \& Freshwater, D. W. 2010. Two new species of Polysiphonia (Ceramiales, Florideophyceae) from the western Atlantic. Botanica Marina 53:301-11.

Yang, E.C., Boo, S.B, Bhattacharya, D., Saunders, G.W., Knoll, A.H., Fredericq, S., Graf, L. \& Yoon, H.S. (2016). Divergence time estimates and the evolution of major lineages in the florideophyte red algae. Scientific Reports 6: 21361.

Zuccarello, G.C., Moon, D. \& Goff, L.J. (2004). A phylogenetic study of parasitic genera placed in the family Choreocolacaceae (Rhodophyta). Journal of Phycology 40: 937-945. 
Table S2. List of herbarium specimens examined for comparison with Melanothamnus species

\begin{tabular}{|l|l|l|}
\hline Species & Herbarium & Code \\
\hline Lophosiphonia mexicana E.Y.Dawson & US & EYD430 (66781) \\
\hline Polysiphonia beaudettei Hollenberg & US & EYD21379 (5219) \\
\hline Polysiphonia concinna Hollenberg & US & GJH2015 (61210) \\
\hline $\begin{array}{l}\text { Polysiphonia eastwoodae Setchell \& } \\
\text { N.L.Gardner }\end{array}$ & US & 55 (66788) \\
\hline Polysiphonia gorgoniae Harvey & TCD & TCD0012804 \\
\hline Polysiphonia harlandii Harvey & TCD & TCD0011955 \\
\hline $\begin{array}{l}\text { Polysiphonia inconspicua (P. confusa } \\
\text { Hollenberg) }\end{array}$ & US & GJH3285 (61222) \\
\hline $\begin{array}{l}\text { Polysiphonia johnstonii Setchell \& } \\
\text { N.L.Gardner }\end{array}$ & US & 110 (66795) \\
\hline $\begin{array}{l}\text { Polysiphonia poko Hollenberg } \\
\text { Hollenberg }\end{array}$ & US & GJH.65-82.6 (61243) \\
\hline Polysiphonia poko var longii & US & 2709.1 (61230) \\
\hline Polysiphonia profunda Hollenberg & US & MSD19116AI1 (61231) \\
\hline Polysiphonia rubrorhiza Hollenberg & US & $18740 D(48527)$ \\
\hline
\end{tabular}




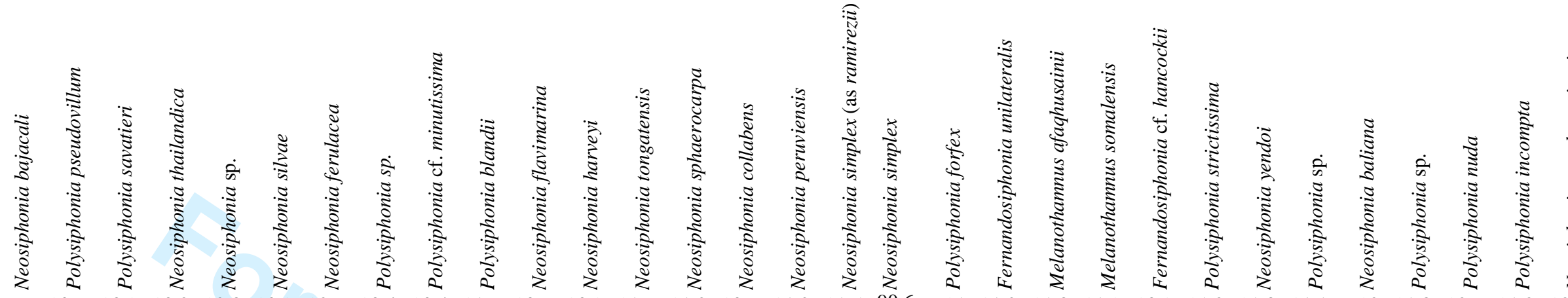

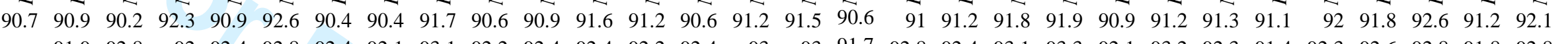

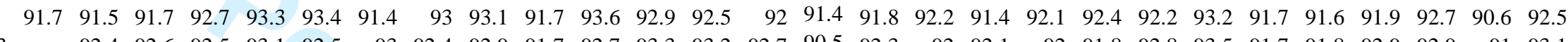

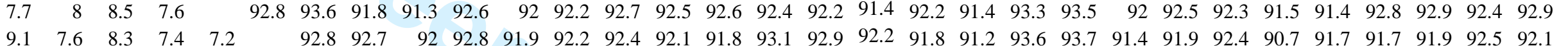

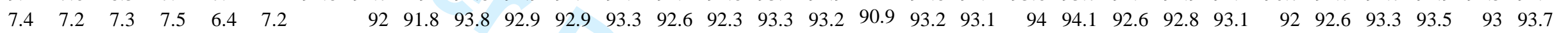
$\begin{array}{llllllllllllllllllllllllllllll}9.6 & 7.6 & 6.7 & 6.9 & 8.2 & 7.3 & 8 & 96.5 & 92 & 92.7 & 93.5 & 92.2 & 94 & 94.3 & 94 & 93.5 & 91.5 & 92.6 & 92.3 & 91.6 & 92.5 & 92.7 & 92.6 & 93.3 & 92 & 93.1 & 92.9 & 92.5 & 91.8 & 93.8\end{array}$

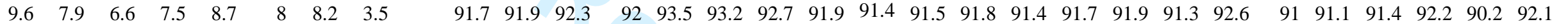

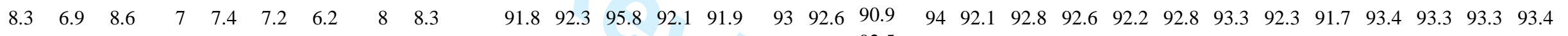

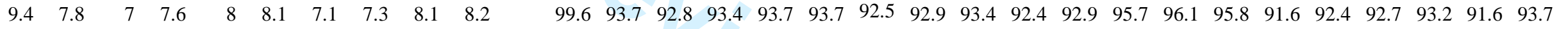

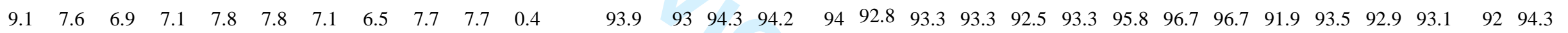

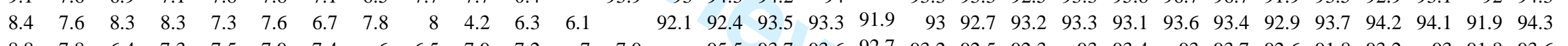

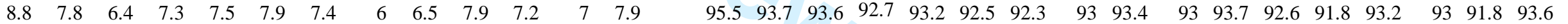

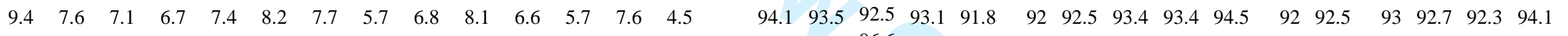

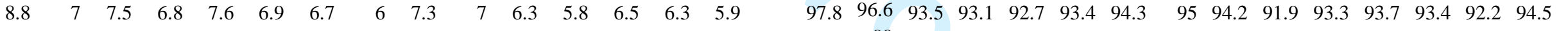

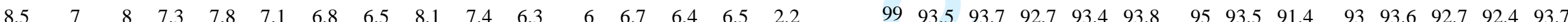
$\begin{array}{llllllllllllllllllllllllllllll}9.4 & 8.3 & 8.6 & 9.5 & 8.6 & 7.8 & 8.1 & 8.5 & 8.6 & 9.1 & 7.5 & 7.2 & 8.1 & 7.3 & 7.5 & 3.4 & 1 & 92.2 & 92.7 & 91.7 & 92.5 & 92.2 & 93.7 & 92.1 & 89.9 & 91.1 & 91.8 & 91.7 & 92.1 & 91.7\end{array}$

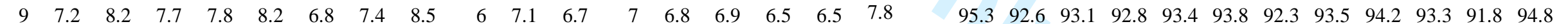

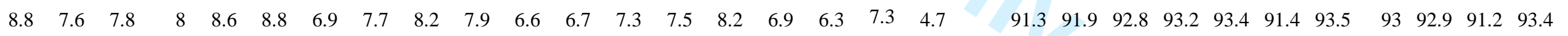
$\begin{array}{lllllllllllllllllllllllllllllll}8.2 & 6.9 & 8.6 & 7.9 & 6.7 & 6.4 & 6 & 8.4 & 8.6 & 7.2 & 7.6 & 7.5 & 6.8 & 7.7 & 8 & 7.3 & 7.3 & 8.3 & 7.4 & 8.7 & 98.6 & 91.9 & 92.7 & 92.4 & 91.6 & 92.9 & 93.7 & 93.2 & 93.1 & 93.3\end{array}$

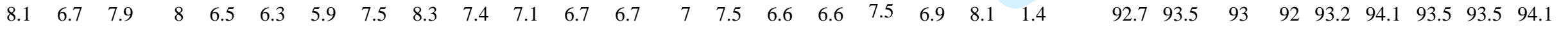
$\begin{array}{lllllllllllllllllllllllllllllll}9.1 & 7.9 & 7.6 & 8.2 & 8 & 8.6 & 7.4 & 7.3 & 8.1 & 7.8 & 4.3 & 4.2 & 6.9 & 6.6 & 6.6 & 5.7 & 6.2 & 7.8 & 7.2 & 7.2 & 8.1 & 7.3 & 95.5 & 95.3 & 91.7 & 92.5 & 93 & 93 & 91.2 & 93.4\end{array}$

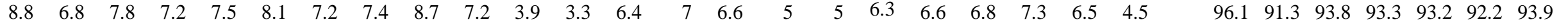
$\begin{array}{llllllllllllllllllllllllllllll}8.7 & 7.7 & 6.8 & 6.5 & 7.7 & 7.6 & 6.9 & 6.7 & 7.4 & 6.7 & 4.2 & 3.3 & 6.6 & 6.3 & 5.5 & 5.8 & 6.5 & 7.9 & 6.2 & 6.6 & 7.6 & 7 & 4.7 & 3.9 & 91.5 & 93.3 & 92.7 & 93.2 & 92.5 & 94.1\end{array}$ $\begin{array}{rllllllllllllllllllllllllllllll}8.9 & 8.6 & 8.3 & 8.3 & 8.5 & 9.3 & 8 & 8 & 9 & 7.7 & 8.4 & 8.1 & 7.1 & 7.4 & 8 & 8.1 & 8.6 & 10.1 & 7.7 & 8.6 & 8.4 & 8 & 8.3 & 8.7 & 8.5 & & 93.8 & 95.8 & 94.5 & 90.3 & 95.3\end{array}$ $\begin{array}{lllllllllllllllllllllllllllllll}8 & 7.7 & 8.4 & 8.2 & 8.6 & 8.3 & 7.4 & 6.9 & 8.9 & 8.3 & 7.6 & 6.5 & 6.3 & 8.2 & 7.5 & 6.7 & 7 & 8.9 & 6.5 & 6.5 & 7.1 & 6.8 & 7.5 & 6.2 & 6.7 & 6.2 & 95.6 & 97.4 & 91.4 & 96\end{array}$ $\begin{array}{rrrrrrrrrrrrrrrrrrrrrrrrrrrrrrrr}8.2 & 7.4 & 8.1 & 7.1 & 7.2 & 8.3 & 6.7 & 7.1 & 8.6 & 6.6 & 7.3 & 7.1 & 5.8 & 6.8 & 7 & 6.3 & 6.4 & 8.2 & 5.8 & 7 & 6.3 & 5.9 & 7 & 6.7 & 7.3 & 4.2 & 4.4 & & 96 & 92 & 97.9\end{array}$

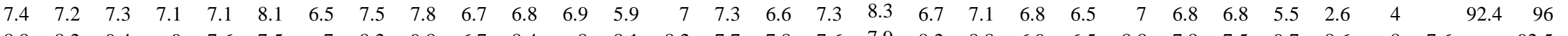
$\begin{array}{rrrrrrrrrrrrrrrrrrrrrrrrrrrrrrr}8.8 & 8.2 & 9.4 & 9 & 7.6 & 7.5 & 7 & 8.2 & 9.8 & 6.7 & 8.4 & 8 & 8.1 & 8.2 & 7.7 & 7.8 & 7.6 & 7.9 & 8.2 & 8.8 & 6.9 & 6.5 & 8.8 & 7.8 & 7.5 & 9.7 & 8.6 & 8 & 7.6 & & 92.5\end{array}$

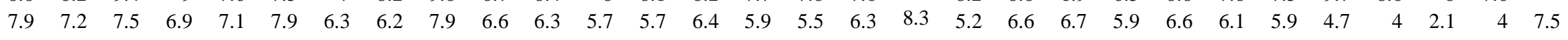

URL: http:/mc.manuscriptcentral.com/tejp Email: ejp@nhm.ac.uk 
Vertebrata lanosa

Enelittosiphonia stimpsonii Polysiphonia constricta Polysiphonia aterrima

Polysiphonia lobophoralis Boergeseniella fruticulosa Boergeseniella thuyoides

Polysiphonia tripinnato Polysiphonia furcellata Polysiphonia subulifera Brongniartella australis Ctenosiphonia hypnoides Lophosiphonia reptabunda Polysphonia simulans Polysiphonia urbana Polysiphonia foetidissima Polysiphonia isogona

Polysiphonia paniculata Polysiphonia fucoides

Brongniartella byssoides Polysiphonia nigra

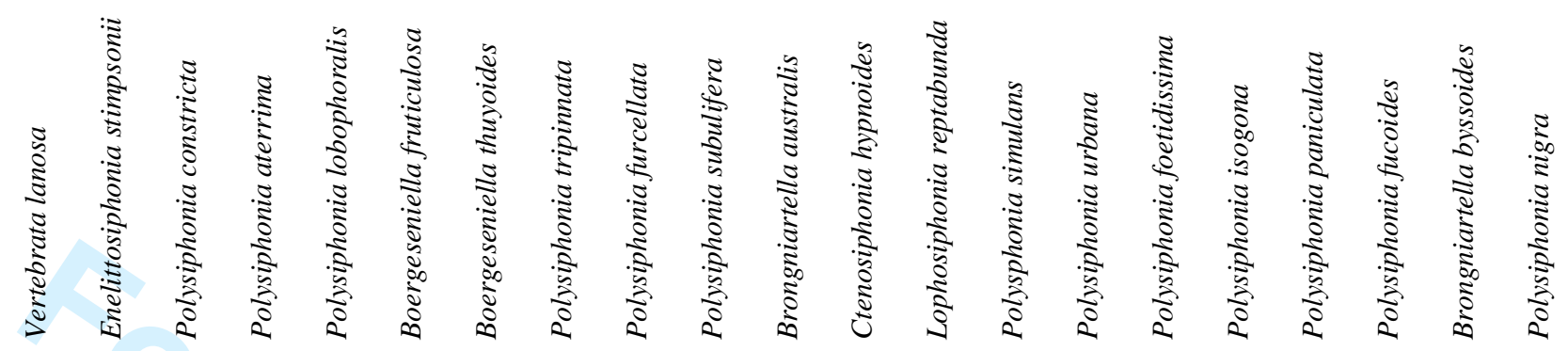

$\begin{array}{llllllllllllllllllll}89.8 & 90.3 & 91.4 & 91.7 & 90.8 & 91.2 & 91.5 & 90.5 & 90 & 91.9 & 90.2 & 89.8 & 90.9 & 91.6 & 91.9 & 91.6 & 91.4 & 91 & 91.3 & 91.2\end{array}$ $\begin{array}{llllllllllllllllllll}10.2 & 91.1 & 90.9 & 91.3 & 91.5 & 91.3 & 92.3 & 91.4 & 90.7 & 93.1 & 91.5 & 90.7 & 90.1 & 92.2 & 91.6 & 91.7 & 92.2 & 90.7 & 92.3 & 91.2\end{array}$ $\begin{array}{llllllllllllllllllll}9.7 & 8.9 & 91 & 91.2 & 91.6 & 91.8 & 91.7 & 91 & 90.7 & 92.2 & 91.1 & 90.4 & 91.3 & 92.7 & 92.5 & 92 & 91.5 & 91.1 & 91.6 & 91.4\end{array}$ $\begin{array}{llllllllllllllllllll}8.6 & 9.1 & 9 & 92.4 & 91.6 & 92.2 & 91.7 & 92.2 & 91.4 & 93.2 & 90.9 & 90.8 & 91.6 & 92.6 & 92.2 & 92.8 & 92.1 & 91.7 & 91.7 & 91.6\end{array}$ $\begin{array}{llllllllllllllllllll}8.3 & 8.7 & 8.8 & 7.6 & 91.7 & 92.7 & 90.5 & 90.9 & 90.8 & 93.4 & 90.5 & 91 & 91.6 & 91.7 & 91.5 & 91.3 & 90.7 & 90.3 & 91 & 91.1\end{array}$

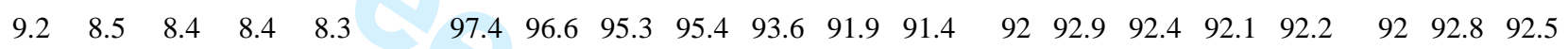
$\begin{array}{llllllllllllllllllll}8.8 & 8.7 & 8.2 & 7.8 & 7.3 & 2.6 & 96.4 & 96.1 & 95.5 & 94.6 & 92.2 & 91.5 & 92.9 & 94 & 93.5 & 93 & 92.8 & 92.4 & 93.1 & 93.3\end{array}$ $\begin{array}{llllllllllllllllllll}8.5 & 7.7 & 8.3 & 8.3 & 9.5 & 3.4 & 3.6 & 95.7 & 96.3 & 93.8 & 92.3 & 90.5 & 93.6 & 94.5 & 94.1 & 94.5 & 93.3 & 93.8 & 94.1 & 94.1\end{array}$ $\begin{array}{llllllllllllllllllll}9.5 & 8.6 & 9 & 7.8 & 9.1 & 4.7 & 3.9 & 4.3 & 94.7 & 93.4 & 91.7 & 90.5 & 92 & 93.5 & 92.9 & 92.4 & 92 & 91.5 & 92.4 & 92.2\end{array}$ $\begin{array}{llllllllllllllllllll}10 & 9.3 & 9.3 & 8.6 & 9.2 & 4.6 & 4.5 & 3.7 & 5.3 & 92.9 & 91.6 & 90 & 91.4 & 92.8 & 91.9 & 91.5 & 90.9 & 91.2 & 91.7 & 91.6\end{array}$

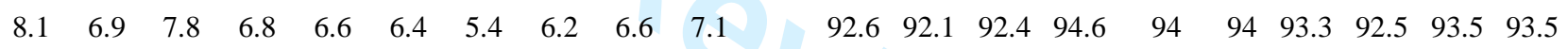

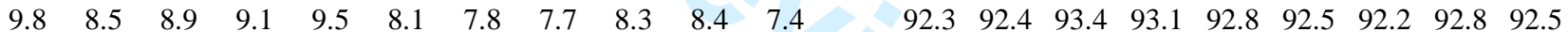
$\begin{array}{llllllllllllllllllll}10.2 & 9.3 & 9.6 & 9.2 & 9 & 8.6 & 8.5 & 9.5 & 9.5 & 10 & 7.9 & 7.7 & 92 & 92.8 & 92.2 & 92.4 & 92.2 & 91.4 & 92.1 & 92.3\end{array}$

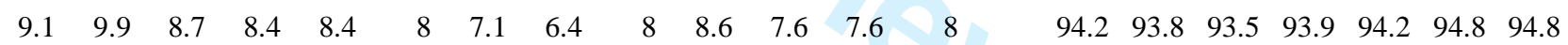
$\begin{array}{llllllllllllllllllll}8.4 & 7.8 & 7.3 & 7.4 & 8.3 & 7.1 & 6 & 5.5 & 6.5 & 7.2 & 5.4 & 6.6 & 7.2 & 5.8 & 97.9 & 97.4 & 94.7 & 94.5 & 95.3 & 95.2\end{array}$

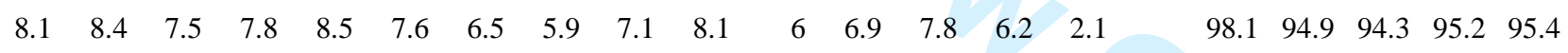
$\begin{array}{llllllllllllllllllll}8.4 & 8.3 & 8 & 7.2 & 8.7 & 7.9 & 7 & 5.5 & 7.6 & 8.5 & 6 & 7.2 & 7.6 & 6.5 & 2.6 & 1.9 & 95.1 & 94.2 & 94.8 & 95.2\end{array}$

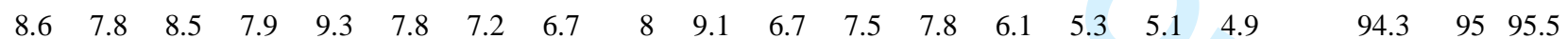
$\begin{array}{llllllllllllllllllll}9 & 9.3 & 8.9 & 8.3 & 9.7 & 8 & 7.6 & 6.2 & 8.5 & 8.8 & 7.5 & 7.8 & 8.6 & 5.8 & 5.5 & 5.7 & 5.8 & 5.7 & 95.7 & 96.4\end{array}$ $\begin{array}{llllllllllllllllllll}8.7 & 7.7 & 8.4 & 8.3 & 9 & 7.2 & 6.9 & 5.9 & 7.6 & 8.3 & 6.5 & 7.2 & 7.9 & 5.2 & 4.7 & 4.8 & 5.2 & 5 & 4.3 & 96.5\end{array}$ $\begin{array}{llllllllllllllllllll}8.8 & 8.8 & 8.6 & 8.4 & 8.9 & 7.5 & 6.7 & 5.9 & 7.8 & 8.4 & 6.5 & 7.5 & 7.7 & 5.2 & 4.8 & 4.6 & 4.8 & 4.5 & 3.6 & 3.5\end{array}$ 


\section{European Journal of Phycology Spyridia filamentosa DQ787579

Callithamnion consanguineum DQ78asge 108 of 109

Phycodrys rubens DQ787583

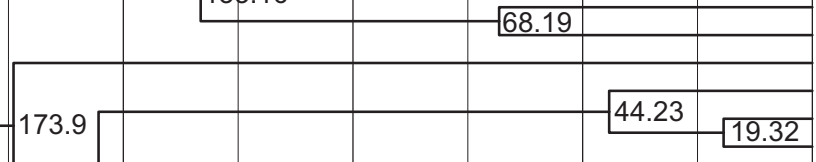
Chondrophycus intermedius DQ787585

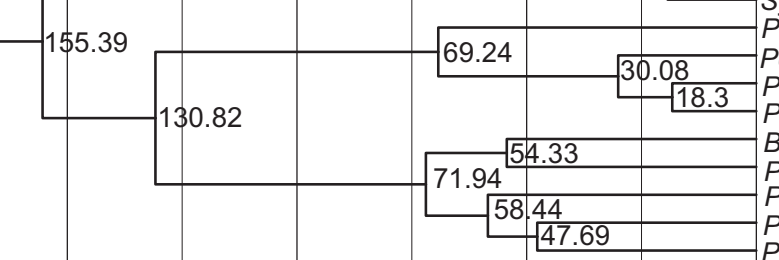

Symphyocladia lithophila GQ867078 Symphyocladia linearis JX828158 Symphyocladia latiuscula GQ867072 Polysiphonia kapraunii EU492920

Polysiphonia stricta JX828151 Polysiphonia pacifica AY958162 Bryocladia cuspidata AF259498 Polysiphonia scopulorum JX828149

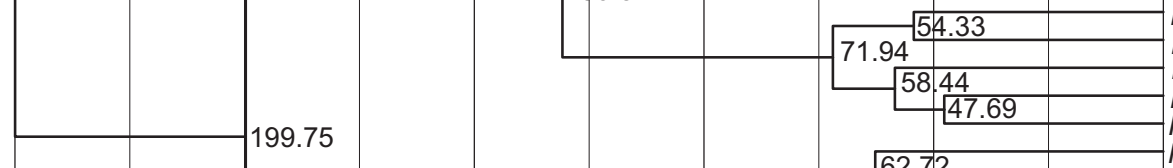
Polysiphonia freshwateri KJ957812 Polysiphonia subtilissima JX294918 Polysiphonia atlantica JX828141 Polysiphonia sertularioides HM573547

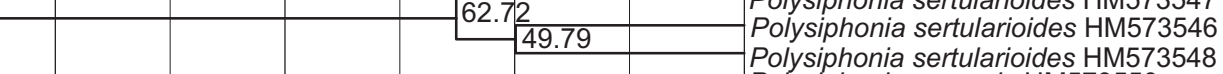
Polysiphonia sertularioides anomala HM573550

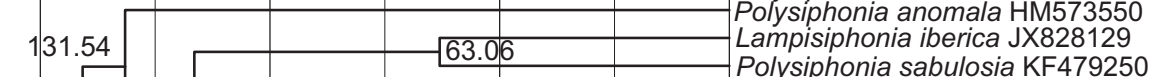

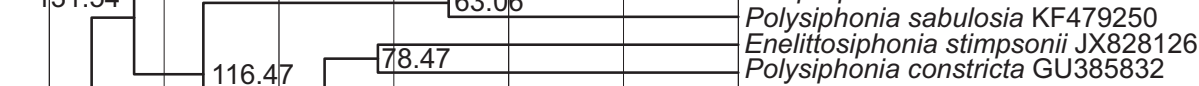

164.77

90.0764 .48 Polysiphonia constricta GU385832

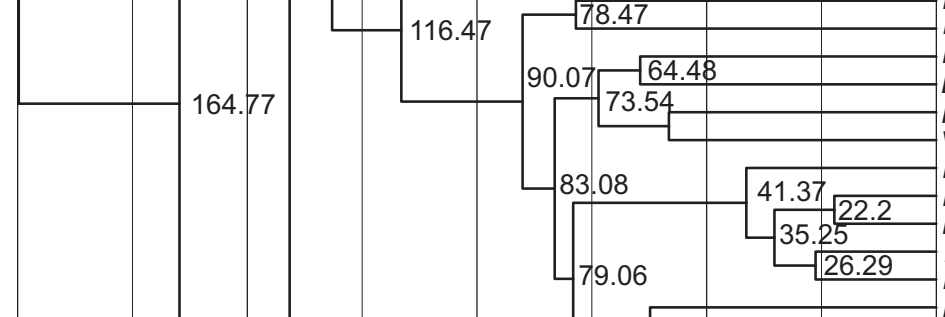

Polysiphonia aterrima GU385831

Brongniartella australis KX499546

Polysiphonia lobophoralis HM573551

Vertebrata lanosa EU492914

Polysiphonia furcellata KX499559

Boergeseniella thuyoides JX828125

140.79

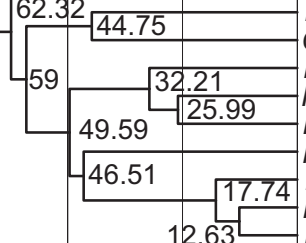

1263

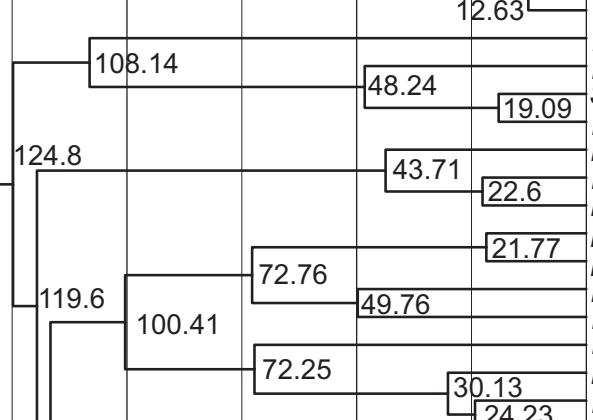
Polysiphonia subulifera KX499564 Polysiphonia tripinnata KX499566

Polysiphonia ceramiiformis KX499568 Lophosiphonia reptabunda KX499554 Ctenosiphonia hypnoides KX499547 Brongniartella byssoides DQ787584

Polysiphonia nigra JX828164

Polysiphonia fucoides JX828163 Polysiphonia paniculata AY396040 Polysiphonia urbana KX499567 Polysiphonia isogona HM573578 Polysiphonia foetidissima JQ653284 Polysiphonia sp. KX499569 Polysiphonia sp. HM573576

Streblocladia glomerulata KX499569 Polysiphonia muelleriana AY588412

Neosiphonia echinata HM573559 Polysiphonia binneyi HM573555

Polysiphonia havanensis HM573554

Polysiphonia virgata JX828152

Polysiphonia denudata JX828143 Polysiphonia elongella AF342913 Polysiphonia elongata JX828162 Polysiphonia fibrata AF342915 Polysiphonia fibrillosa AF342912 \begin{tabular}{|l|l}
116.66 & $\begin{array}{r}\text { Polysiphonia brodiei AF342916 } \\
\text { Leptosiphonia schousboei JX828133 } \\
\text { Polysiphonia homoia HM573553 }\end{array}$
\end{tabular} \begin{tabular}{|l|r|r|r}
\hline & & & \\
& & & \\
Polysiphonia homoia HM573553 \\
Polysiphonia morroides KF479257
\end{tabular}

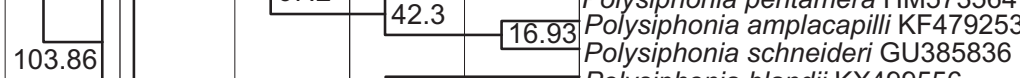
\begin{tabular}{|l|l|l|l|}
103.86 & & & Polysiphonia blandii KX499556 \\
\hline & 42.16 & Neosiphonia tongatensis HM573570
\end{tabular}

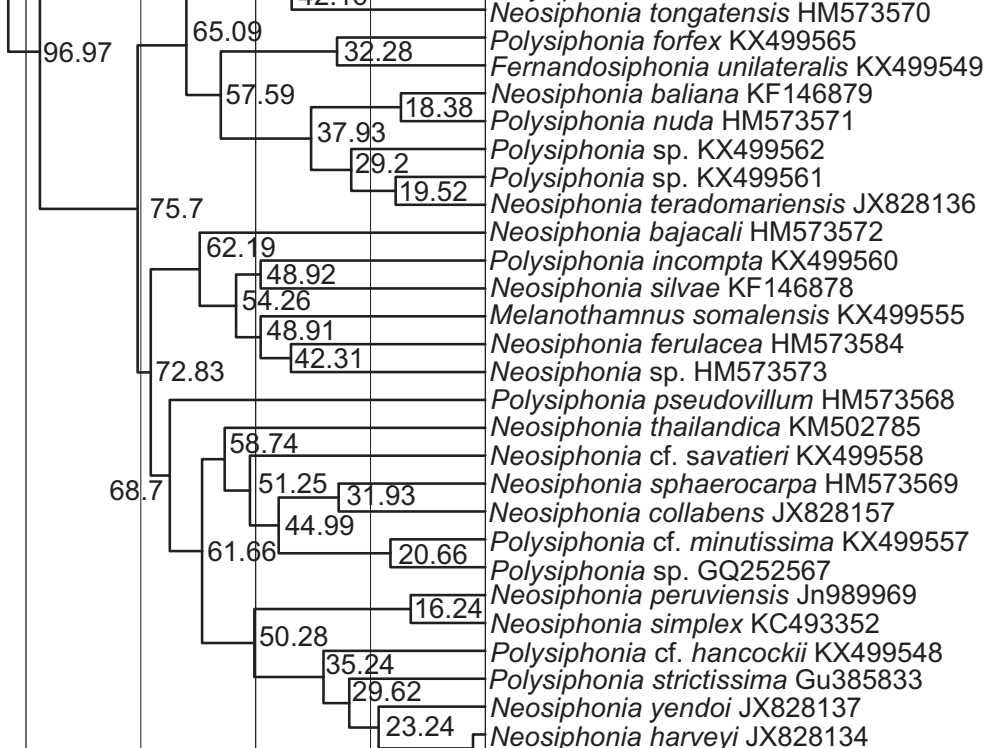




\section{page 109 of 109}

European Journal of Phycology

Spyridia filamentosa DQ787579 Seirospora interrupta DQ110903 \begin{tabular}{|l|l|l|l|l|l|l}
291.88 & & & & & & \\
\hline
\end{tabular}

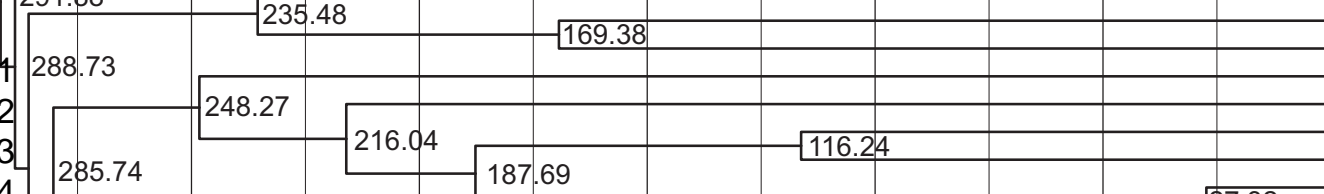
Centroceras clavulatum AY295175 Griffithsia corallinoides AY295164 Ptilota gunneri DQ787575

Phycodrys rubens DQ787583

Delesseria serrulata DQ787582

Dasysiphonia oldensis DQ787581

Dasya collabens DQ787580

Chondrophycus intermedius DQ787585

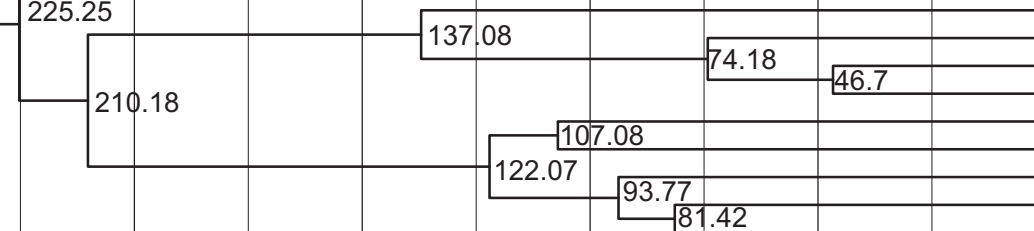

27.32

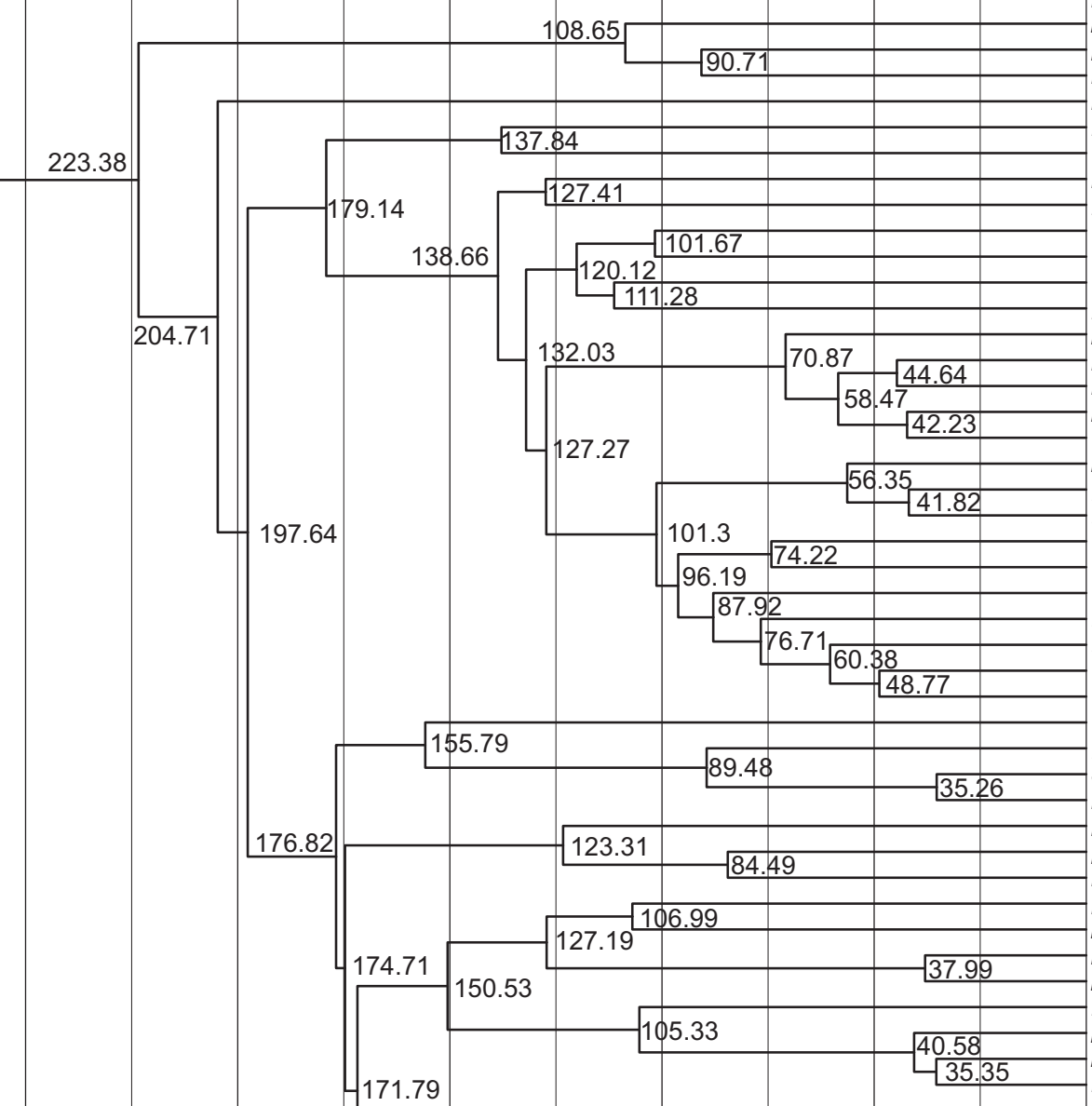

Symphyocladia lithophila GQ867078

Symphyocladia linearis JX828158

Symphyocladia latiuscula GQ867072

Polysiphonia kapraunii EU492920

Polysiphonia morrowii KC152488

Polysiphonia stricta JX828151

Polysiphonia pacifica AY958162

Polysiphonia scopulorum JX828149

Bryocladia cuspidata AF259498

Polysiphonia freshwateri KJ957812

Polysiphonia subtilissima JX294918

Polysiphonia atlantica JX828141

Polysiphonia sertularioides HM573547

Polysiphonia sertularioides HM573546

Polysiphonia sertularioides HM573548 Polysiphonia anomala HM573550

Polysiphonia sabulosia KF479250 Lampisiphonia iberica JX828129

Polysiphonia constricta GU385832

Enelittosiphonia stimpsonii JX828126

Vertebrata lanosa EU492914

Polysiphonia lobophoralis HM573551

Polysiphonia aterrima GU385831

Brongniartella australis KX499546

Polysiphonia furcellata KX499559

Polysiphonia tripinnata KX499566

Polysiphonia subulifera KX499564

Boergeseniella thuyoides JX828125

Boergeseniella fruticulosa JX828161

Polysiphonia urbana KX499567

Polysiphonia isogona HM573578

Polysiphonia foetidissima JQ653284

Lophosiphonia reptabunda KX499554

Ctenosiphonia hypnoides KX499547

Polysiphonia paniculata AY396040

Polysiphonia ceramiiformis KX499568

Brongniartella byssoides DQ787584

Polysiphonia nigra JX828164

Polysiphonia fucoides JX828163

Polysiphonia sp. KX499569

Polysiphonia sp. HM573576

Streblocladia glomerulata KX499569

Polysiphonia muelleriana AY588412

Neosiphonia echinata HM573559

Polysiphonia havanensis HM573554

Polysiphonia binneyi HM573555

Polysiphonia elongella AF342913

Polysiphonia elongata JX828162

Polysiphonia virgata JX828152

Polysiphonia denudata JX828143

Polysiphonia fibrata AF342915

Polysiphonia fibrillosa AF342912

Polysiphonia brodiei AF342916

Leptosiphonia schousboei JX828133

Polysiphonia homoia HM573553

Polysiphonia morroides KF479257

Polysiphonia pentamera HM573564

Polysiphonia schneideri GU385836

Polysiphonia amplacapilli KF479253

Neosiphonia tongatensis HM573570

156.25 42.19

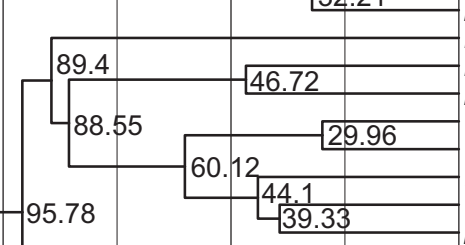

Polysiphonia forfex KX499565

Fernandosiphonia unilateralis KX499549

Polysiphonia nuda HM573571

Neosiphonia baliana KF146879

Neosiphonia teradomariensis JX828136

Polysiphonia sp. KX499562

Polysiphonia sp. KX499561

Polysiphonia blandii KX499556

Neosiphonia bajacali HM573572

Polysiphonia incompta KX499560

Polysiphonia incompta KX49956

Melanothamnus somalensis KX499555

Neosiphonia sp. HM573573

Neosiphonia ferulacea HM573584

Polysiphonia pseudovillum HM573568

Neosiphonia thailandica KM502785

Neosiphonia cf. savatieri KX499558

84.07

Polysiphonia sp. GQ252567

Polysiphonia cf. minutissima KX499557

Neosiphonia collabens JX828157

Neosiphonia sphaerocarpa HM573569

23.67 Neosiphonia simplex KC493352

Polysiphonia cf. hancockii KX499548

Polysiphonia strictissima Gu385833

Neosiphonia yendoi JX828137

Neosiphonia harveyi JX828134 